Universidad de Lima

Escuela de Posgrado

Maestría en Derecho Empresarial

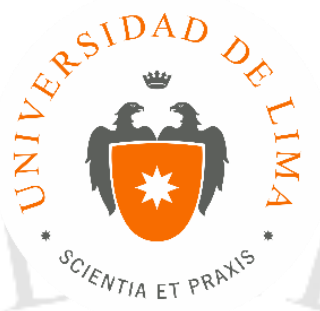

\title{
ROL DE LA CONTRALORÍA GENERAL DE LA REPÚBLICA EN PROYECTOS DE INVERSIÓN MEDIANTE ASOCIACIONES PÚBLICO PRIVADAS (APP)
}

Trabajo de investigación para optar el Grado Académico de Maestro en

Derecho Empresarial

Kattia Dalinda Tirado Arias

Código 19994625

Asesor:

Desirée Orsini Wisoztki

Lima - Perú

Julio de 2017 


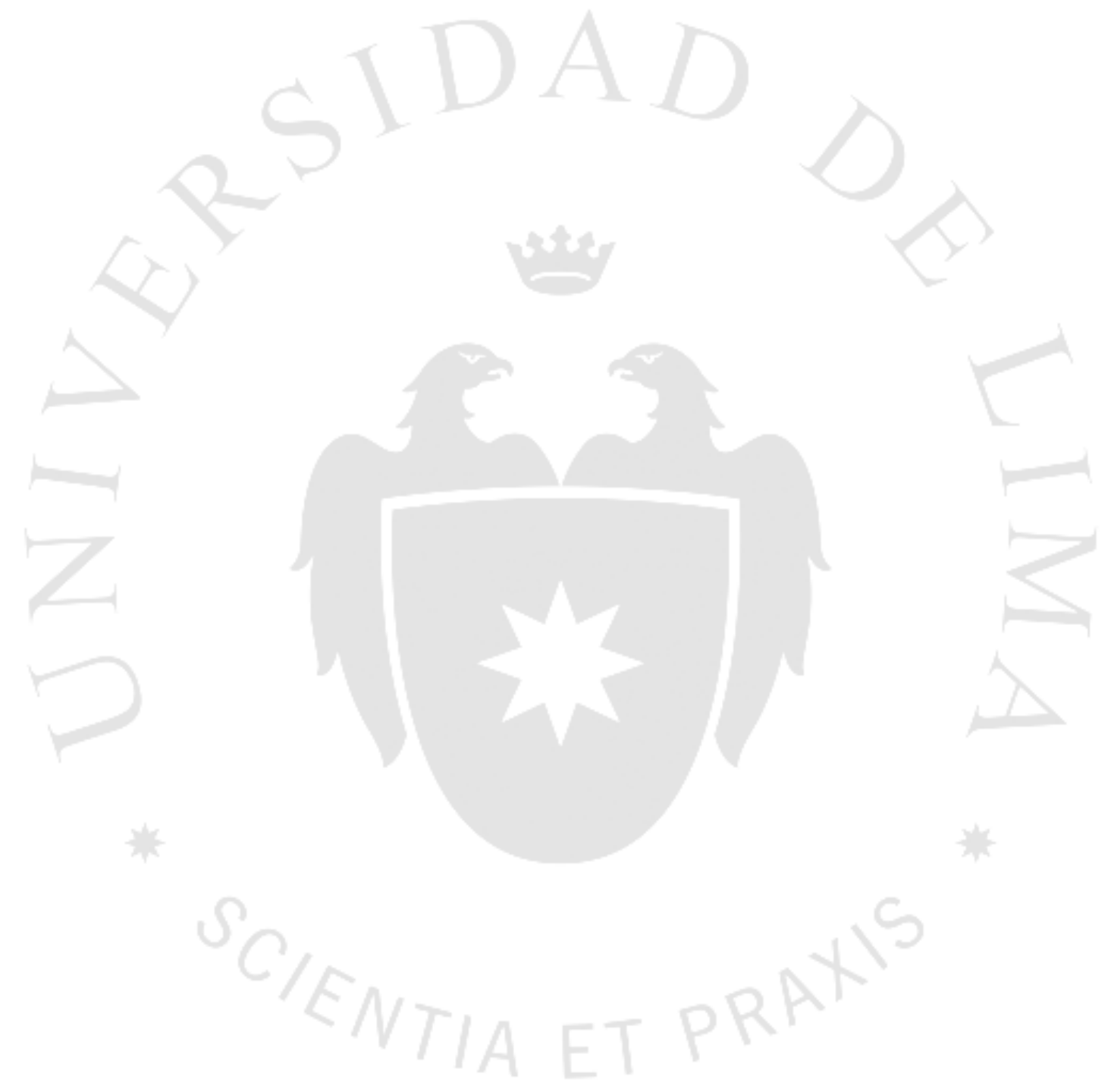




\section{ROL DE LA CONTRALORÍA GENERAL DE}

LA REPÚBLICA EN PROYECTOS DE INVERSIÓN MEDIANTE ASOCIACIONES PÚBLICO PRIVADAS (APP) 


\section{TABLA DE CONTENIDO}

INTRODUCCIÓN

CAPÍTULO I: LAS ASOCIACIONES PÚBLICO - PRIVADAS (APP) EN EL PERÚ

Y SU IMPLEMENTACIÓN PARA LOGRAR EFICIENCIA EN LOS PROYECTOS

DE INVERSIÓN.

1.1 ¿Qué es una Asociación Público Privada - APP?

4

1.2 Rol del Estado Peruano Moderno: Política Nacional de Modernización de

la Gestión Pública al 2021 ........................................................ 6

1.2.1. Planeamiento de Estado. ........................................................ 111

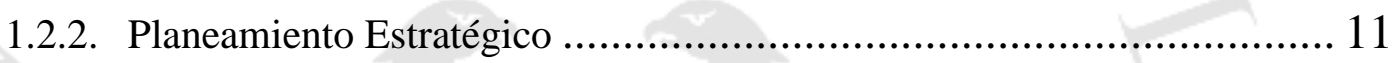

1.2.3. Presupuesto para resultados ........................................... 12

1.2.4. Gestión por resultados ................................................ 15

1.2.5. Servicio civil meritocrático ................................................. 166

1.2.6. Seguimiento, evaluación y gestión del conocimiento. ...................... 16

1.3 Marco normativo de las APP y principales cambios .......................... 17

1.3.1 Principales cambios en la normativa de APP ................................ 322

1.3.2 Principales actores involucrados en el Sistema Nacional de promoción de la inversión privada ......................................................... 377

1.4 Importancia de la implementación de una APP y por qué seguir apostando por ellas? ................................................................... 41

1.4.1 Análisis de las bondades de una APP. ..................................... 444

1.4.2 Problemática o barreras para la ejecución de APP - Renegociaciones ..... 477

1.4.3 Resultados adversos en casos de coyuntura. ................................. 51 


\section{CAPÍTULO II: ROL DE LA CONTRALORÍA GENERAL DE LA REPÚBLICA EN PROYECTOS DE INVERSIÓN A TRAVÉS DE APP}

2.1 El Control Gubernamental y el rol de la Contraloría General de la República

2.1.1 El Control previo como un facilitador en los procesos de promoción de la inversión pública.

2.2 Normas que regulan la intervención de la Contraloría General de la República en el proceso de promoción de la inversión privada

2.2.1 Algunas alertas de normativa de carácter internacional 699

\section{CAPÍTULO III: PROPUESTA NORMATIVA DE PARTICIPACIÓN DE LA} CONTRALORÍA GENERAL DE LA REPÚBLICA A TRAVÉS DEL CONTROL PREVIO EN LAS MODIFICACIONES CONTRACTUALES EN LOS

3.1 Problemas en la conclusión de proyectos de inversión por renegociaciones contractuales producto de la implementación del modelo de APP o por una mala gestión?

3.1.1 Propuesta normativa que busca el fortalecimiento del control previo para que intervenga en las modificaciones contractuales, como un facilitador. 766

3.1.2 Proyecto de ley de propuesta normativa en el Congreso de la República. 80

3.2 Caso de Estudio: Contrato de Concesión para el nuevo Aeropuerto de Chinchero-Cusco. 


\section{ÍNDICE DE TABLAS}

Tabla 1. 1 Deficiencias de la Gestión Pública en el Perú

Tabla 1.2. Detalle de la normativa de APP y precisiones en torno a modificaciones contractuales.

Tabla 1.3. Principales cambios que se han dado con la nueva legislación de APP .333

Tabla 1.4. Principales bondades de las APP 455

Tabla 1.5. Diferencia entre el Contrato de Obra Pública y el Contrato de Concesión (APP) 477

Tabla 1.6. Lista de proyectos en ejecución bajo la modalidad de APP, sector Transportes y Comunicaciones .50

Tabla 1.7. Principales conceptos de las modificaciones contractuales efectuadas con el Concesionario del Aeropuerto Jorge Chávez

Tabla 2.1. Entidades sujetas al control gubernamental de CGR .60

Tabla 2.2. Tipos de servicios de control gubernamental. 622

Tabla 2.3. Cuándo se debe presentar la solicitud para la emisión de un Informe previo?..... 666

Tabla 2.4. Lineamientos internacionales para la mejor práctica en la auditoría de una APP. 


\section{ÍNDICE DE FIGURAS}

Figura 1.1. Cadena de valor durante el proceso de producción de infraestructura y servicios públicos a través de APP.

Figura 1.2. Marco legal para la promoción de la inversión Privada en el Perú 18

Figura 1.3. Principales actores involucrados en el Sistema Nacional de promoción de la Inversión Privada. 388

Figura 1.4. Proyectos APP adjudicados, $2006-2016^{1 /}$

Figura 1.5. Línea de tiempo del Contrato de Concesión del Aeropuerto Internacional Jorge Chávez y modificaciones contractuales 533

Figura 3.6 Emisión del informe previo de la Contraloría sobre operaciones, fianzas o avales que comprometan al Estado ....................................... 78

Figura 3.7. Esquema del Contrato original de Chinchero.......................................... 84

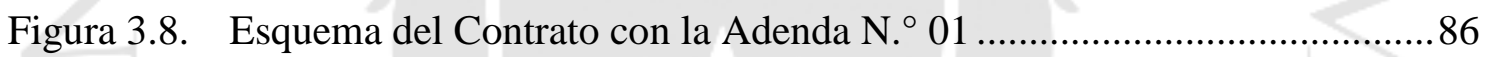




\section{ÍNDICE DE ANEXOS}

Anexo 1. Procesos Adjudicados en el Período Enero 2008 - MARZO 2017 1033 


\section{INTRODUCCIÓN}

El Estado peruano se encuentra en proceso de Modernización de la Gestión Pública y a su vez, viene impulsando la inversión privada como una respuesta a la necesidad de servicios públicos e infraestructura que no puede satisfacer; es por ello que reconoce esta facultad en los particulares mediante la modalidad de contratación de Asociación Público Privadas (APP); sin embargo, los proyectos de inversión pública no han venido otorgando los resultados esperados.

En por ello, que se desarrolla el presente trabajo de investigación, con el objeto de analizar el "rol de la Contraloría General de la República en proyectos de inversión mediante APP" y si el control preventivo puede contribuir como un facilitador en lograr la eficacia en la implementación de proyectos de inversión mediante APP en aras de generar resultados que impacten positivamente en el bienestar del ciudadano y en el desarrollo del país; asimismo, lograr recomendaciones que generen cambios efectivos en la gestión pública

Para lo cual se consideró importante en el primer capítulo, conocer y valorar la importancia de la implementación de la APP en nuestro país; por ello se revisó su conceptualización, marco normativo, así como las principales entidades que participan en el Sistema Nacional de Promoción de la Inversión Privada, entre ellas la Contraloría General de la República. Asimismo, se alertó que pese a las bondades y el valor que otorgan las APP para lograr eficiencia a los proyectos de inversión, éstas afrontan problemáticas que impiden su correcta implementación.

En el segundo capítulo, se buscó enfatizar que sí es posible lograr eficacia del Estado en los proyectos de inversión mediante la implementación de APP, ello principalmente si se tiene como socio estratégico a la Contraloría General de la República, permitiéndole contribuir desde un enfoque integral y preventivo orientado a una gestión por resultados. Para lo cual se analizó el rol de la Contraloría General de la República, sus diferentes formas de intervención pero apostando por el control previo como un facilitador en los procesos de promoción de la inversión pública. 
Finalmente, el tercer capítulo da a conocer una solución frente a la problemática de falta de eficacia en la ejecución de los proyectos de inversión mediante APP. Es por ello, que se busca otorgar una propuesta normativa en donde se considerada vital "fortalecer el control previo que ejerce la Contraloría General de la República en el marco del Sistema Nacional de la Promoción de la Inversión Privada” dado que existe la necesidad de disponer de una herramienta de control previo que nos permita detectar de manera oportuna los posibles riesgos que involucren las modificaciones que se deriven de la adenda de los contratos de APP. 


\section{CAPÍTULO I: LAS ASOCIACIONES PÚBLICO - PRIVADAS (APP) EN EL PERÚ Y SU IMPLEMENTACIÓN PARA LOGRAR EFICIENCIA EN LOS PROYECTOS DE INVERSIÓN}

El presente capítulo busca ser un espacio que permita conocer y valorar la importancia de la implementación en nuestro país de las asociaciones público privadas; para lo cual se revisará su conceptualización, marco normativo, así como las principales entidades que participan en el Sistema Nacional de Promoción de la Inversión Privada, entre ellas la Contraloría General de la República. Asimismo, busca alertar que pese a las bondades y el valor que otorgan las asociaciones público privadas para lograr eficiencia a los proyectos de inversión, éstas afrontan problemáticas que impiden su correcta implementación o a su vez, se encuentran en ejecución proyectos que no son los que el país o la región más necesitan, para lo cual se analizará una muestra de proyectos que pese a los denodados esfuerzos del Estado no logran los resultados esperados. En atención a ello, se consideró importante reflejar y analizar el trabajo que de manera paralela ha venido realizando el Estado peruano desde el 2002 al declarase en proceso de Modernización de la Gestión Pública, - reconociendo su problemática y necesidad de ser un Estado efectivo, - estableciéndose como principal desafío el lograr mejorar significativamente los niveles de bienestar de la población a través de resultados que le impacten positivamente, particularmente de la más excluida de los circuitos del crecimiento económico. Esta reforma, busca dejar de ser un Estado inercial y lograr mayores niveles de eficacia en el cumplimiento de los objetivos de política, los cuales deben estar reflejados en documentos de gestión que contengan acciones que estén asociadas - en los 3 niveles de gobierno - a un propósito final no solo como gobierno sino como Estado. Ello permitirá evaluar si la labor que vienen haciendo nuestras entidades y funcionarios públicos conlleva avance e impacto positivo en el bienestar en el ciudadano; y a su vez, en la optimización en el gasto de los recursos públicos. Posteriormente, frente a la lentitud de este avance, el Estado peruano ha emitido la 
Política Nacional de Promoción de la Inversión Privada en Asociaciones Público Privadas y Proyectos en Activos, como un esfuerzo Adhoc y trasversal de política nacional, liderado por el Ministerio de Economía y Finanzas ante la ausencia de un Centro Nacional de Planeamiento Estratégico (Ceplan).

\section{1 ¿Qué es una Asociación Público Privada - APP?}

Las Asociaciones Público Privadas (APP), tienen su origen en el modelo económico que nace en el Reino Unido en 1992, mediante la iniciativa de financiamiento privado Private Finance Initiative - PFI, estableciendo desde el inicio de esta modalidad dos conceptos fundamentales: el valor por dinero y la apropiada transferencia de riesgos que la debe definir. Para que el modelo sea un éxito, debería alejarse inmediatamente de la idea de servicios más baratos, y en su lugar buscar el objetivo conocido por la Unión Europea que es "condiciones económicas más ventajosas", combinación óptima de costos durante la totalidad del ciclo de vida de un proyecto; la calidad o capacidad para satisfacer los requerimientos de los usuarios en los servicios prestados y los beneficios resultantes. Es por ello, que el Estado ha permitido que el sector privado provea servicios que habían sido tradicionalmente prestados por el sector público; y esto ha incluido no sólo el desarrollo y la operación de infraestructura, sino también el financiamiento de las inversiones necesarias para prestar servicios públicos. Formalmente HM Treasury definió el concepto de valor por Dinero como "la combinación óptima de costos durante la totalidad del ciclo de vida de un proyecto, y la calidad o capacidad para satisfacer los requerimientos de los usuarios" (Banco Interamericano de Desarrollo, 2009, pp. 9-10).

Este modelo económico británico, comenzó a difundirse a finales de los años noventa teniendo mayor auge en los últimos años, conocido como asociaciones público privadas o alianzas público privadas (APP) en donde su principal característica es la distribución y mitigación de riesgos entre las partes público (a nivel de los tres niveles de gobierno) y privado intervinientes en función a la mejor capacidad que tengan cada una de ellas para administrarlo. El escenario de globalización mundial ha influenciado notablemente el desarrollo económico social de los países que la han adoptado, frente a restricciones presupuestarias y de inversión pública que siguen existiendo. 
Con ello, se busca no solo mejorar la prestación de servicios públicos y proveer de la infraestructura que exige el país, sino también elevar los niveles de vida y bienestar de los ciudadanos a largo plazo; más si tenemos en cuenta que ello se agudiza en determinados sectores más que otros, por cuanto - como es de conocimiento - a inicios del 2017 los desastres naturales (lluvias y huaycos) azotaron a nuestro país, afectaron a diversas regiones principalmente a la zona norte, que tuvieron que ser declaradas en emergencia; con lo cual el proceso de reconstrucción viene a agravar el déficit de infraestructura y mejora de los servicios públicos que ya existía.

Las alianzas público privadas (APP), propugnan involucrar al sector privado con instituciones públicas para conseguir objetivos comunes con lo cual se conjuga objetivos estratégicos de la administración pública con intereses privados; ello ha sido fundamental para el crecimiento económico a nivel mundial; pero pese a su importancia, el concepto de APP sigue siendo complejo, sin existir una definición concreta que lo delimite, su enfoque varía en función de sus objetivos, ya sean, entre otros, aumentar la productividad de un sector, potenciar la exportación de determinados productos, crear un sistema de infraestructura, modernizar los servicios sanitarios, y/o potenciar la investigación, el desarrollo y la investigación para sectores determinados. (Casado, 2007, pp. 1-2).

Acorde a lo anterior es evidente, la importancia de este modelo económico, que ha generado un incremento de contratos bajo las asociaciones público privadas, pero se observa diferentes enfoques en su definición:

No hay una definición extensamente aceptada sobre qué significa una asociación público-privada (APP). En líneas generales, una asociación público-privada se refiere a un acuerdo entre el sector público y el sector privado en el que parte de los servicios o labores que son responsabilidad del sector público es suministrada por el sector privado bajo un claro acuerdo de objetivos compartidos para el abastecimiento del servicio público o de la infraestructura pública. (World Bank Group, Wed,2017-02-01, párr. 1)

Existe una creciente tendencia de los países a incorporar una definición de APP dentro de su regulación normativa, adecuándola a sus instituciones y particularidades legislativas (World Bank Group, Wed,2017-02-01, párr. 3). 
Actualmente, nuestro país acoge dentro de su normativa este novedoso modelo económico de APP, definiéndola de la siguiente manera:

Las Asociaciones Público Privadas -APP son modalidades de participación de la inversión privada en las que se incorpora experiencia, conocimientos, equipos, tecnología, y se distribuyen riesgos y recursos, preferentemente privados, con el objeto de crear, desarrollar, mejorar, operar o mantener infraestructura pública, proveer servicios públicos y/o proveer servicios públicos bajo los mecanismos contractuales permitidos en el marco legal vigente. Los contratos de Asociaciones público privadas son de largo plazo, en los cuales debe existir una adecuada distribución de riesgos entre las partes, de manera que los riesgos sean asignados a aquella parte con mayores capacidades para administrarlos, considerando el perfil del proyecto. Asimismo, en todas las fases de desarrollo se debe contemplar el principio de valor por dinero buscando la combinación óptima entre los costos y la calidad del servicio público ofrecido a los usuarios a lo largo de la vida del proyecto (Decreto Legislativo N. ${ }^{\circ} 1224$, 2015, p.5)

Por lo que se advierte que el Perú ofrece un marco legal para las asociaciones públicoprivada que busca motivar la inversión extranjera, en aras de que se constituya en un mecanismo que permita al Estado evitar o diferir el gasto que existe por el déficit en infraestructura y mejora de servicios públicos pero sin renunciar a los beneficios o bondades que conlleva su implementación.

\subsection{Rol del Estado Peruano Moderno: Política Nacional de Modernización de la Gestión Pública al 2021}

Resulta importante tener en cuenta que el Estado Peruano desde el período 2002 se declaró en proceso de modernización de la Gestión Pública, en sus diferentes instancias, dependencias, entidades, organizaciones y procedimientos; con la finalidad fundamental de mayores niveles de eficiencia del aparato estatal, de manera que logre una mejor atención a la ciudadanía, priorizando y optimizando el uso de los recursos públicos. Para ello se requiere alcanzar un Estado: i) Al servicio de la ciudadanía; ii) Con canales efectivos de participación ciudadana; iii) Descentralizado y desconcentrado; iv) 
Transparente en su gestión; v) Con servidores públicos calificados; y adecuadamente remunerados; y vi) fiscalmente equilibrados (Ley N. $\left.{ }^{\circ} 27658,2002\right)$.

Es en ese reto país, que ya han pasado más de 15 años, en donde el Estado viene promoviendo los mecanismos para lograr una adecuada democracia participativa de los ciudadanos, buscando asimismo que la gestión y el uso de los recursos públicos en la Administración Pública estén sometidos a la medición del cumplimiento de las funciones asignadas y la obtención de resultados, los cuáles debieran ser evaluados periódicamente (Ley N. $\left.{ }^{\circ} 27658,2002\right)$.

Es así que, en el período 2012, la Presidencia del Consejo de Ministros, en su calidad de rector del Proceso de Modernización, a través de la Secretaría de Gestión Pública diseñó una Estrategia de Modernización de la Gestión Pública (2012 - 2016); en donde se advierte que pese a los esfuerzos todavía sigue siendo un proceso inconcluso dado que el Estado sigue actuando de manera desarticulada e ineficiente, especialmente en la provisión de bienes y prestación de servicios públicos; por lo que se consideró que si se quiere un Estado moderno, eficiente, descentralizado, unitario, inclusivo y abierto ${ }^{1}$ debe generarse una transformación sustantiva de algunos roles básicos que ha venido desarrollando como Estado enfocándose hacia el logro de una gestión pública orientada a resultados que impacten en el bienestar del ciudadano, procurando generar igualdad de oportunidades y asegurando sobre todo, el acceso a servicios públicos de calidad, a través de la articulación de políticas e iniciativas, acompañado del uso de instrumentos y herramientas de gestión, con el fin último de

1 Decreto Supremo N. ${ }^{\circ}$ 109-2012-PCM (2012) por el cual se aprueba la Estrategia para la Modernización de la Gestión Pública, precisando que Estado moderno, eficiente, descentralizado, unitario, inclusivo y abierto, es lo siguiente:

- Moderno: Es flexible para adecuarse a las necesidades de los ciudadanos y a los cambios sociales, políticos y económicos del entorno sin perder sus objetivos esenciales.

- Eficiente: Genera el mayor valor público a través de un uso racional de los recursos con los que cuenta, buscando proveer lo que el ciudadano necesita, al menor costo posible con un estándar de calidad adecuado y en las cantidades óptimas que maximicen el bienestar social.

- Descentralizado y Unitario: Busca satisfacer las necesidades de la ciudadanía adaptando sus políticas a las diferencias según el territorio a través de gobiernos descentralizados autónomos en su ámbito de competencia y sujetos a políticas y normas nacionales que garanticen los derechos que corresponden a todos por igual.

- Inclusivo: Orienta sus acciones a que todos los ciudadanos tengan igualdad de oportunidades, buscando cerrar las brechas existentes.

- Abierto: Es transparente y accesible a los ciudadanos, fomenta la participación ciudadana y posee capacidad de respuesta a las demandas y necesidades ciudadanas y rinde cuentas. 
generar cambios en beneficio del ciudadano (Decreto Supremo N. ${ }^{\circ}$ 109-2012-PCM, 2012).

Al respecto, los esfuerzos que se han realizado por mejorar la gestión pública en el Perú son numerosos y de todo tipo, pero no necesariamente responden a una orientación estratégica, habiéndose desarrollado de una manera aislada y desarticulada, por lo que no habrían cambiado sustancialmente el desempeño global del Estado; por cuanto, entre otros, las entidades públicas nacionales, regionales y locales no muestran en general, tener las capacidades de gobierno y de gerencia suficientes para proveer con eficacia, eficiencia y transparencia más y mejores bienes, infraestructura y servicios públicos a los ciudadanos en todo el país según su necesidad, siendo que las deficiencias del Estado tienen impacto en la vida de los ciudadanos, en las actividades empresariales (competitividad), en la legitimidad de los gobiernos; y por lo tanto en el sistema democrático y en el de sus Instituciones. Dicha situación hace que la ciudadanía exija un mejor Estado, presente, activo y efectivo en todo el territorio nacional; por ello nace la política Nacional de Modernización de la Gestión Pública al 2021 (Decreto Supremo N. ${ }^{\circ}$ 004-2013-PCM, 2013).

Sin embargo, consideramos que para lograr cualquier tipo de cambio como país, es importante conocer las principales deficiencias de la gestión pública en el Perú, dado que las mismas terminan siempre incidiendo negativamente en el resultado de la gestión y en nuestro desempeño como Estado, afectando no solo en la confianza de la población en sus autoridades y Estado sino también en el bienestar del ciudadano; lo cual se detalla a continuación:

\section{Tabla 1.1}

Deficiencias de la Gestión Pública en el Perú

\begin{tabular}{|c|c|}
\hline Deficiencia & \multicolumn{1}{c|}{ Situación cómo se presenta } \\
\hline 1. Ausencia de un & • No está claro el rol que ejerce el Centro Nacional de Planeamiento \\
Sistema eficiente & Estratégico - CEPLAN ni las políticas ni objetivos prioritarios del \\
de planeamiento y & Gobierno. \\
problemas de & - Problemas en la definición de objetivos: no necesariamente recogen \\
articulación con el & demandas de la ciudadanía y las brechas que se desean cubrir no se \\
sistema de & estiman adecuadamente. \\
presupuesto & - No hay seguridad de alineamiento entre las políticas públicas \\
público & nacionales y sectoriales con las territoriales de responsabilidad de los \\
\hline
\end{tabular}




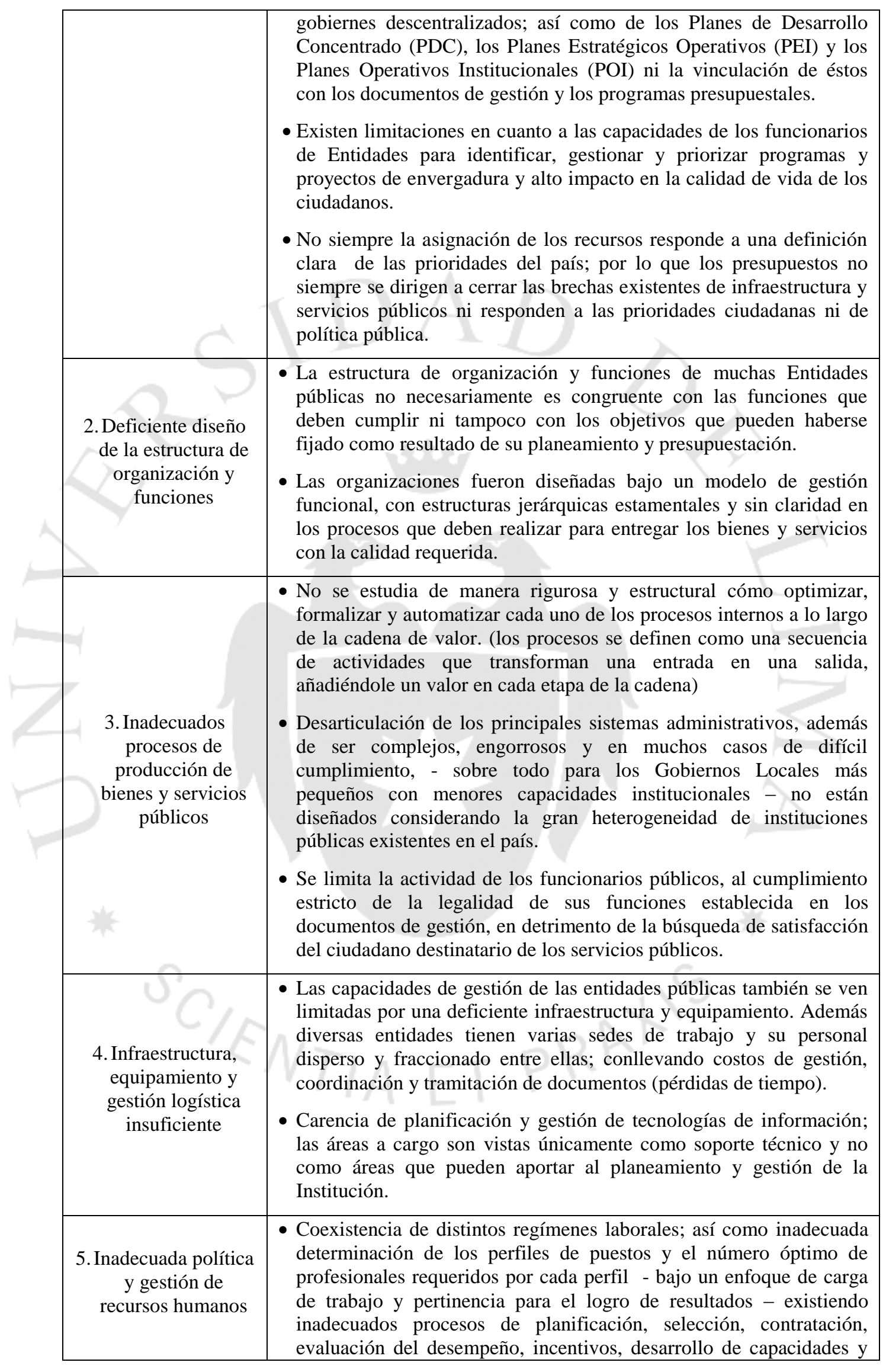




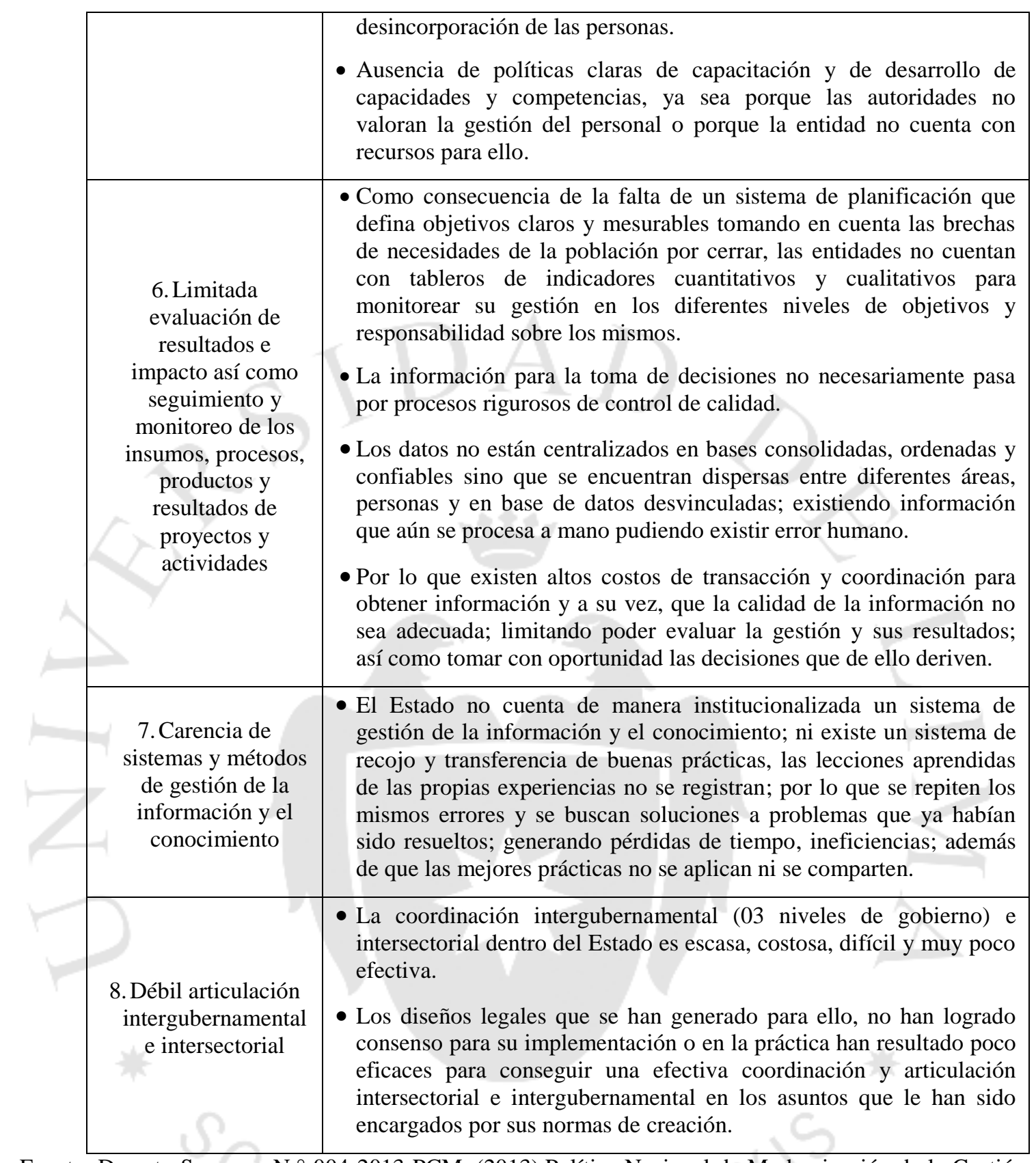

Fuente: Decreto Supremo N. ${ }^{\circ}$ 004-2013-PCM. (2013).Política Nacional de Modernización de la Gestión Pública.

En:http://sgp.pcm.gob.pe/wp-content/uploads/2015/06/DS-004-2013-PCM-Aprueba-la-PNMGP.pdf

Como advertimos, frente a estas deficiencias, el Estado peruano busca un proceso urgente de cambio y reforma integral de la gestión pública, pasando a ser una administración pública enfocada a la obtención de resultados para los ciudadanos. Dicho proceso, el Estado lo centra en componentes que serán los pilares de la Política de Modernización de la Gestión Pública, y que resultan importantes conocerlos y son: 


\subsubsection{Planeamiento de Estado: Políticas de Estado y de Gobierno:}

Las políticas públicas son diseños que sustentan la acción pública y son las que permiten integrar y dar coherencia a la intervención del Estado al servicio del ciudadano, a través de los objetivos establecidos en los Planes Gubernamentales, los Sectoriales, así como los Planes regionales y locales de desarrollo concertado y en los planes estratégicos y operativos de todas y cada una de las entidades del sector público en los tres niveles de gobierno. De este modo, el Estado busca actuar como un todo coherente y articulado con el propósito de servir mejor al ciudadano, brindándole un nivel de satisfacción mayor al que podría otorgarle una entidad que lo atendiera de manera individual y desarticulada (Decreto Supremo N. ${ }^{\circ}$ 004-2013-PCM, 2013).

Es por ello, que hasta la fecha se resalta la necesidad de contar con políticas de Estado claras y públicas; que puedan definir cuáles son las prioridades de gobierno - en un Estado peruano lleno de necesidades - para que sobre ello los proyectos de promoción de la inversión privada mediante APP pueda contribuir con el Estado en atender las demandas y necesidades esenciales de la población; caso contrario, no se advierte si la necesidad de incorporar experiencia, conocimientos, equipos especializados, y tecnología del sector privado está logrando resultados que impacten positivamente en el bienestar del ciudadano .

\subsubsection{Planeamiento Estratégico:}

Parte por considerar las prioridades del país y de sus ámbitos de gobierno (central, regional y local). El Plan Estratégico para la Política Nacional de Modernización de la Gestión Pública debe contener tanto los objetivos gubernamentales como los objetivos generales de la entidad, que se expresa como los resultados que ésta espera alcanzar con relación a la demanda ciudadana; por lo que los objetivos generales del Plan Estratégico deben reflejarse en los Planes Operativos, que contienen objetivos más específicos y metas claras de cantidad y calidad de producción de bienes y servicios que permitirán articular el presupuesto o programas presupuestales y así satisfacer las demandas ciudadanas, de manera eficaz y eficiente (Decreto Supremo N. ${ }^{\circ}$ 004-2013-PCM, 2013). 
Al respecto, el Centro Nacional de Planeamiento Estratégico (Ceplan, 2015) precisa que es el órgano técnico especializado rector del Sistema Nacional del Planeamiento Estratégico en el país - Sinaplan, el cual define al planeamiento estratégico como "el proceso sistemático construido sobre el análisis continuo de la situación actual y del pensamiento orientado al futuro, el cual genera información para la toma de decisiones con el fin de lograr los objetivos estratégicos establecidos"(p. 23).

Lamentablemente, hoy por hoy al planeamiento estratégico el Estado peruano le resta importancia, cada sector puede manejar el propio pero éstos no son construidos sobre la base de uno integrado como país; con lo cual se desconoce cuál es el propósito a ser alcanzado, no se tiene un norte claro y que a su vez, perdure en el tiempo como política de Estado y no de gobierno. Dicha situación conlleva que la ciudadanía no pueda sentir o advertir el beneficio que se está generando con la implementación de una política y cómo vamos avanzando en el cumplimiento de nuestros objetivos como país.

En la práctica, no se logra utilizar el planeamiento como una herramienta efectiva de gestión y no se articula el planeamiento con el presupuesto; es decir, sin un norte claro el Estado peruano no puede saber si lo que viene implementando o disponiendo como política de Estado - a través de la promoción de la inversión privada mediante APP - está contribuyendo a reducir las brechas sociales y económicas; así como de infraestructura que exige el país.

\subsubsection{Presupuesto para resultados:}

Un Estado Moderno al servicio del ciudadano, además de objetivos claros, requiere que sus presupuestos sean también asignados con orientación a resultados, es decir en función a los productos que los ciudadanos esperan recibir para satisfacer sus demandas; más si consideramos que los recursos del Estado son escasos, lo cual le obliga a priorizar. Ello contribuirá a dar un gran cambio en la gestión pública, de una gestión que se mira a sí misma, supeditada al proceso presupuestario, inercial a una gestión para la obtención de resultados para el ciudadano. Ello facilitará el cierre de brechas de calidad y cobertura de infraestructura y servicios públicos, con mayor eficiencia, economía, manteniendo el equilibrio fiscal y fortaleciendo la articulación de 
todas las entidades en el territorio nacional (Decreto Supremo N. ${ }^{\circ}$ 004-2013-PCM, 2013).

Es así que la reforma de la Nueva Gestión Pública nace durante la década de 1970 inspirada en la gerencia del sector privado que apuntó a modificar el modelo burocrático del Estado; en otras palabras se promueve ir de la administración pública a una gerencia pública conllevando la Gestión para Resultados en el Desarrollo; por lo que se busca transformar la cultura institucional imperante, basada en el cumplimiento de los procedimientos y crear una nueva orientada hacia resultados. Por ello, urge crear un ambiente político e institucional en el que los resultados sean el centro del debate público; en el que se juzgue a las autoridades por los cambios que han promovido en la sociedad; en el que los servidores públicos tengan incentivos para cumplir de manera eficiente su trabajo. Por ello su implementación en los países de América Latina y el Caribe debe darse no sólo como el reto de un gobierno en particular sino como un compromiso del Estado. (García y García, 2010, pp. 3-8)

Nuestro país no ha sido ajeno a este tipo de corrientes de reforma, habiéndose generado cambios principalmente en el Sistema Nacional de Presupuesto, buscando orientarlo a partir de los resultados que los ciudadanos requieren y valoran para el desarrollo. Es así que en la Ley de Presupuesto del sector público para el año 2007, comienza ya la idea del Presupuesto por Resultados (PpR).

El PpR , tuvo el liderazgo técnico y funcional del Ministerio de Economía y Finanzas - MEF. Esta reforma se motivó por la necesidad de inducir cambios en el ciclo presupuestal que permitan alinear la acción del Estado - financiado a través del presupuesto público - hacia el logro de resultados en bienestar del ciudadano. Se establece el PpR como una estrategia de gestión pública, con el objetivo de contribuir a una mayor eficiencia y eficacia del gasto público, a través de una completa vinculación entre los recursos públicos asignados y los productos y resultados propuestos para favorecer a la población; por lo que se trata de asegurar que cuando se formule el presupuesto se tome en cuenta los resultados a ser alcanzados por el país. Por ello, debe ser entendido el PpR como un contrato, un compromiso, en el que las entidades reciben una transferencia de recursos por la entrega adecuada (eficiente y eficaz) de bienes y 
servicios que redundan en un mayor bienestar social.(Acuña, Huiata y Mesinas, 2012, pp. 1-7)

Por ello, advertimos, que este planteamiento de la reforma PpR exige cambios drásticos a la administración pública, la cual no estuvo acostumbrada a estructurarse y a operar en función a resultados que impacten positivamente en beneficio del ciudadano. Este cambio plantea un desafío significativo para ella, induciéndola a repensar sus objetivos, estrategias, intervenciones, sistemas administrativos, y alianzas estratégicas con el sector privado en términos del ciudadano.

Es así que, teniendo en cuenta la herramienta de $\mathrm{PpR}$ nacen los programas presupuestales, al respecto Acuña, R., Huaita, F. y Mesinas, J. (2012), precisan

En su documento en camino de un Presupuesto por Resultados (PpR): Una nota sobre los avances recientes en la programación presupuestaria, se define: Programas Presupuestales: como las unidades de programación de las acciones del Estado que se realizan en cumplimiento de las funciones encomendadas a favor de la sociedad. Su existencia se justifica por la necesidad de lograr un resultado para la población objetivo, en concordancia con los objetivos estratégicos de la política de Estado formulados por el Centro Nacional de Planeamiento Estratégico (CEPLAN), órgano rector del Sistema Nacional de Planeamiento Estratégico, pudiendo a involucrar a Entidades de diferentes sectores y niveles de gobierno. Cuentan con un responsable y un responsable técnico. Ellos asumen el diseño y la implementación del programa. Deben entregar información sobre la descripción y metas de entrega de productos, indicadores de resultados, uso de las evidencias en sus diseños causales, entre otras, que sean requeridas (p.5)

Los cuales se enmarcan en una gestión por resultados, la cual utiliza una cadena de valor, en donde se ha definido lo siguiente: a) Insumo: Bienes y servicios necesarios y suficientes para llevar adelante la actividad; b) Actividad: Acción sobre una lista específica y completa de insumos, que en conjunto con otras actividades garantizan la provisión del producto; c) Producto: Conjunto articulado de bienes y/o servicios que recibe la población beneficiaria con el objeto de generar un cambio; d) $\underline{\text { Resultado }}$ Específico (Resultado):Es el cambio que se busca alcanzar para solucionar un problema identificado sobre una población objetivo, y que a su vez, contribuye al logro de un resultado final; este resultado no constituye un fin en sí mismo; y e) Resultado final (Impacto): Es un cambio en las condiciones, cualidades o características inherentes a 
una población identificada, corresponde a un objetivo de política nacional (Decreto Supremo N. ${ }^{\circ}$ 004-2013-PCM, 2013).

Es en ese contexto, que también debemos tener en cuenta la cadena de valor en los proyectos de inversión mediante APP durante el proceso de producción de infraestructura y servicios públicos, de acuerdo a lo siguiente:

Figura 1.1.

Cadena de valor durante el proceso de producción de infraestructura y servicios públicos a través de APP.

\section{Políticas de Estado y de Gobierno}

Proceso de producción de infraestructura y servicios públicos a través de APP

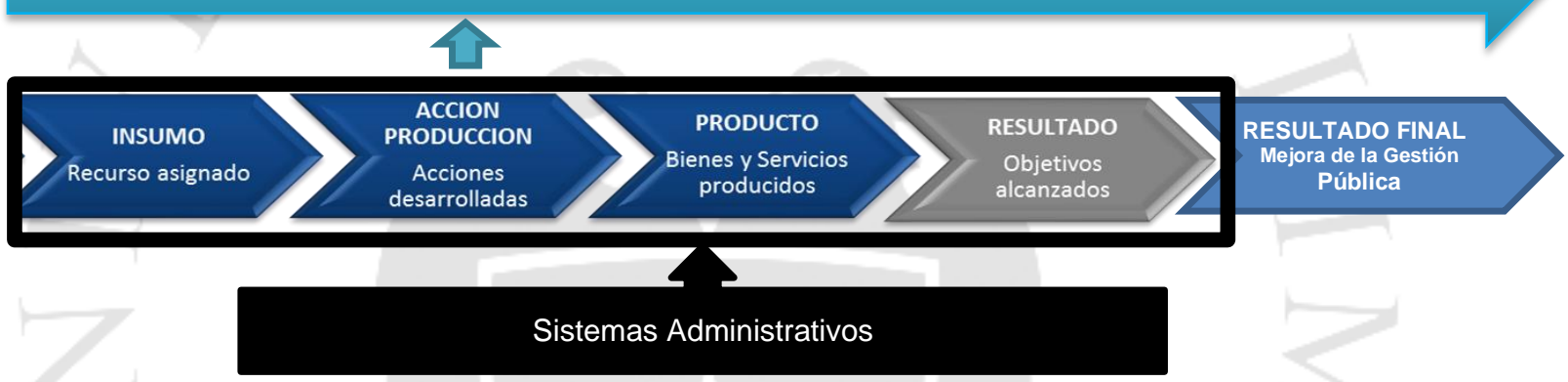

Fuente: Decreto Supremo N. ${ }^{\circ}$ 004-2013-PCM (2013) adaptado de la Política Nacional de Modernización de la Gestión Pública.

Como observamos, se advierte la necesidad de contar con objetivos definidos, un norte claro como parte del planeamiento estratégico, el cual debe estar diseñado como parte de la Política de Estado y de gobierno; a efecto de que podamos medir si el resultado que vienen dando los proyectos de inversión en el marco de APP están logrando resultados que impacten en el bienestar del ciudadano; y con ello en la mejora de la gestión pública.

\subsubsection{Gestión por resultados:}

Una gestión al servicio del ciudadano debe cambiar el tradicional modelo de organización funcional y migrar hacia una organización por procesos, contenidos en la “cadena de valor" de cada entidad, que aseguren que los bienes y servicios públicos de su responsabilidad generan resultados e impactos positivos para el ciudadano, siendo 
que los procesos son definidos como una secuencia de actividades que transforman una entrada o insumo (una solicitud de un bien o servicio) en una salida (la entrega del bien o servicio) añadiéndole "un valor" en cada etapa de la cadena. Existen procesos "clave" de la cadena de valor; y otros de "soporte" que sirven de manera transversal a todas las actividades; estableciéndose que en el modelo de gestión por resultados, los dos tipos de procesos deben ser optimizados. (Decreto Supremo N. ${ }^{\circ}$ 004-2013-PCM, 2013).

Lo que busca una cadena de valor es procurar generar el mayor valor posible en cada una de las actividades desagregadas, y al mismo tiempo procurar minimizar los costos sin lesionar calidad en cada una de éstas; con lo cual se logra obtener el mayor margen de utilidad posible (value for money). De lo que se trata es de generar valor público, diferente de lo que se busca en el sector privado, cuyo valor es generar mayores utilidades (valor privado).

\subsubsection{Servicio civil meritocrático:}

Se precisa que la gestión de recursos humanos es siempre crítica en toda organización, plantea que deben ser 03 los atributos fundamentales los del servidor público: a) la responsabilidad ante las autoridades democráticamente elegidas; b) La independencia política que deben tener dado que deben defender los intereses de los ciudadanos y garantizar la neutralidad de la acción pública; y c) capacidad técnica para desarrollar políticas públicas eficaces. Asimismo, orienta a reflexionar que una mayor rigidez no eleva el cumplimiento ni reduce la corrupción pero sí puede llevar a una ineficiencia y parálisis; habiéndose evidenciado la necesidad de flexibilizar para dar espacio a los gestores para dirigir las organizaciones, adaptarse a los cambios y emprender prácticas innovadoras en beneficio del ciudadano.(Decreto Supremo N. ${ }^{\circ}$ 004-2013-PCM, 2013).

\subsubsection{Seguimiento, evaluación y gestión del conocimiento:}

Un elemento imprescindible de la gestión por resultados es el proceso continuo de recolección y análisis de datos que conlleva como objetivo el seguimiento y monitoreo de los indicadores de insumo, proceso y producto; así como la evaluación de los resultados e impacto de las actividades, programas y proyectos desarrollados por la 
entidad, con el propósito de mejorar o garantizar la provisión de productos o servicios a los ciudadanos. A través de esta forma, se busca medir el desempeño de la institución por medio del grado de cumplimiento de sus metas de asignación de recursos en función de sus prioridades establecidas; es decir se busca medir con transparencia, la eficacia en el cumplimiento de los objetivos, la eficiencia en el uso de los recursos y la calidad o el grado de satisfacción percibida por los ciudadanos atendidos. Esta información debe generar el conocimiento adecuado para la mejora continua de la calidad de la acción del Estado en el servicio al ciudadano. (Decreto Supremo N. ${ }^{\circ}$ 0042013-PCM, 2013).

Como evidenciamos, el desarrollo de un proyecto implica todo un proceso productivo que nace desde una necesidad priorizada que atender diseñada en una política pública (escasos recursos y múltiples requerimientos) para lo cual teniendo clara la planificación y su resultado se asigna el presupuesto y los insumos; ello para que permita se realice actividades ya definidas, lo cual dará lugar a bienes o servicios (producto). Estos productos al ser recibidos por la población beneficiaria generan un resultado a mediano y largo plazo; sin embargo, el Estado espera que sean la solución al problema o que generen la eliminación de la necesidad que le dio origen. Para el logro de dicho resultado resulta vital el seguimiento y evaluación que me permitirá contar con alertas tempranas durante todo el ciclo del servicio o bien a fin de tomar decisiones o medidas correctivas informadas; y a su vez, los indicadores permitirán evaluar si se viene cumpliendo con lo planificado, en aras de lograr el impacto positivo en el bienestar del ciudadano.

La gestión del conocimiento, por otro lado busca administrar conocimiento y los aprendizajes organizacionales para mejorar el funcionamiento de las entidades, tomando en cuenta las buenas prácticas propias y de terceros para retroalimentar el diseño e implementación de sus estrategias de acción y así poder asegurar el resultado esperado (Decreto Supremo N. ${ }^{\circ}$ 004-2013-PCM, 2013).

\subsection{Marco normativo de las APP y principales cambios}


En el Perú, luego de pasar por un escenario donde el Estado controlaba toda clase de servicios públicos, los cuales en un momento colapsaron y no llegaron a satisfacer de forma eficiente al ciudadano, es que se opta por promocionar la participación de las empresas privadas en actividades que antes eran exclusivas del Estado. Es así que, en la década de los noventa se establecen los primeros impulsos normativos de la inversión privada, primero con las privatizaciones, luego las concesiones, y por último se fomenta la figura contractual de las asociaciones público privadas. Así tenemos:

Figura 1.2.

Marco legal para la promoción de la inversión Privada en el Perú

1991

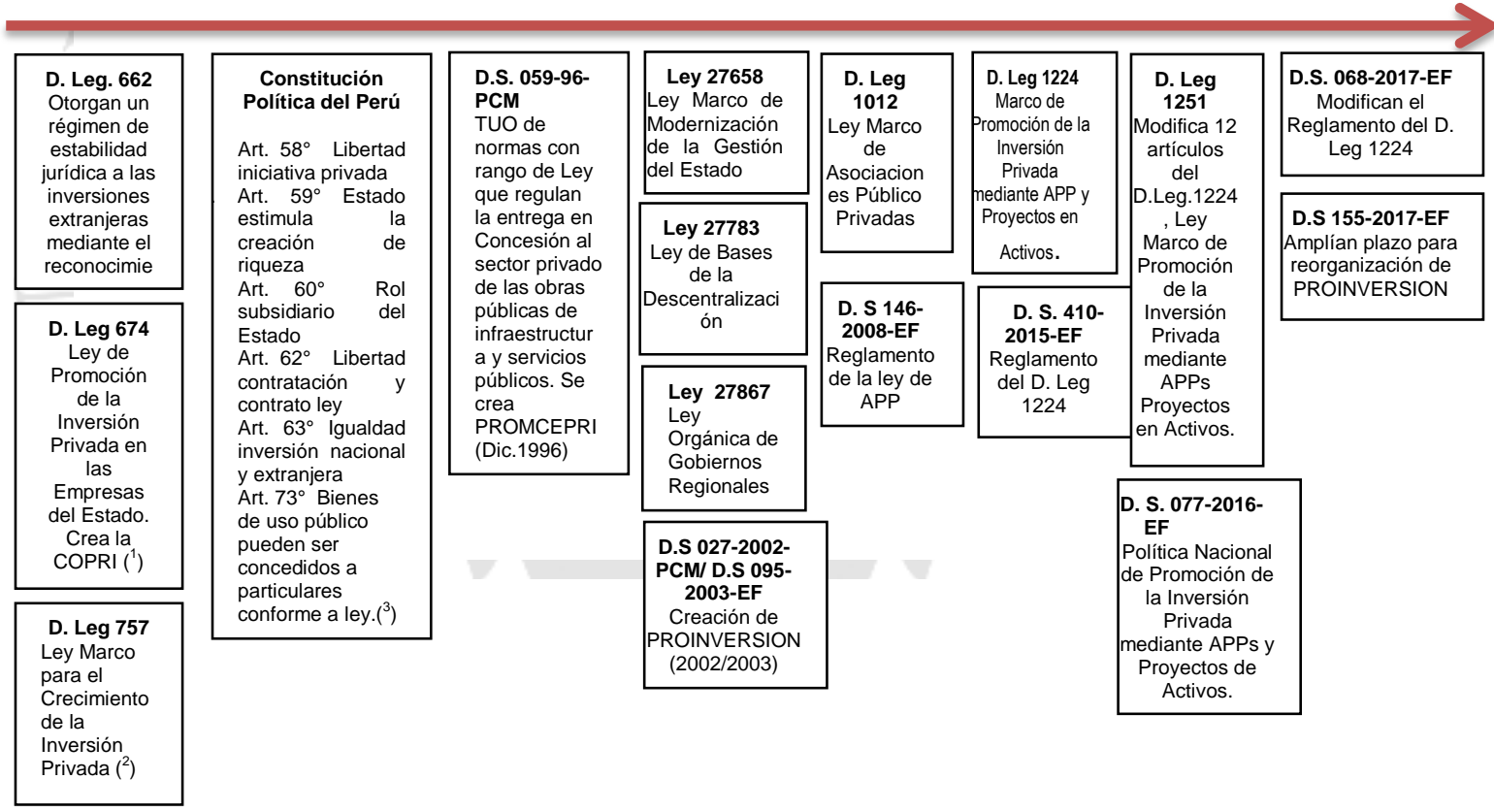

Nota:

(1) Primer Párrafo del Artículo $1^{\circ}$ "Declárase de interés nacional la promoción de la inversión privada en el ámbito de las empresas que conforman la Actividad Empresarial del Estado”.

(2) Segundo Párrafo del Artículo $1^{\circ}$ "Establece derechos, garantías y obligaciones que son de aplicación a todas las personas naturales o jurídicas, nacionales o extranjeras, que sean titulares de inversiones 
en el país. Sus normas son de observancia obligatoria por todos los organismos del Estado, ya sean del Gobierno Central, Gobiernos Regionales, o Locales, a todo nivel."

(3) Art. $58^{\circ}$ "La iniciativa privada es libre. Se ejerce en una economía social de mercado. Bajo este régimen, el Estado orienta el desarrollo del país, y actúa principalmente en las áreas de promoción de empleo, salud, educación, seguridad, servicios públicos e infraestructura."

Fuente: Normas Legales - Diario Oficial El Peruano.

Conforme observamos en la figura 1.2 es a partir del año 2008, que se inicia propiamente la regulación normativa de las Asociaciones Público Privadas - APP, dando apertura a una novedosa forma contractual con la participación de la inversión privada, en la que se incorpora experiencia, conocimientos, equipos, tecnología y se distribuyen riesgos y recursos, preferentemente privados, con el objeto de crear, desarrollar, mejorar, operar o mantener infraestructura pública y/o proveer servicios públicos. (Decreto Legislativo N.` 1224, 2015)

Resulta importante para este trabajo de investigación, mirar con detalle la normativa generada de APP desde el periodo 2008, incidiendo en la regulación que se ha venido dando y en las modificaciones contractuales durante la etapa de ejecución contractual, conforme se precisa a continuación:

Tabla 1.2.

Detalle de la normativa de APP y precisiones en torno a modificaciones contractuales

\begin{tabular}{|c|c|c|c|}
\hline Año & Normatividad & Publicación & Que se dispone \\
\hline 2008 & $\begin{array}{l}\text { Decreto Legislativo } \mathbf{N}^{\circ} \\
1012 \quad \text { Marco de } \\
\text { Ley Público } \\
\text { Asociaciones (APP) } \\
\text { Privadas } \\
\text { (Derogada por el D.L. } \\
\text { 1224) }\end{array}$ & $13 / 05 / 2008$ & $\begin{array}{l}\text { "Artículo 3.- Definición de Asociación } \\
\text { Público- Privada (APP) } \\
\text { Asociaciones Público - Privadas-APP } \\
\text { son modalidades de participación de la } \\
\text { inversión privada en las que se incorpora } \\
\text { experiencia, conocimientos, equipos, } \\
\text { tecnología, y se distribuyen riesgos y } \\
\text { recursos, preferentemente privados, con } \\
\text { el objeto de crear, desarrollar, mejorar, } \\
\text { operar o mantener infraestructura } \\
\text { pública, proveer servicios públicos y/o } \\
\text { prestar los servicios vinculados a éstos } \\
\text { que requiera brindar el Estado, así como }\end{array}$ \\
\hline
\end{tabular}




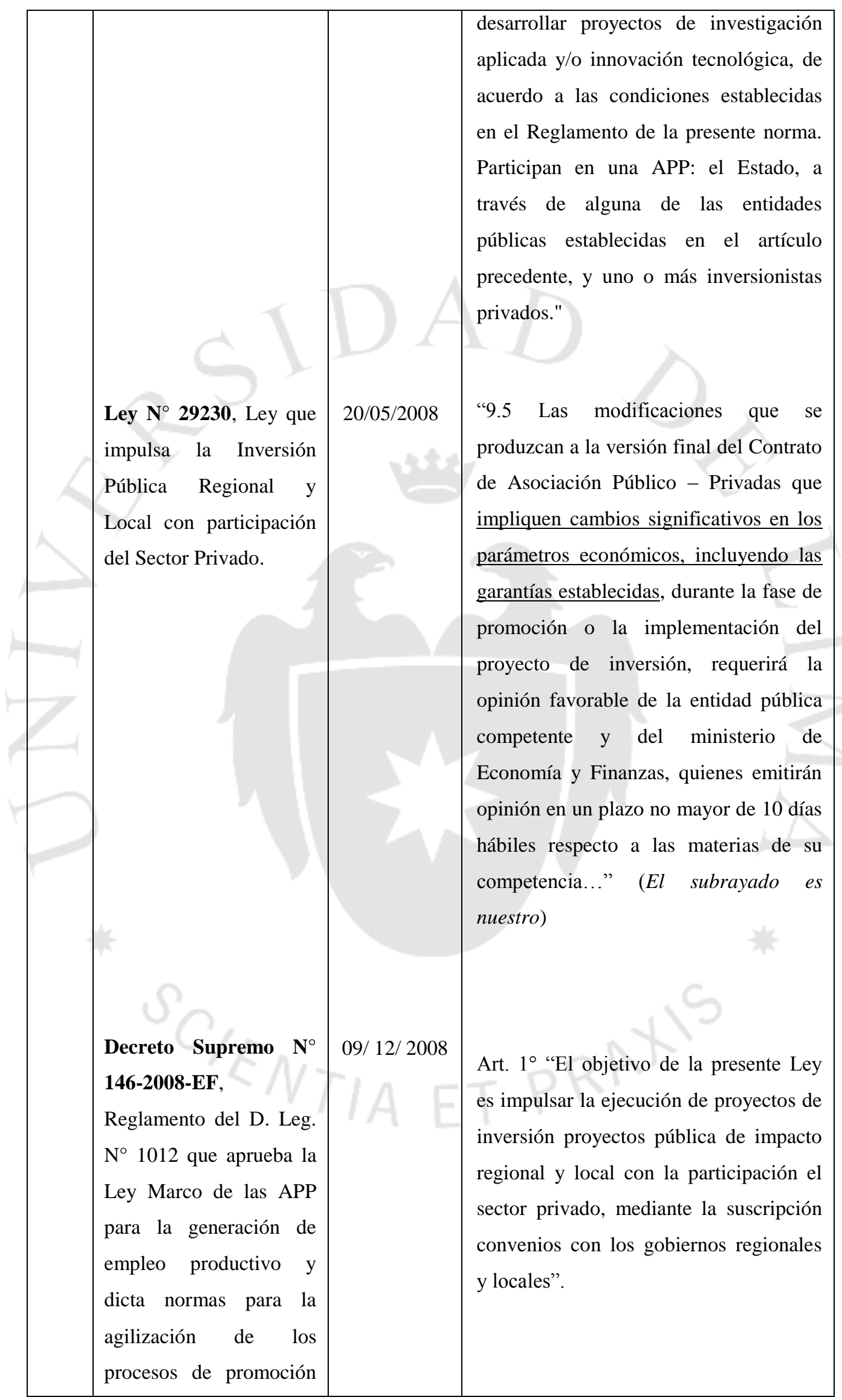




\begin{tabular}{|c|c|c|c|}
\hline & $\begin{array}{l}\text { de la inversión privada. } \\
\text { (Derogado) }\end{array}$ & & $\begin{array}{l}\text { Título III Régimen de Iniciativas } \\
\text { Privadas.- Art. } 13^{\circ} \text { Objeto.- ..."regular } \\
\text { el tratamiento de los proyectos de } \\
\text { inversión en activos, empresas, } \\
\text { proyectos, servicios que se ejecuten } \\
\text { como consecuencia de la iniciativa } \\
\text { privada, en el ámbito de las respectivas } \\
\text { competencias de los distintos niveles de } \\
\text { gobierno. }\end{array}$ \\
\hline 2013 & $\begin{array}{l}\text { Ley del Presupuesto } \\
\text { para el Sector Público } \\
\text { para el año Fiscal } 2014\end{array}$ & $02 / 12 / 2013$ & $\begin{array}{lc}\text { Artículo } 17^{\circ} & \text { Fondo de Apoyo a las } \\
\text { Asociaciones } & \text { Público } \\
\text { Cofinanciadas } & \text { (Fondo APP) }\end{array}$ \\
\hline 2014 & $\begin{array}{l}\text { Ley } \mathbf{N}^{\circ} \text { 30167, Modifica } \\
\text { el Decreto Legislativo } \\
\mathrm{N}^{\circ} \\
\text { 1012, que aprueba la } \\
\text { Ley Marco de APP para } \\
\text { la generación de empleo } \\
\text { productivo y dicta } \\
\text { normas para la } \\
\text { agilización de los } \\
\text { procesos de la inversión } \\
\text { privada. (Derogado) }\end{array}$ & $02 / 03 / 2014$ & $\begin{array}{l}\text { Modifica los artículos } 1,2,3,4,7,8 \text { del } \\
\text { epígrafe y los numerales } 9.1,9.2,9.3 \text { y } \\
\text { el segundo párrafo del numeral 9.7 del } \\
\text { artículo 9, de los artículos } 14,15,16,17 \text {, } \\
\text { así como el epígrafe del artículo 16, del } \\
\text { Decreto Legislativo } N^{\circ} 1012 . \\
\text { "Artículo 3.- Definición de Asociación } \\
\text { Público-Privada (APP) } \\
\text { Asociaciones Público - Privadas-APP } \\
\text { son modalidades de participación de la } \\
\text { inversión privada en las que se incorpora } \\
\text { experiencia, conocimientos, equipos, } \\
\text { tecnología, y se distribuyen riesgos y } \\
\text { recursos, preferentemente privados, con } \\
\text { el objeto de crear, desarrollar, mejorar, } \\
\text { operar o mantener infraestructura } \\
\text { pública, proveer servicios públicos y/o } \\
\text { prestar los servicios vinculados a éstos } \\
\text { que requiera brindar el Estado, así como } \\
\text { desarrollar proyectos de investigación } \\
\text { aplicada y/o innovación tecnológica, de } \\
\text { acuerdo a las condiciones establecidas } \\
\text { en el Reglamento de la presente } \\
\text { norma...”. }\end{array}$ \\
\hline
\end{tabular}




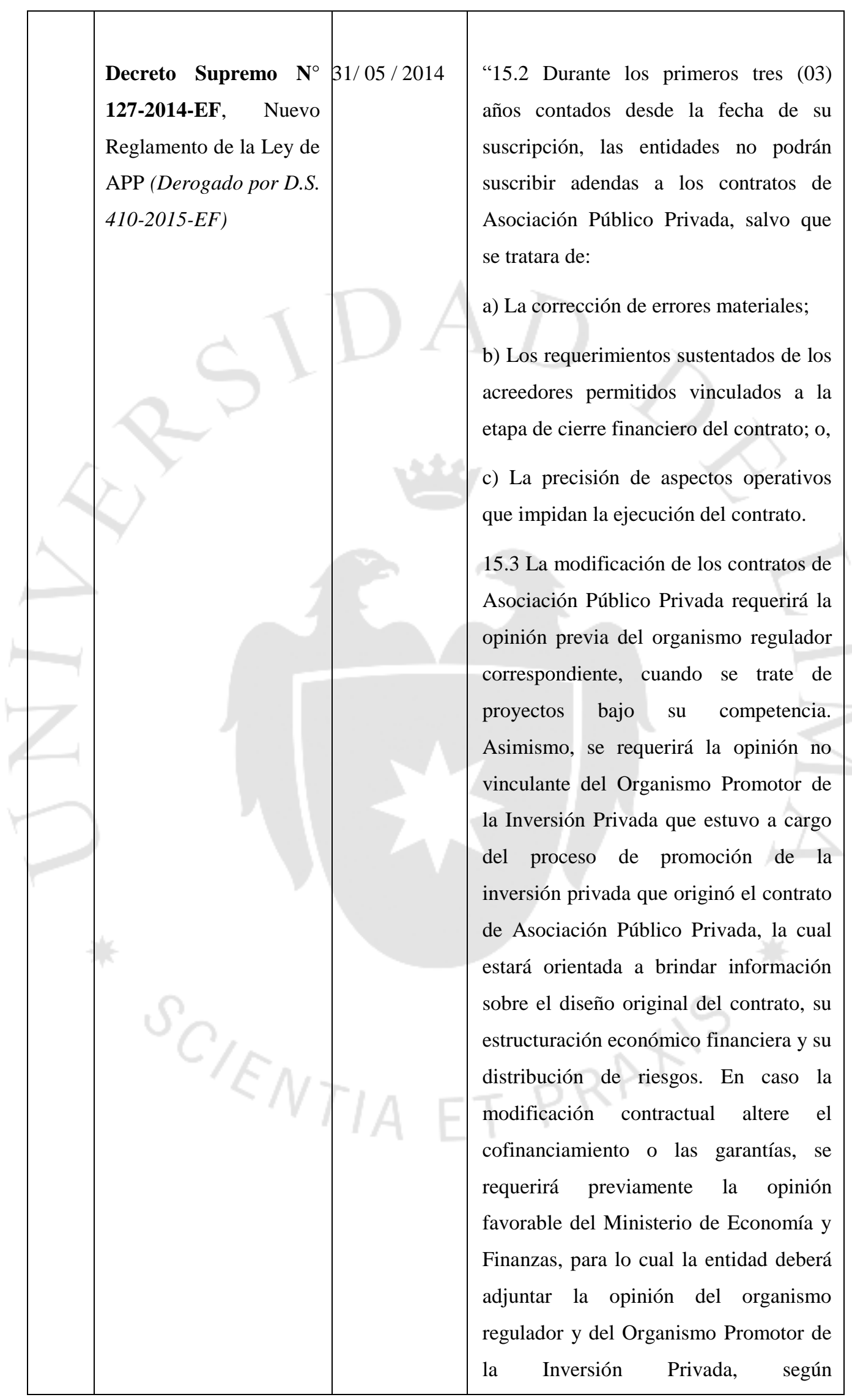




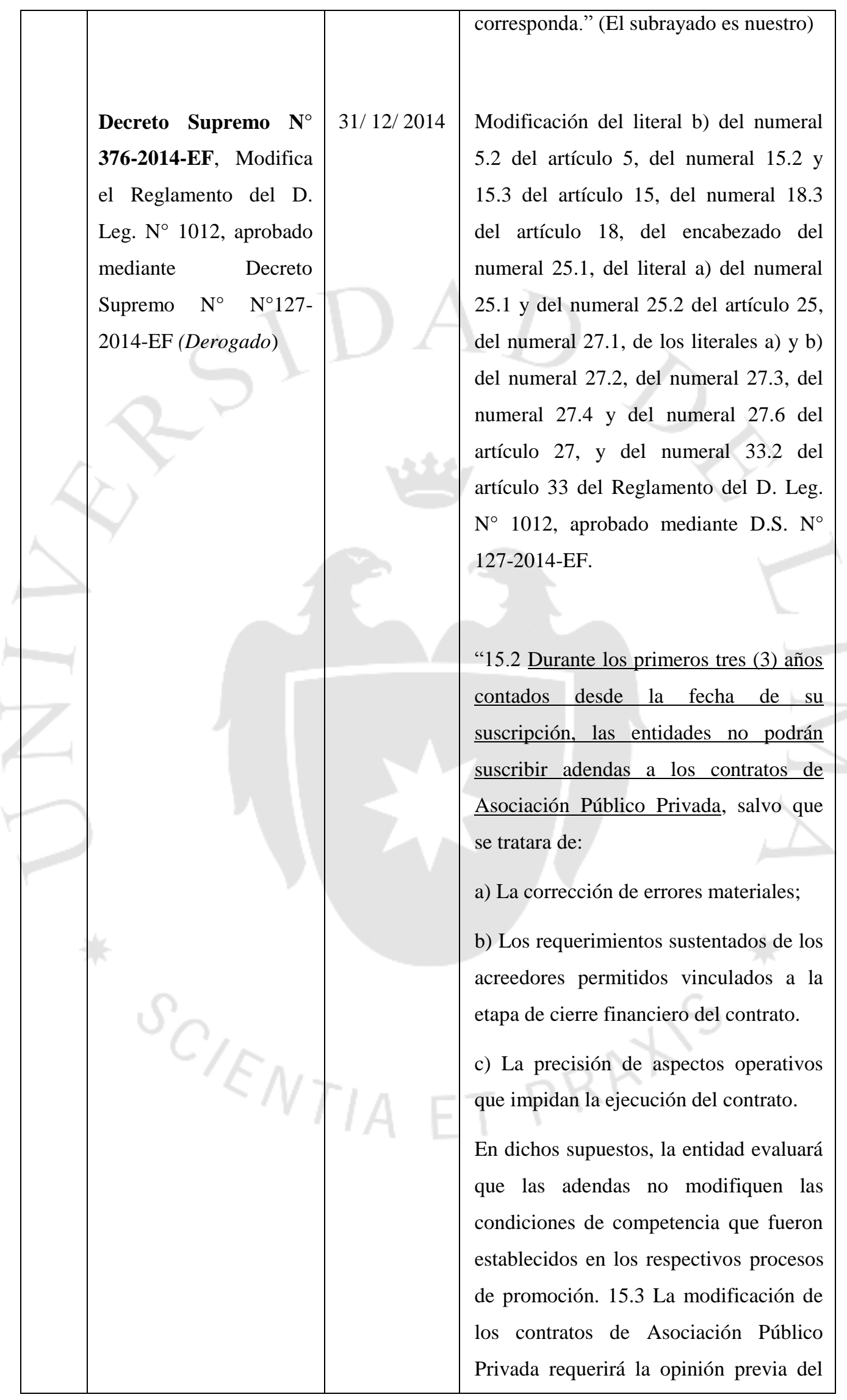




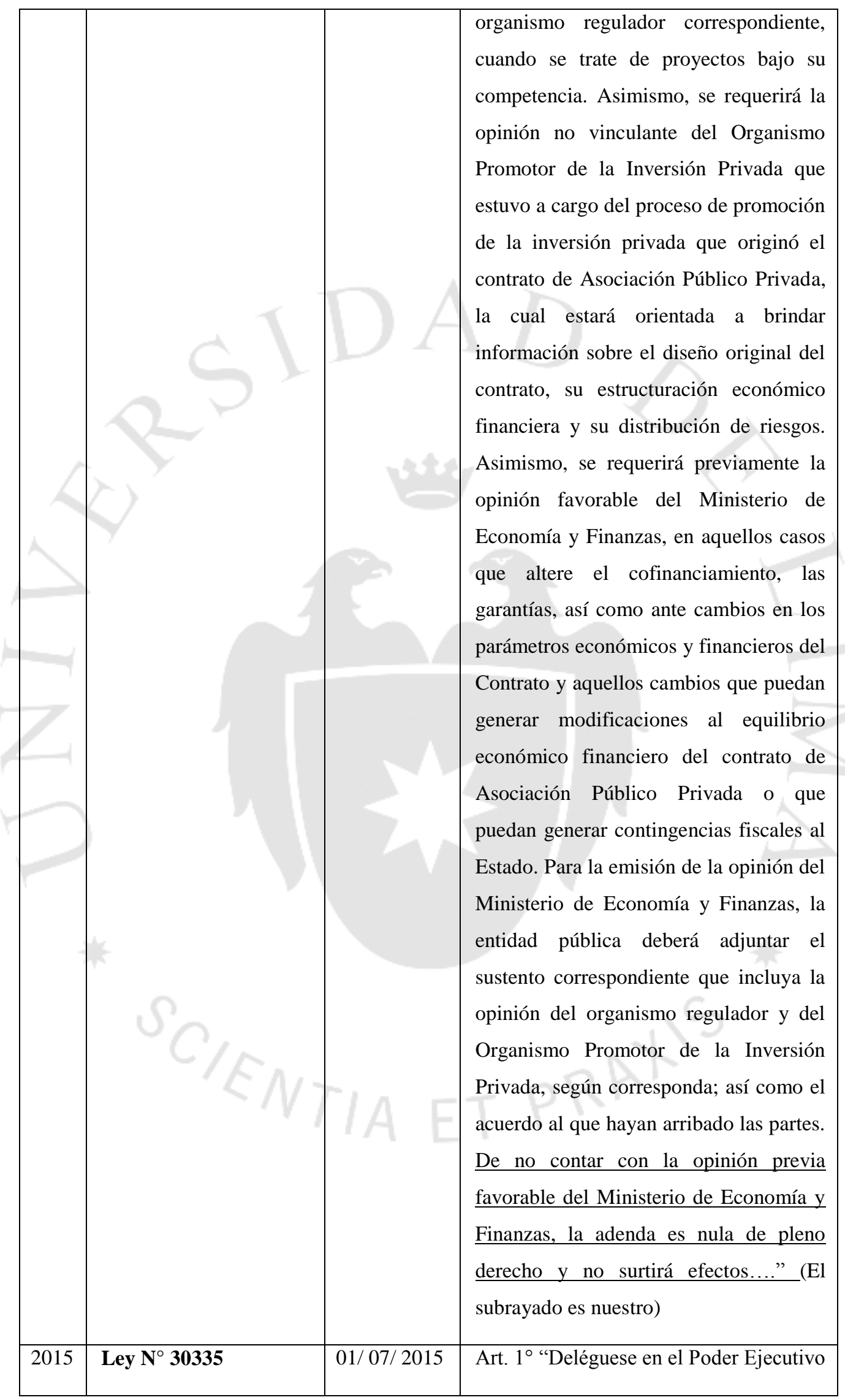




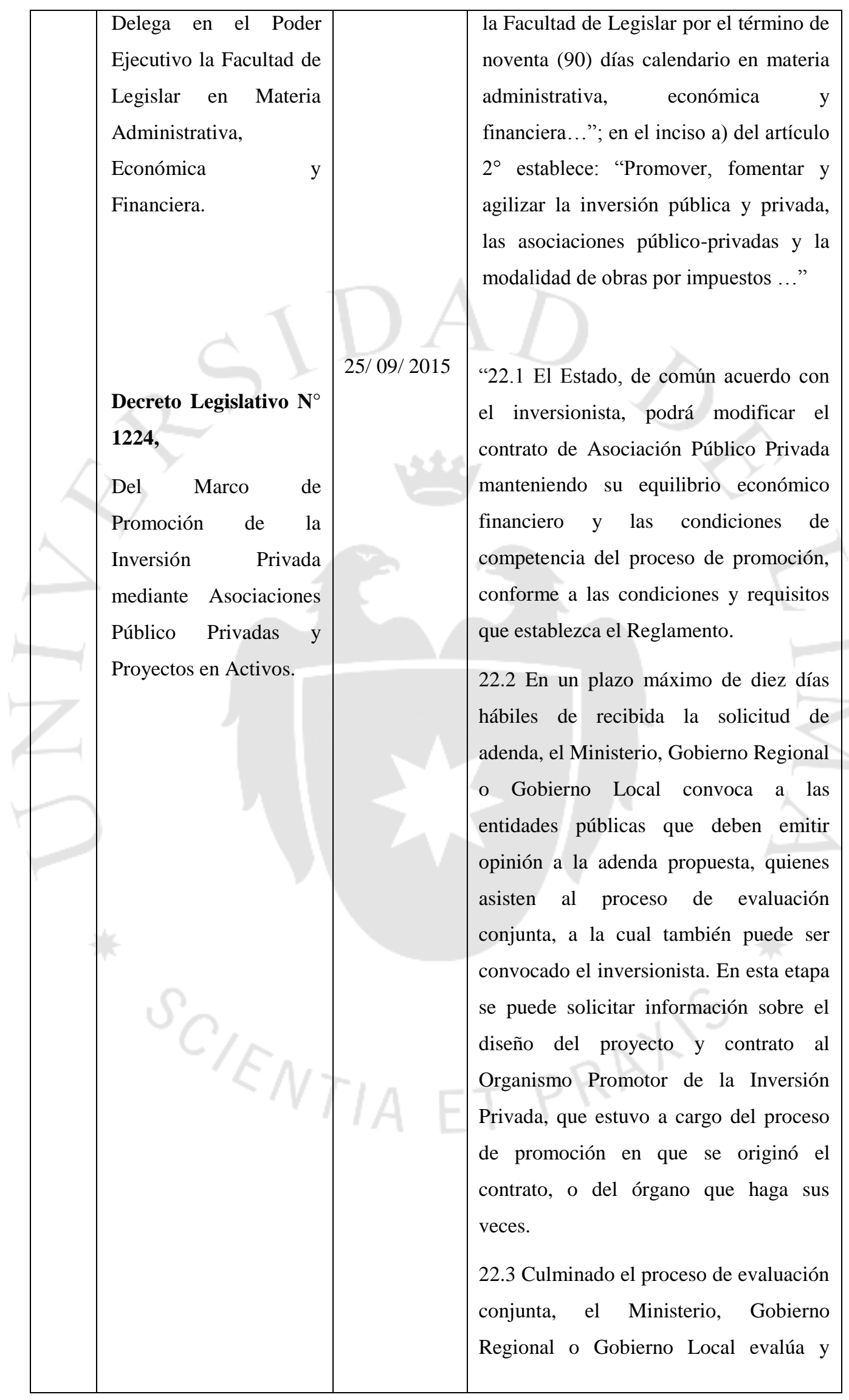




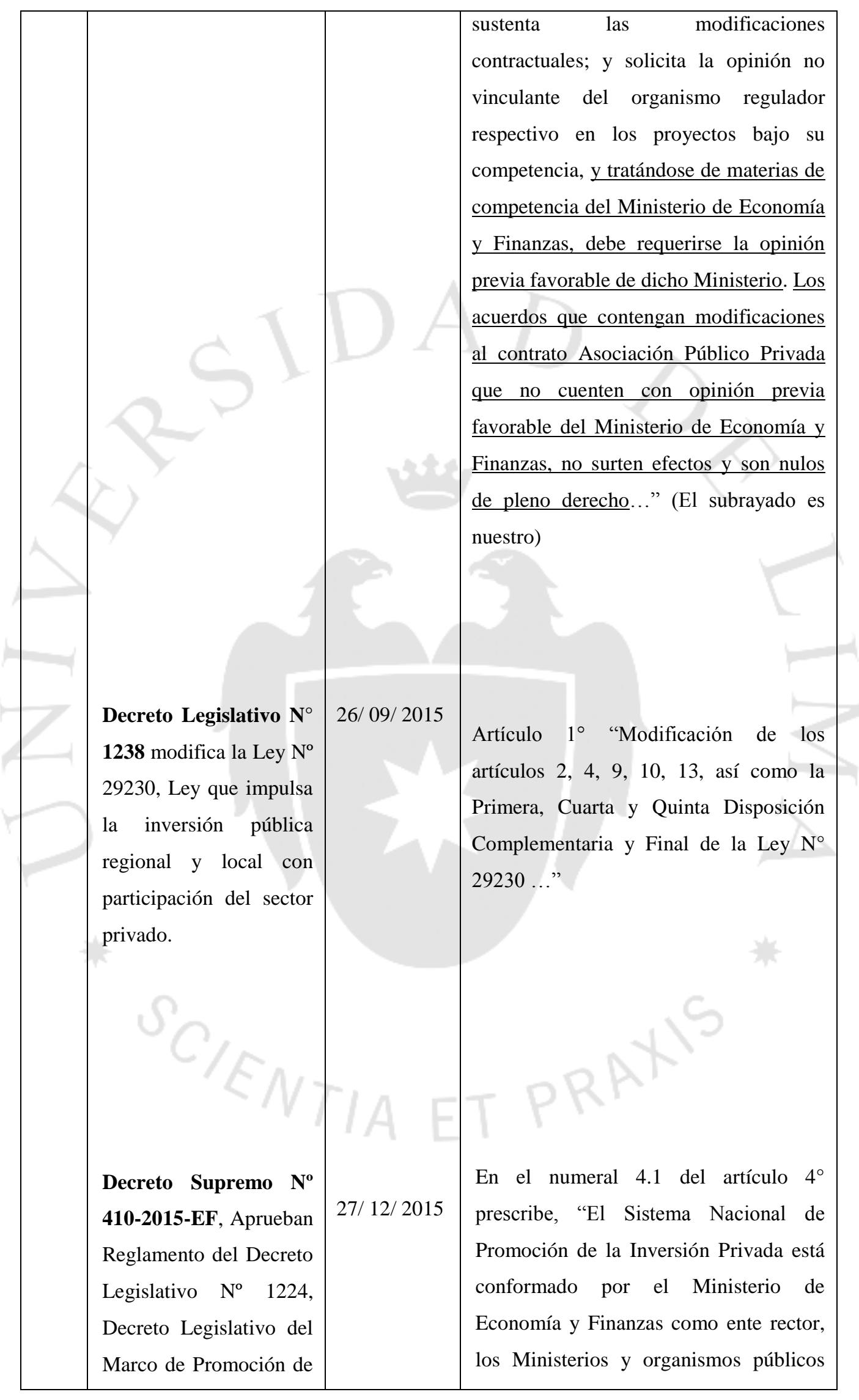




\begin{tabular}{|c|c|c|c|}
\hline & $\begin{array}{l}\text { la Inversión Privada } \\
\text { mediante Asociaciones } \\
\text { Público Privadas y } \\
\text { Proyectos en Activos. }\end{array}$ & & $\begin{array}{l}\text { del Gobierno Nacional, la Agencia de } \\
\text { Promoción de la Inversión Privada - } \\
\text { PROINVERSIÓN, los Gobiernos } \\
\text { Regionales y los Gobiernos Locales. Se } \\
\text { regula de manera unificada en lo técnico } \\
\text { normativo, correspondiendo a las } \\
\text { entidades públicas, la priorización y } \\
\text { desarrollo de los proyectos de } \\
\text { Asociación Público Privada y Proyectos } \\
\text { en Activos." } \\
\text { "Artículo } 53 .- \text { Modificaciones } \\
\text { contractuales Las partes pueden } \\
\text { convenir en modificar el contrato de } \\
\text { Asociación Público Privada, } \\
\text { manteniendo el equilibrio económico } \\
\text { financiero y las condiciones de } \\
\text { competencia del proceso de promoción, } \\
\text { procurando no alterar la asignación de } \\
\text { riesgos y la naturaleza del proyecto. } \\
\text { Artículo } 54 \text {.- Límite temporal para la } \\
\text { suscripción de adendas Durante los tres } \\
\text { (03) primeros años contados desde la } \\
\text { fecha de suscripción del contrato, no } \\
\text { pueden suscribirse adendas a los } \\
\text { contratos de Asociación Público } \\
\text { Privada, salvo que se trate de: } \\
\text { a. La corrección de errores materiales. } \\
\text { b. Los requerimientos sustentados de los } \\
\text { acreedores permitidos, vinculados a la } \\
\text { etapa de cierre financiero del contrato. } \\
\text { c. La precisión de aspectos operativos } \\
\text { que impidan la ejecución del contrato..". }\end{array}$ \\
\hline 2016 & $\begin{array}{l}\text { Decreto Supremo } \text { n. }^{\circ} \\
\text { 077-2016-EF. Política } \\
\text { Nacional de Promoción } \\
\text { de la Inversión Privada }\end{array}$ & $10 / 04 / 2016$ & $\begin{array}{l}\text { Busca constituirse como uno de los } \\
\text { principales instrumentos de política } \\
\text { pública que permita fomentar la } \\
\text { participación del sector privado en las }\end{array}$ \\
\hline
\end{tabular}




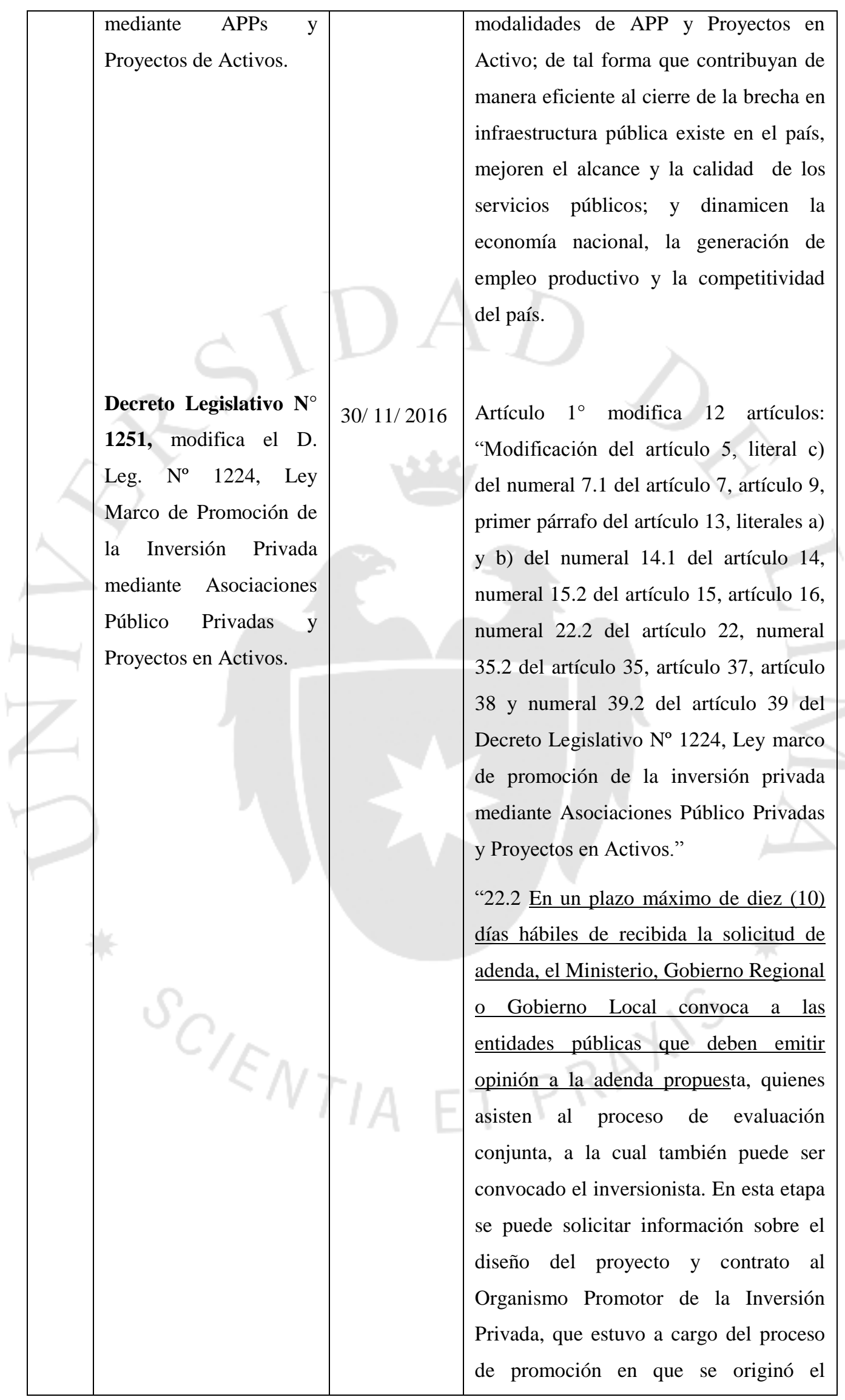




\begin{tabular}{|c|c|c|c|}
\hline & & & $\begin{array}{l}\text { contrato, o del órgano que haga sus } \\
\text { veces. En los contratos de Asociaciones } \\
\text { Público Privadas a cargo de Proinversión } \\
\text { las propuestas de modificación a dichos } \\
\text { contratos se presentan ante dicha entidad } \\
\text { dentro del periodo establecido en el } \\
\text { Reglamento, quien convoca y conduce el } \\
\text { proceso de evaluación conjunta, y emite } \\
\text { opinión de acuerdo a lo establecido en el } \\
\text { Reglamento. En los supuestos previstos } \\
\text { en el presente numeral, el inversionista } \\
\text { puede solicitar su participación en el } \\
\text { proceso de evaluación conjunta..”. (El } \\
\text { subrayado es nuestro) }\end{array}$ \\
\hline 2017 & 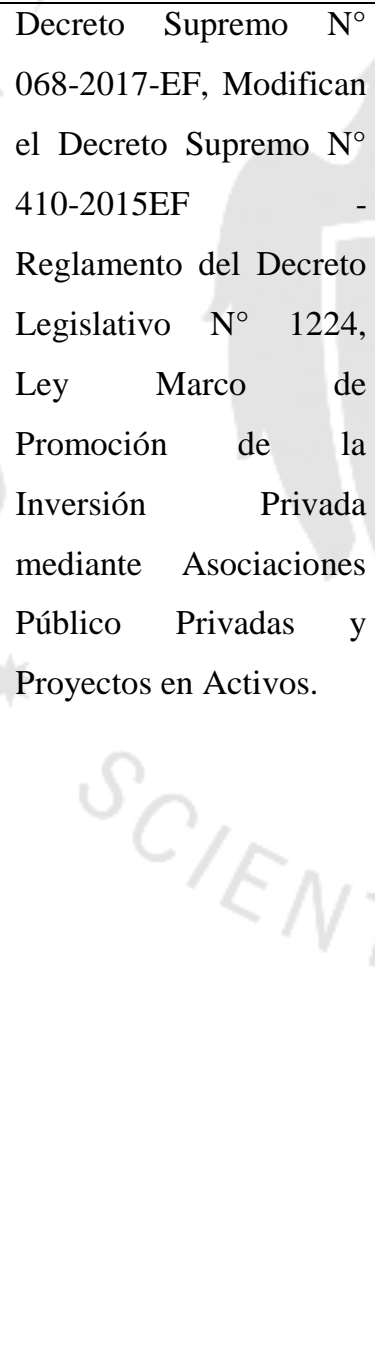 & $28 / 03 / 2017$ & 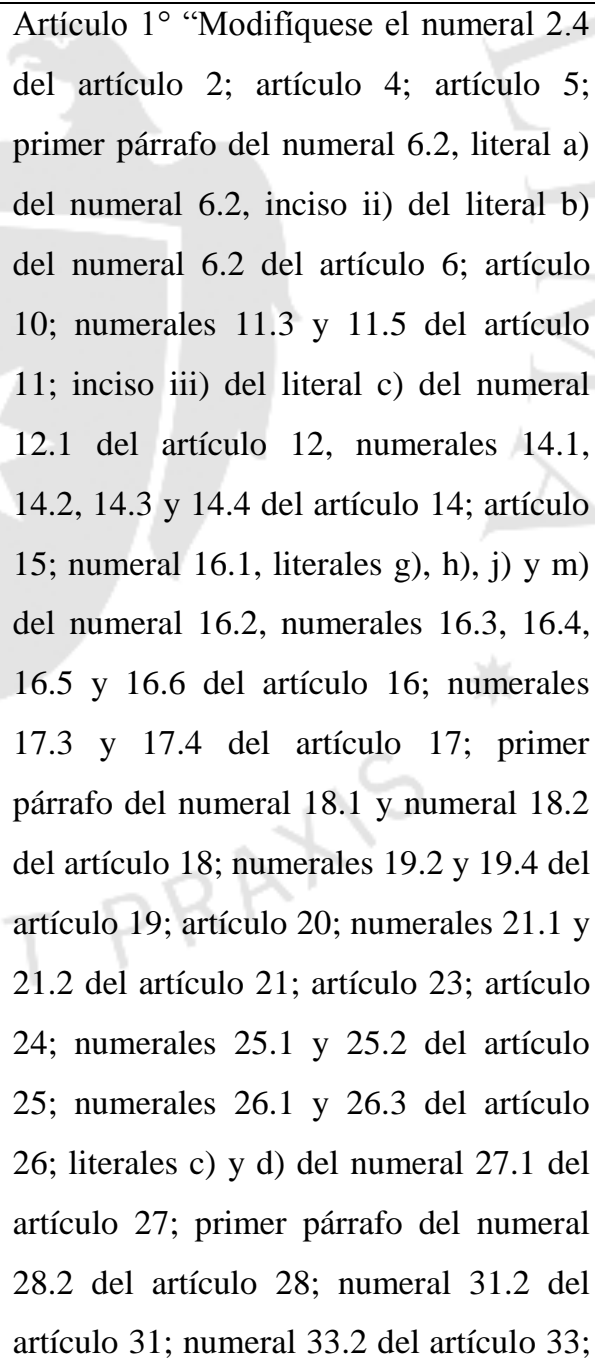 \\
\hline
\end{tabular}




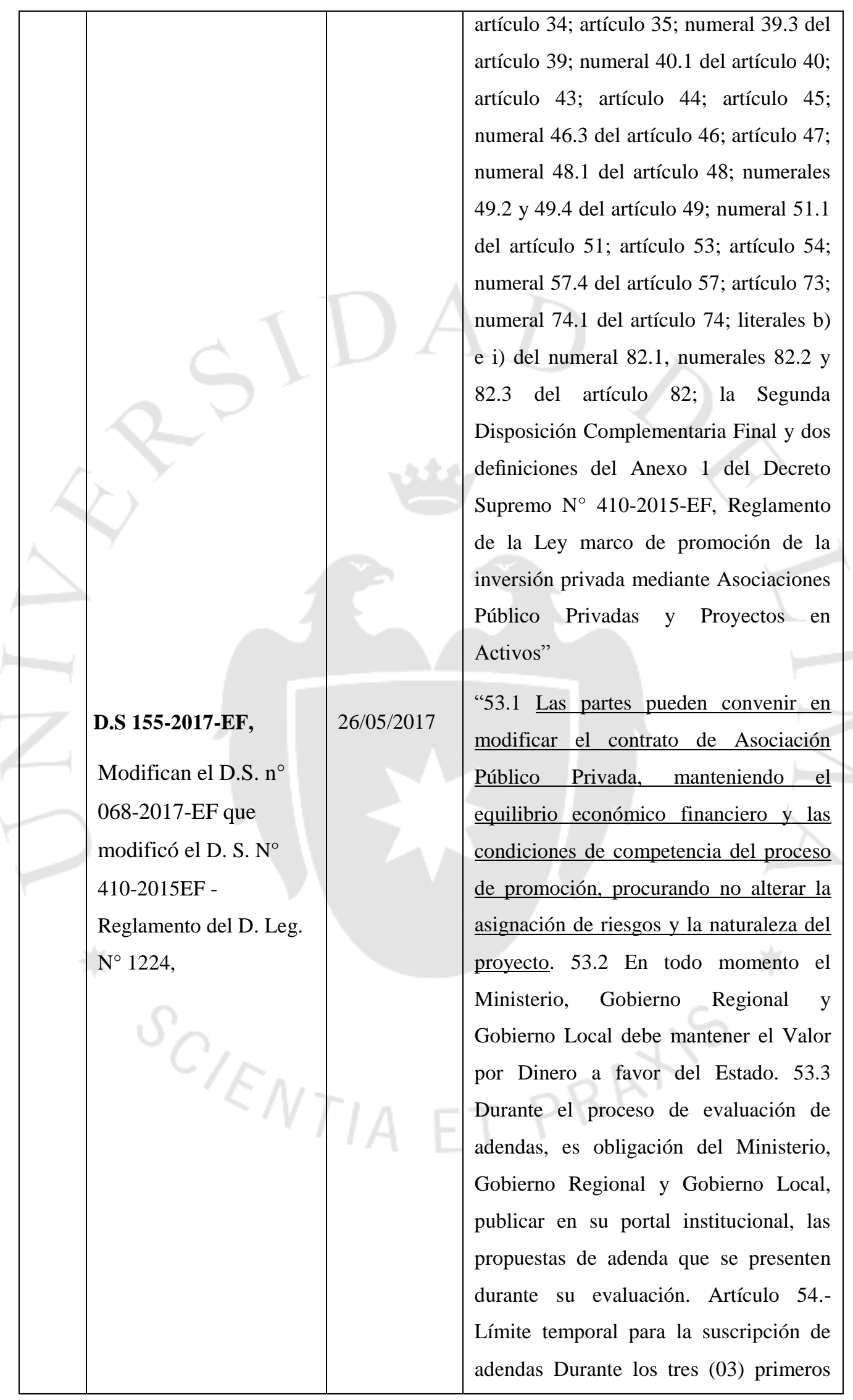




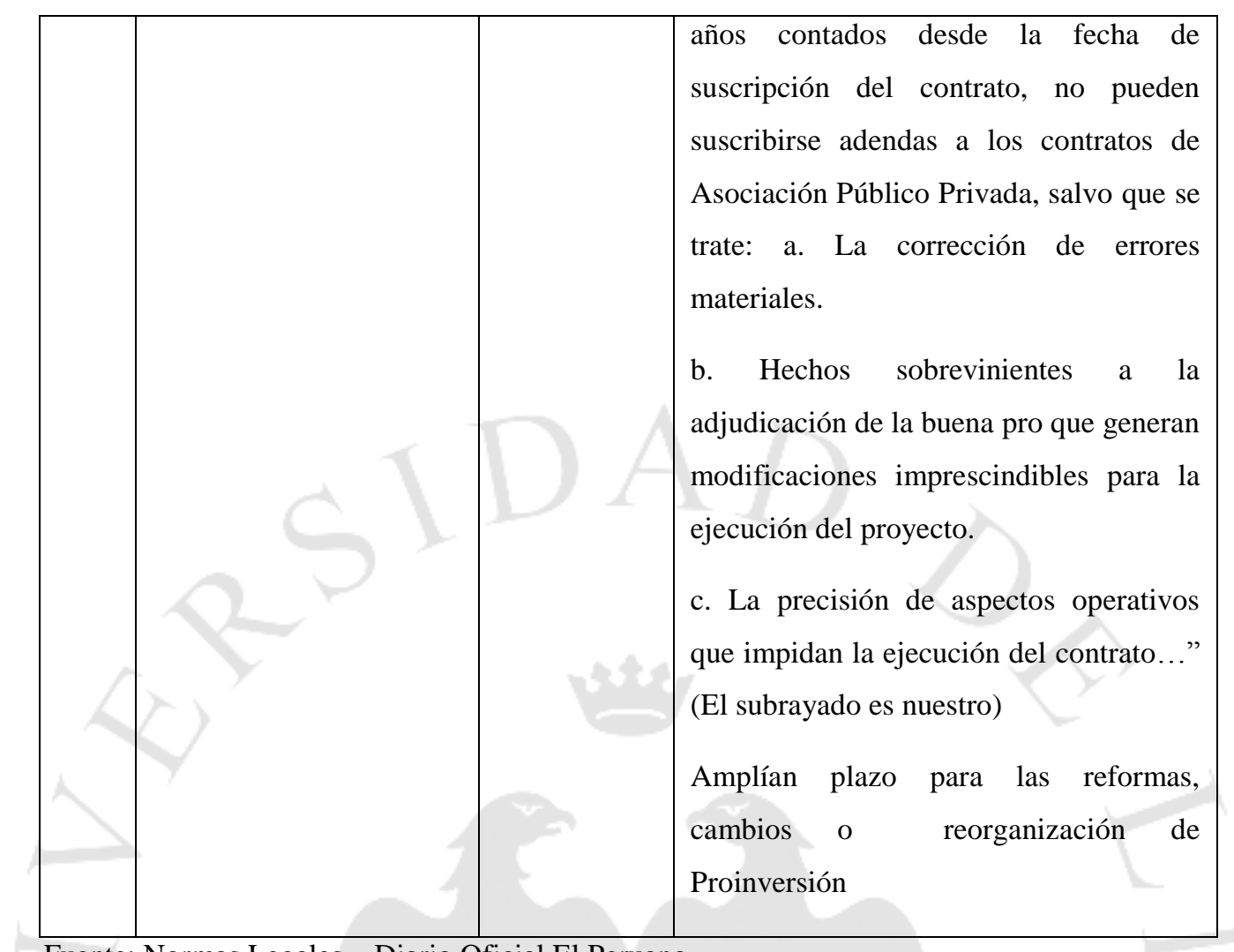

Fuente: Normas Legales - Diario Oficial El Peruano

Conforme advertimos, es a partir del 25 de setiembre del 2015, al emitirse el Decreto Legislativo $\mathrm{N}^{\mathrm{0}} 1224$ - Ley Marco de Promoción de la Inversión Privada mediante Asociaciones Público Privadas y Proyectos en Activos; y posteriormente su Reglamento aprobado por Decreto Supremo n. ${ }^{\circ}$ 410-2015-EF que se consolida y renueva la legislación sobre APP, la cual se encontraba dispersa y había sufrido varias modificaciones.

Consideramos que principalmente responde a la delegación que se le otorgó al Poder Ejecutivo el de poder legislar en materia administrativa, económica y financiera, estableciéndose como una de las prioridades de gobierno el promover, fomentar y agilizar la inversión público y privada así como las APP. (Ley N. ${ }^{\circ} 30335,2015$ )

Respecto a las modificaciones contractuales, éstas siempre han estado reguladas, teniendo las partes la potestad de modificar el contrato de Asociación Público Privada, por cuanto las adendas son justificables en un proceso de inversión pública a largo plazo; ello siempre y cuando se mantenga el equilibrio económico financiero y las condiciones de competencia del proceso de promoción, no debiendo alterar las adendas la asignación de riesgos y la naturaleza del proyecto. 
Hoy por hoy, la normativa habla de “... procurando no alterar la asignación de riesgos y la naturaleza del proyecto". (Decreto Supremo N 068-2017-EF, 2017); redacción normativa que resulta subjetiva e interpretativa, ya que tanto el Concedente como el Concesionario podrían interpretar que si ello se da, sería permisible legalmente. A nuestro entender, sin embargo, ello trastoca la esencia del Contrato de APP; por cuanto, son justamente - la naturaleza del proyecto y la distribución de riesgos - que el Estado define previamente a contratar, la que no puede modificar no pudiendo disponer que con posterioridad que el proyecto se realice por Obra pública; o caso contrario, que se modifique la distribución de riesgos, pudiendo conllevar un mayor costo no previsto para el Estado.

De otro lado, respecto al límite temporal para la suscripción de las adendas, ello ya venía siendo reglado desde el 2014, precisándose que "Durante los primeros tres (3) años contados desde la fecha de su suscripción, las entidades no podrán suscribir adendas a los contratos de Asociación Público Privada, salvo que se tratara de:

a) La corrección de errores materiales;

b) Los requerimientos sustentados de los acreedores permitidos vinculados a la etapa de cierre financiero del contrato.

c) La precisión de aspectos operativos que impidan la ejecución del contrato..." (Decreto Supremo N 127-2014-EF, 2014)

En este orden de ideas, es conveniente comentar que en la actualidad, se mantiene el rigor en el límite temporal para la suscripción de las adendas, solo se ha efectuado un cambio en los supuestos por los cuales es permitida la modificación contractual “... b) Los requerimientos sustentados de los acreedores permitidos vinculados a la etapa de cierre financiero del contrato....”; por “... b) Hechos sobrevinientes a la adjudicación de la buena pro que generan modificaciones imprescindibles para la ejecución del proyecto...." (Decreto Supremo N 068-2017-EF, 2017). Con lo cual se deja sin efecto la posibilidad de adendas por temas de bancabilidad.

\subsubsection{Principales cambios en la normativa de APP}


Al respecto, es importante resaltar los principales cambios que se han dado en el marco normativo de las APP; así tenemos

\section{Tabla 1.3.}

Principales cambios que se han dado con la nueva legislación de APP

\begin{tabular}{|c|c|}
\hline Tema & Que se incorpora \\
\hline $\begin{array}{l}\text { Política Nacional de Promoción } \\
\text { de la inversión privada en APP y } \\
\text { Proyectos en Activos. }\end{array}$ & $\begin{array}{l}\text { Se crea un instrumento de Política Nacional Ad } \\
\text { Hoc para APP que rige de manera transversal para } \\
\text { todas las entidades que conforman el Sistema } \\
\text { Nacional de Promoción de la Inversión Privada } \\
\text { liderado por el Ministerio de Economía y Finanzas - } \\
\text { MEF; constituyendo la base para que se logre una } \\
\text { mayor y más eficaz utilización de las APPs y } \\
\text { Proyectos en Activos en aras de brindar la } \\
\text { infraestructura y los servicios que la población del } \\
\text { país requiere; y lograr un crecimiento económico } \\
\text { inclusivo y sostenido. Para ello, el Estado debe } \\
\text { generar las condiciones adecuadas a nivel político, } \\
\text { normativo, institucional, social y económico, entre } \\
\text { otros, que favorezcan el cumplimiento de los } \\
\text { objetivos establecidos en la presente política } \\
\text { nacional. }\end{array}$ \\
\hline $\begin{array}{l}\text { Sistema Nacional de Promoción } \\
\text { de la Inversión Privada }\end{array}$ & $\begin{array}{l}\text { El MEF establece la política de promoción de la } \\
\text { inversión privada. Siendo la Dirección General de } \\
\text { Política de Promoción de la Inversión Privada - } \\
\text { DGPPI del MEF el ente rector del Sistema Nacional } \\
\text { de Promoción de la Inversión Privada quien emite } \\
\text { opinión exclusiva y excluyente sobre la } \\
\text { interpretación y aplicación del decreto legislativo } \\
\text { N. } 1251 \text { y sus disposiciones. Proinversión emite } \\
\text { directivas técnico normativas respecto del proceso } \\
\text { de evaluación de las APP en la fase de formulación, } \\
\text { estructuración y transacción así como para } \\
\text { Proyectos en activos. }\end{array}$ \\
\hline Opiniones previas a la versión & $\begin{array}{l}\text { Mayor rigurosidad en cuanto a su otorgamiento de } \\
\text { opiniones previas; precisándose que la opinión }\end{array}$ \\
\hline
\end{tabular}




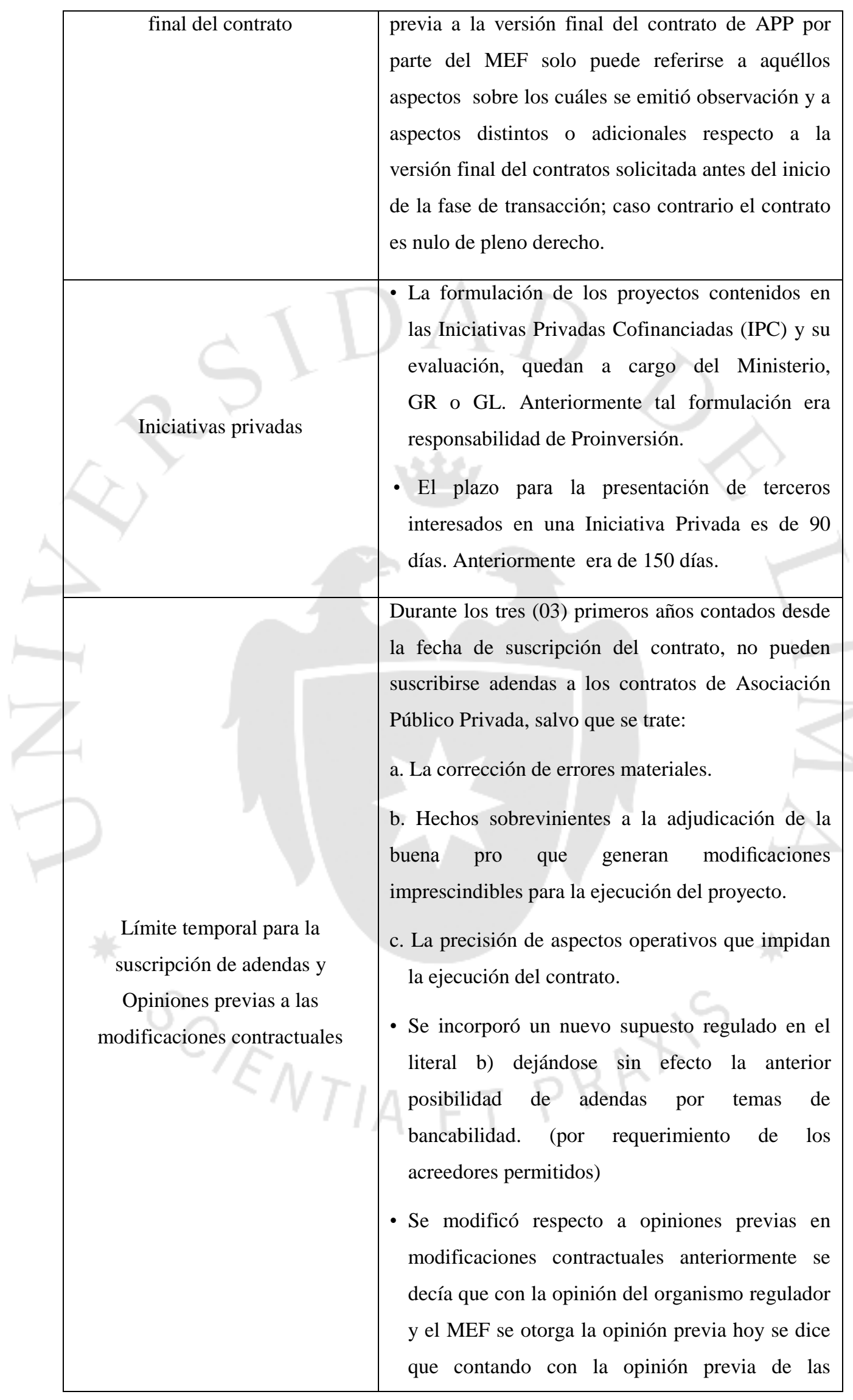




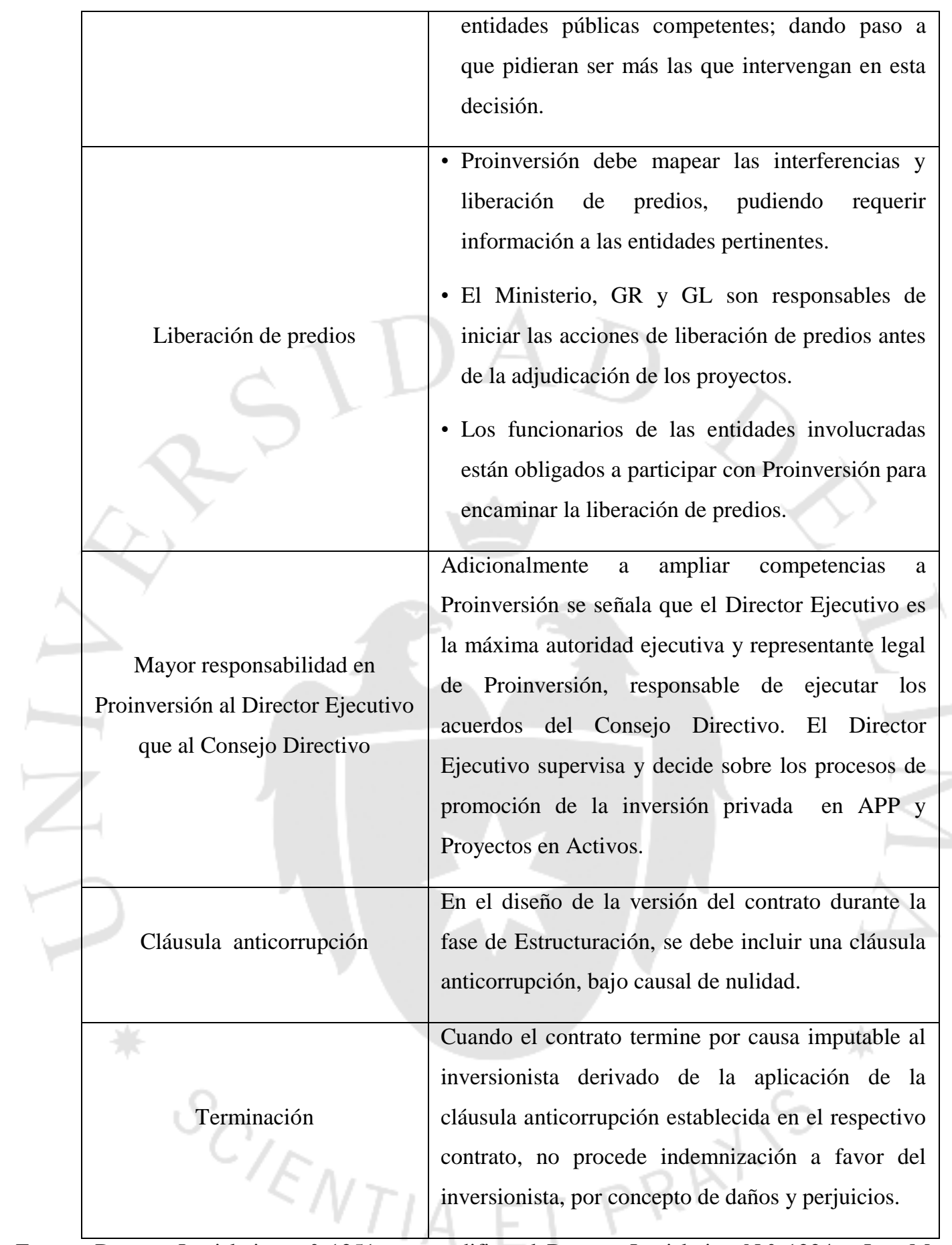

Fuente: Decreto Legislativo n. ${ }^{\circ} 1251$ que modifica el Decreto Legislativo N. ${ }^{\circ} 1224$ - Ley Marco de Promoción de la Inversión Privada mediante APP y Proyectos en Activos. (2016); y el Decreto Supremo $\mathrm{N}^{\circ}$ 068-2017-EF, que modifican el Decreto Supremo $\mathrm{N}^{\circ}$ 410-2015EF, Reglamento del Decreto Legislativo $\mathrm{N}^{\circ}$ 1224.(2017) 
Es de indicar, que en atención a la décimo cuarta Disposición Complementaria Final del Decreto Legislativo N. ${ }^{\circ}$ 1224, Ley Marco de Promoción de la Inversión Privada mediante APP y Proyectos en Activos, el Ministerio de Economía y Finanzas (MEF) aprobó la Política Nacional de Promoción de la inversión privada en APP y Proyectos en Activos. Sin embargo, consideramos que esta labor, debió ser asumida en su oportunidad por el Ceplan a través de la Política Nacional de Modernización de la Gestión Pública pero entendemos que ante el avance tan silencioso de la planificación estratégica en el país; es que el Ministerio de Economía y Finanzas (MEF) lideró esta estrategia más acotada y focalizada solo a APP y Proyectos en Activos como diseño de política nacional que opera de manera trasversal para todas las entidades públicas que conforman el Sistema Nacional de Promoción de la Inversión Privada.

Sin embargo, esta estrategia debe inyectar para que la política Nacional como país vaya avanzando, en aras de tener un norte claro que pueda trascender gobiernos; y a su vez, oriente la visión del Estado en su crecimiento en inversión pública, identificando los cuellos de botella a fin de alcanzar los resultados esperados como país. En este sentido, se hace necesario que se ponga énfasis en lo que constituye uno de los principios rectores de la política de la inversión privada en APP, el "Enfoque de resultados" y "valor por dinero", por lo que no únicamente debe tenerse en cuenta el control de las operaciones (insumos y procesos) y la efectividad de los recursos públicos que se invierten; sino que a su vez, buscar que los mismos contribuyan a generar beneficio en el ciudadano.

De otro lado, debemos estar alertas al rol de competencias que viene teniendo Proinversión y el Ministerio de Economía y Finanzas (MEF). Si bien se ha logrado definir sus funciones; el MEF como ente rector de la política Nacional en temas de APP desarrolla aspectos de planificación estratégica que sobrepasan sus competencias presupuestales y en los que principalmente deban participar los sectores. Aunado a ello, consideramos que el haber otorgado mayor responsabilidad en Proinversión al Director Ejecutivo que al Consejo Directivo, genera un cuello de botella y un alto nivel de responsabilidad para un solo funcionario que difícilmente puede advertir temas técnicos a detalle en los procesos de promoción de la inversión privada en APP, previamente a aprobarlos. 
Al respecto, el titular del Ministerio de Economía y Finanzas, Thorne, A. (2017) refiriéndose a las modificaciones del Reglamento de las Asociaciones Pública Privadas, señaló dirigiéndose a la opinión pública:

Que el país tiene como visión desarrollar un programa de APP de largo plazo, con proyectos de calidad técnica y procesos innovadores con prácticas internacionales... Estamos desplegando una estrategia que se sostiene en dos pilares: (i) integridad y transparencia para garantizar la protección de los intereses de todos los peruanos, y (ii) eficiencia para la mejora de calidad y cantidad de adjudicaciones.

\subsubsection{Principales actores involucrados en el Sistema Nacional de promoción de la inversión privada}

El Sistema de Promoción de la Inversión Privada, es un sistema funcional para el desarrollo de las Asociaciones Público Privadas y Proyectos en Activos; integrado por principios, normas, procedimientos, lineamientos y directivas técnico normativas, con el fin de promover, fomentar y agilizar la inversión privada para contribuir a la dinamización de la economía nacional, la generación de empleo productivo y la competitividad del país (Decreto Legislativo N. ${ }^{\circ}$ 1251, 2016); encontrándose conformado principalmente por las siguientes entidades públicas: 
Figura 1.3.

Principales actores involucrados en el Sistema Nacional de promoción de la Inversión Privada

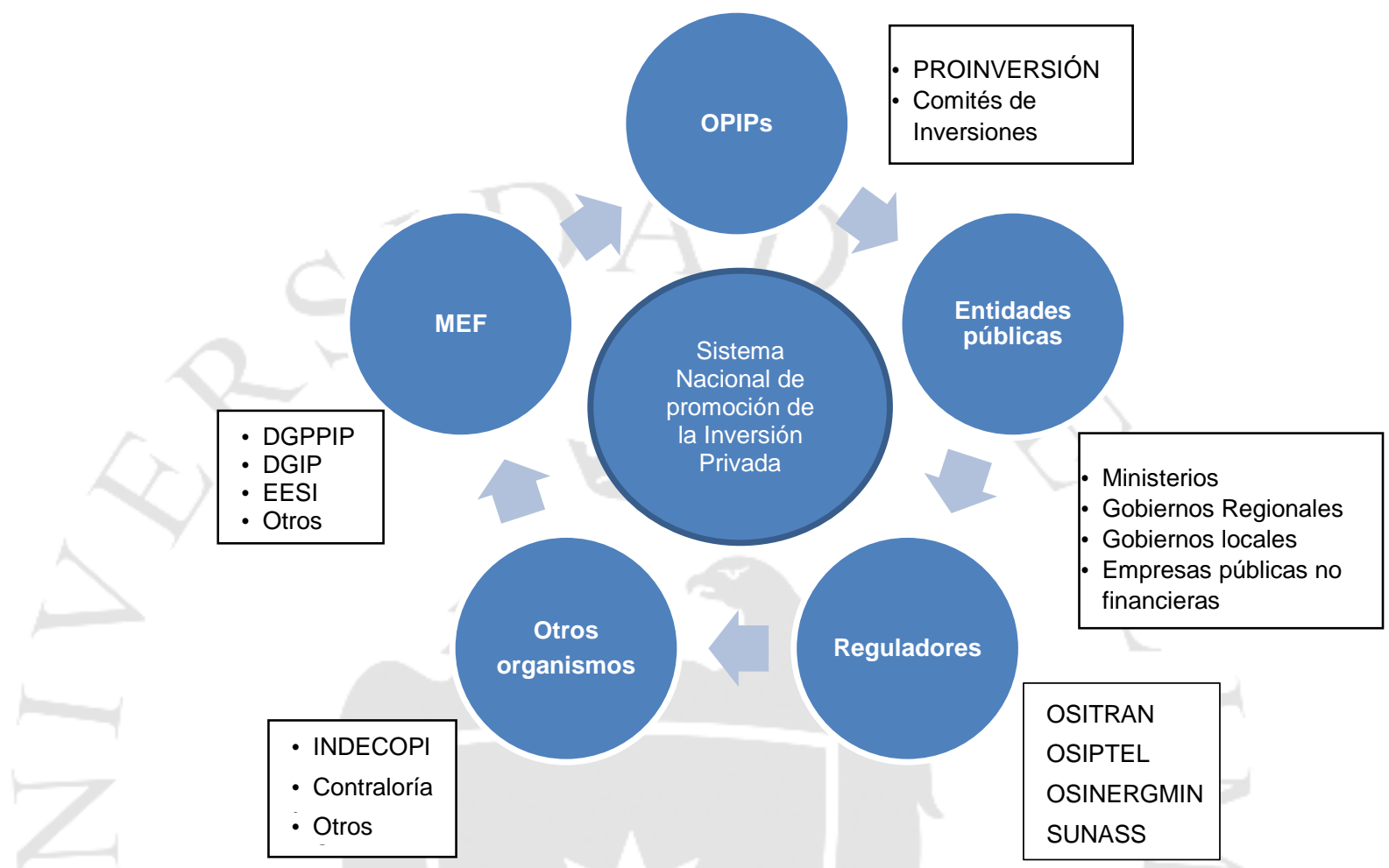

Fuente: Decreto Legislativo n. ${ }^{\circ} 1251$ que modifica el Decreto Legislativo N. ${ }^{\circ} 1224$ - Ley Marco de Promoción de la Inversión Privada mediante APP y Proyectos en Activos. (2016); y el Decreto Supremo $\mathrm{N}^{\circ}$ 068-2017-EF, que modifican el Decreto Supremo $\mathrm{N}^{\circ}$ 410-2015EF, Reglamento del Decreto Legislativo $\mathrm{N}^{\circ}$ 1224.(2017)

Para lo cual es importante tener en cuenta los principales roles de los actores involucrados en el Sistema Nacional de promoción de la inversión privada, los cuales se detallan a continuación:

Ministerio de Economía y Finanzas: Es quien establece la política de promoción de la inversión privada, siendo que la Dirección General de Política de Promoción de la Inversión Privada (DGPPIP) el Ente rector del Sistema Nacional de Promoción de la Inversión Privada; y tiene entre otros las siguientes competencias:

- Formula y propone la política nacional para el desarrollo y promoción de las APP y Proyectos en Activos. 
- Dicta lineamientos técnico normativos sobre aspectos establecidos en la Ley y el Reglamento.

- Emite opinión exclusiva y excluyente con carácter de vinculante sobre el alcance e interpretación de las normas del Sistema Nacional de Promoción de la Inversión Privada.

- Evalúa el impacto de la implementación de la política nacional de Promoción de la Inversión Privada a través de APP y Proyectos en Activos.

- Fortalece capacidades y brinda asistencia técnica a los integrantes del Sistema Nacional de Promoción de la Inversión Privada.

- Administra el Registro Nacional de Contratos de APP.

Como se observa, el Ministerio de Economía y Finanzas es la entidad encargada de asegurar la implementación de la presente política nacional coordinando con las demás entidades que conforman el Sistema Nacional de Promoción de la Inversión Privada en aras de alcanzar los objetivos propuestos. (Decreto Supremo n. ${ }^{\circ}$ 068-2017-EF, 2017)

Organismos Promotores de la Inversión Privada - OPIP: Para el caso del Gobierno Nacional es la Agencia de Promoción de la Inversión Privada - Proinversión para los proyectos que se asignen en función de su relevancia nacional y los Ministerios a través del Comité de Inversiones. Cuando se trata de proyectos de Gobiernos Regionales y Gobiernos Locales, las facultades del Organismo Promotor de la inversión privada se ejerce en forma directa a través del Comité de inversiones. El órgano máximo de estos Organismos promotores de la Inversión Privada es el Consejo Regional o Consejo Municipal. Siendo que los Ministerios, Gobiernos Regionales y Locales pueden encargar el proceso de promoción a Proinversión, así como solicitarles asistencia técnica en cualquiera de las fases del proceso (Decreto Legislativo N. ${ }^{\circ} 1224$, 2015)

Agencia de Promoción de la Inversión Privada - Proinversión: Organismo técnico especializado adscrito al Ministerio de Economía y Finanzas; a su vez es Organismo Promotor de la Inversión Privada del Gobierno Nacional, de los proyectos de relevancia nacional; así como de aquellos cuya conducción del proceso de 
promoción de la inversión privada es encargada por el Ministerio, Gobierno Regional o Gobierno Local. Tiene entre sus principales competencias:

- Ejecutar la política nacional de promoción de la inversión privada.

- Elabora el Informe de Evaluación de los proyectos a su cargo.

- Analiza y declara de interés las iniciativas privadas, cofinanciadas y autofinanciadas e iniciativas privadas; así como aquellas sobre proyectos en activos a su cargo.

- Conduce el proceso de evaluación conjunta de modificaciones contractuales en los casos que corresponda.

- Emite conformidad a los documentos que sustenten el endeudamiento garantizado permitido o Cierre permitido o análogos cuando corresponda.

- Realiza el acompañamiento en la fase de ejecución contractual en los proyectos de inversión que se desarrollen bajo cualquiera de los mecanismos regulados en la Ley o el Reglamento.

- Ejecuta programas de fortalecimiento de capacidades y asistencia técnica a los integrantes del Sistema Nacional de Promoción de la Inversión Privada.

Proinversión tiene oficinas descentralizadas y está integrado por el Consejo Directivo, la Dirección Ejecutiva y los Comités Especiales de Inversiones (Decreto Supremo n. ${ }^{\circ}$ 068-2017-EF, 2017)

Organismos Reguladores: Tratándose de proyectos en sectores regulados, la supervisión se sujeta a lo dispuesto por la Ley Marco de los Organismos Reguladores de la Inversión privada en los servicios públicos y normas vigentes. Estableciéndose como Organismos reguladores a: Organismo Supervisor de la Inversión Privada en Telecomunicaciones (Osiptel); Organismo Supervisor de la Inversión en Energía y Minería (Osinergmin); Organismo Supervisor de la Inversión en Infraestructura de Transporte de Uso Público (Ositran); y Superintendencia Nacional de Servicios de Saneamiento (Sunass). En los demás casos, los Contratos de APP incorporan expresamente la entidad pública competente, para el ejercicio de la función supervisora. 
Contraloría General de la Republica - CGR: Este ente técnico rector interviene expresamente a través de las normas de APP con la emisión de su Informe Previo respecto a la versión final del Contrato de Asociación Público Privadas únicamente sobre aquellos aspectos que comprometan el crédito o la capacidad financiera del estado, de conformidad con el inciso 1) del artículo $22^{\circ}$ de la Ley $\mathrm{N}^{\circ}$ 27785, Ley Orgánica del Sistema Nacional de Control y de la Contraloría General de la República, siendo que dicho Informe no es vinculante sin perjuicio del control posterior que se ejerce a través del control gubernamental.

Al respecto, la Contraloría General de la República (CGR, 2015) señala que:

La Contraloría interviene en los procesos de promoción de la inversión privada para ejercer el control gubernamental (previo, simultáneo o posterior) de los proyectos de APP. En esa línea este órgano superior de control se pronuncia sobre aquellos aspectos que comprometan el crédito o la capacidad financiera del Estado, según lo dispuesto en el literal i) del artículo $22^{\circ}$ de su Ley Orgánica. (p. 106)

Como advertimos el rol que ejerce la CGR en el Sistema Nacional de Promoción de la inversión privada, está dado desde un control preventivo y a su vez desde un control posterior (sancionador), lo cual analizaremos en el segundo capítulo de este trabajo.

\subsection{Importancia de la implementación de una APP y por qué seguir apostando por ellas?}

Es importante considerar que sin importar qué lugar del mundo visitemos, la infraestructura es la piedra angular del bienestar económico y social. La infraestructura sustenta el transporte eficiente de personas y productos; suministra servicios esenciales como agua, saneamiento y electricidad; por lo que en un país con carencias sostenidas de inversión en infraestructura, la competitividad económica puede verse afectada. Estableciéndose que la "brecha de infraestructura" global es tan grande que para cerrarla en el año 2030 serán necesarios aproximadamente de 70 billones de dólares²;

\footnotetext{
${ }^{2}$ Entre el 2015 y 2025, los países alrededor del Mundo invertirán en conjunto alrededor de US\$ 6 a 9 billones de dólares anuales $-8 \%$ del PBI global en proyectos de infraestructura de gran envergadura. Para el 2030 según estimaciones de la Organización para la Cooperación y el desarrollo Económico
} 
situación que se agrava si tenemos en cuenta que los ingresos del gobierno son restringidos y los gastos en el sector público están constantemente siendo fiscalizados. En estas condiciones hoy más que nunca es importante adquirir la infraestructura adecuada cobrando importancia las Asociaciones público privadas. (EY Building a better working world, 2016, p.12)

Como advertimos, la globalización y la brecha de infraestructura que existe en los países, crea un escenario perfecto que otorga importancia al modelo económico de las APP. A ello, se suma que el Estado no ha logrado garantizar servicios públicos básicos a la ciudadanía de manera satisfactoria ${ }^{3}$. Es así que en torno a esta coyuntura, Casado Cañeque (2007) precisa:

Uno de los principales retos de nuestro tiempo es poder crear un nuevo concepto de desarrollo que pueda superar estos límites de gestión y gobernanza que limitan el progreso humano y condicionan el acceso a las comunidades pobres a los bienes y servicios públicos. Para ello, es necesario establecer instituciones públicas fuertes y efectivas que puedan promover e incentivar a los otros actores (sector privado $\mathrm{u}$ organizaciones sociales) de manera que se canalicen los recursos eficientemente y se promuevan soluciones conjuntas, ya que los problemas son demasiados complejos e interdependientes para que un actor solo pueda resolverlos individualmente. En ese sentido, las alianzas público privadas y las alianzas para el desarrollo pueden ser mecanismos importantes para poder gestionar mejor las carencias del mercado y las ineficiencias públicas de manera que se garanticen los bienes y servicios públicos. No son siempre el sistema más eficaz, ni serán nunca fáciles de implementar. Casi siempre implican altos costes de transacción y son difíciles de gestionar y de hacerlas

(OCDE) la infraestructura requerida en transporte, electricidad, agua y telecomunicaciones será superior a los US\$70 billones. El Perú no será ajeno a esta necesidad de realizar inversiones importantes en infraestructura para atender la demanda creciente por mejores servicios públicos, vías de comunicación y centros logísticos de un país en rápido crecimiento.

3 Si bien ha existido desde el 2002 una reforma del Estado en el proceso de modernización de la Gestión Pública, en donde ha pasado de ser un Estado estático, poco flexible a un Estado entre otros, moderno, abierto, inclusivo y eficiente en busca de resultados, en donde tiene apertura para solicitar apoyo al sector privado en aras de mejorar sus servicios; sin embargo, el avance es lento ya sea por su ineficiencia, alta burocracia en los procesos que dificultan su gestión, por carencia de capacidades o de recursos económicos. Lo cual viene dificultando también el éxito en la implementación de las APP en nuestro país. 
sostenibles; pero sin embargo son una herramienta necesaria e imprescindible que asegura un crecimiento económico. (pp. 30-31)

Sin perjuicio de lo expuesto, es importante entender, que esta novedosa forma de contratar a través de APP es sumamente atractiva y no "porque se encuentre de moda" en todos los casos el Estado peruano deba implementarla. Por ello, surge la necesidad de contar con un Estado que pueda previamente definir a través de una planificación estratégica en todos los sectores y en los tres niveles de gobierno, cuáles serán en el período presupuestal los proyectos de inversión que se priorizará en función a la necesidad que se pretende atender y satisfacer en el ciudadano; sin importar cuál será la modalidad a contratar (APP, Obra pública, etc).

Esta evaluación integral y aprobación de los proyectos que deben ejecutarse en función a la política nacional a largo plazo, teniendo en cuenta los objetivos y metas como Estado; permitirá no solo tener un norte claro de las prioridades estratégicas como Estado y del gasto público, sino también evitaría que las prioridades de política pública se distorsionen o cambien a favor de aquellos proyectos de iniciativa privada que resulten más atractivos, que podrían ser útiles pero no son prioritarios, y que no necesariamente respondan a intereses públicos sino privados.

Es por ello, que resulta vital tener en cuenta, que cuando nos referimos a las iniciativas privadas debemos considerar la precisión que hace Morón Urbina (como se citó en Vilcanqui Velásquez, 2012) que:

Se originaron en la necesidad de servicios e infraestructura que el Estado no puede satisfacer y por ello, reconoce esta facultad de los particulares de identificar prioridades y proponer ideas suficientemente estudiadas sobre servicios públicos e infraestructura, que siendo interés del proponente también sea de intereses generales, socialmente rentables, sostenibles y concordantes con la política de Estado. (p. 294)

Aunado a lo expuesto, también resulta importante para el éxito de la implementación de una APP y que pueda generar el valor que se le exige, contar con un Estado que esté representado por funcionarios públicos que puedan gestionar procesos eficientes, y competitivos, y como resultado de ello, se incremente la inversión e iniciativas 
privadas. No solo es contar con marcos normativos que busquen ser estables y predecibles a largo plazo sino también mejorar en la ejecución contractual de los proyectos de inversión que se vienen dando en nuestro país.

\subsubsection{Análisis de las bondades de una APP.}

La APP produce beneficios para ambas partes, por un lado las empresas obtienen beneficios; y por otro lado el Estado provee de servicios públicos que de realizarlos el mismo traería mayor gasto público y mucha insatisfacción social por un servicio inadecuado. En cambio, el Estado al trasladar la prestación del servicio al particular puede elegir entre una gama de postores la mejor opción competente, para la prestación del servicio. Por lo expuesto, se tiene como principales bondades:

- La capacidad de proveer un servicio a un menor costo y menor tiempo, exigiendo que no lesione la calidad del mismo.

- Mejora de los servicios públicos y la posibilidad de garantizar buenos niveles de servicio por largos períodos.

- Una gestión más eficiente de los riesgos del proyecto.

- La capacidad de atraer innovación tecnológica y otorgar flexibilidad a la provisión de servicios.

- En algunos casos la estructuración financiera de un proyecto puede atraer recursos financieros en condiciones más favorables que si se realizara como un proyecto público. (BID, 2011, p.30)

Las APP tienen una amplia gama de modalidades para elegir, acorde al proyecto a desarrollarse puede ser en forma de concesión, gestión, asociación en participación, riesgo compartido o cualquier modalidad contractual permitida por ley ${ }^{4}$. Es así que tenemos:

\footnotetext{
${ }^{4} \mathrm{El}$ actual Reglamento que regula las APP aprobado mediante Decreto Supremo N. ${ }^{\circ}$ 410-2015-EF (2015), en su numeral 11.4, precisa:
} 
Tabla 1.4.

Principales bondades de las APP

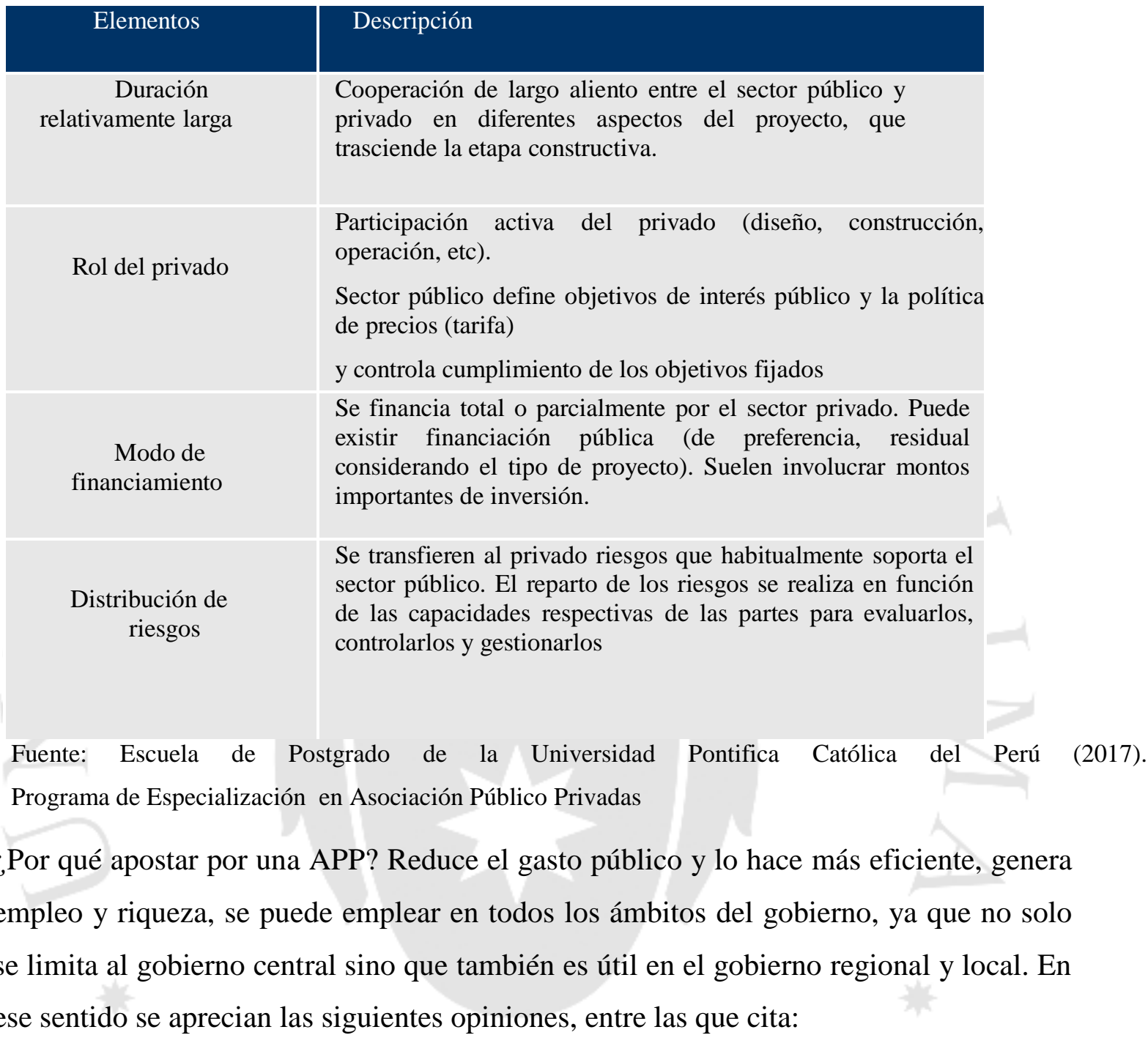

$\mathrm{Al}$ respecto, Ian Cruz, consultor del Banco Mundial y experto en APP, asegura que este esquema es beneficioso porque permite hacer eficiente el gasto.

Comentó que México pudo, en diez años, desarrollar APP en todas sus provincias, centrándose en infraestructura para el sector salud como hospitales y postas médicas.

Las modalidades de Asociación Público Privada incluyen todos aquellos contratos en los que se propicia la participación activa del sector privado y se le transfieren riesgos; además en los que la titularidad de la infraestructura pública, según sea el caso, se mantiene, revierte o transfiere al Estado. De manera enunciativa, pueden ser concesión, operación y mantenimiento, gestión, así como cualquier otra modalidad contractual. 
Este trabajo, precisa, implicó fortalecer las capacidades para generar carteras atractivas a la inversión privada, mejorar los procesos administrativos del Estado a todo nivel y vincular este instrumento con las políticas de desarrollo de competitividad regional y local.

Sergio Bravo, director del Instituto de Regulación y Finanzas de la Universidad ESAN, señala que se espera concretar más obras de desarrollo a través de este mecanismo, dado que hay inversionistas en diversos sectores, como en carreteras. (Bessombes, C., 2013, párr.8-11):

En líneas generales, apostar por una APP, produce:

- Generación de empleo

- Satisfacción del servicio público por parte de la ciudadanía

- $\quad$ Agiliza la prestación del servicio

- $\quad$ Reducción del gasto público

- $\quad$ Mejora de la infraestructura nacional, regional y local

- $\quad$ No debe conllevar pérdidas económicas para el Estado

- Debe erradicar las trabas burocráticas en la prestación de servicios; por cuanto perjudica el resultado esperado.

- Mayor productividad y mejora de la economía nacional

- $\quad$ Incremento de la inversión privada nacional y extranjera

- Genera un ambiente de seguridad económica y financiera en la inversión privada

- $\quad$ Ofrece la posibilidad de elegir la mejor opción dentro de una gama de inversionistas, en atención a sus capacidades.

Es por ello, importante tener en cuenta estas bondades que tienen las APP que si son bien gestionadas tendrán el potencial de generar el valor que se les exige para los proyectos; sin embargo, debe tenerse en cuenta que es una herramienta útil para una serie de objetivos concretos; no debiera planteársele como un fin en sí misma sino como 
un proceso para conseguir resultados positivos en el logro de los Objetivos de Desarrollo como país. (Casado, 2007, p.12)

Por ello, previamente a su implementación en un proyecto de inversión se debe evaluar si resulta conveniente ejecutarlo por APP o por Obra pública con el tradicional sistema, del cual existen principales diferencias, que se detallan a continuación:

Tabla 1.5

Diferencia entre el Contrato de Obra Pública y el Contrato de Concesión (APP)

\begin{tabular}{|c|c|c|}
\hline & OBRA PÚBLICA & CONCESIÓN (APP) \\
\hline Definiciones & $\begin{array}{l}\text { Entrega de un bien, suministro, o servicio determinado } \\
\text { por la colectividad pública }\end{array}$ & $\begin{array}{l}\text { Construcción de un equipamiento y gestión de un servicio } \\
\text { público por un concesionario privado, mediante un acuerdo } \\
\text { entre la parte pública y la parte privada }\end{array}$ \\
\hline $\begin{array}{l}\text { Principales } \\
\text { caracteristicas }\end{array}$ & $\begin{array}{l}\text { - Objeto único, usualmente solo construcción } \\
\text { - Corta duración } \\
\text { - No se asocia a la gestión del servicio } \\
\text { - No se le delega una misión pública }\end{array}$ & $\begin{array}{l}\text { - Objeto múltiple, construcción, operación, y mantenimiento a } \\
\text { largo plazo. } \\
\text { - Larga duración } \\
\text { - Se asocia a la gestión del servicio } \\
\text { - Se le delega una misión pública }\end{array}$ \\
\hline $\begin{array}{l}\text { Caracteristicas } \\
\text { esenciales }\end{array}$ & $\begin{array}{l}\text { - Dirección de la realización a cargo de una entidad } \\
\text { pública } \\
\text { - No hay prefinanciamiento, cofinanciamiento ni } \\
\text { financiamiento de la obra por parte del contratista } \\
\text { - No hay inversión del contratista } \\
\text { - No hay libertad de concepción del servicio o de la obra } \\
\text { - El contrato no crea ni organiza el servicio } \\
\text { - El contratista no es el propietario } \\
\text { - No hay libertad de gestión del contrato para la empresa } \\
\text { - No hay ocupación del dominio público por largo tiempo } \\
\text { - No hay responsabilidad mixta por obras, su gestión y } \\
\text { conservación }\end{array}$ & $\begin{array}{l}\text { - Dirección de las operaciones a cargo del concesionario } \\
\text { - Prefinanciamiento, cofinanciamiento o financiamiento de la } \\
\text { obra por parte del concesionario } \\
\text { - La inversión corre por cuenta del concesionario } \\
\text { - Libertad total o parcial de concepción del servicio o de la } \\
\text { obra } \\
\text { - El contrato instituye y organiza el servicio deseado por la } \\
\text { colectividad } \\
\text { - El concesionario es el titular o propietario } \\
\text { - Libertad de gestión del contrato por parte del concesionario } \\
\text { - En general, hay ocupación del dominio público por largo } \\
\text { tiempo }\end{array}$ \\
\hline
\end{tabular}

Fuente: Escuela de Postgrado de la Universidad Pontifica Católica del Perú (2017). Programa de Especialización en Asociación Público Privadas

\subsubsection{Problemática o barreras para la ejecución de APP - Renegociaciones}

Consideramos que entre las principales dificultades que enfrentan las APP en su implementación, tenemos:

- La creatividad o grado de discrecionalidad que debe existir en los proyectos de inversión, se ve amenazada o limitada por solo el cumplimiento de la legalidad en la gestión.

- Escasa capacitación a funcionarios públicos, conlleva frente a temas complejos ineficiencia estatal.

- $\quad$ En su mayoría los proyectos no cuentan con adecuados estudios, que permitan advertir que la implementación de la APP era la solución. 
- $\quad$ Problemas con las expropiaciones y liberación de terrenos, que conlleva retrasos y renegociaciones.

- Constante variación del marco regulatorio de APP, que hace que percibir, una nivel de estabilidad, y que pueda ser predecible a lo largo del tiempo.

Muchas de estas limitaciones, han motivado que el Estado tenga que realizar modificaciones contractuales, renegociaciones, estableciendo la Contraloría General de la República (2015), que ante un inadecuado diagnóstico y priorización de problemas, formulación de muchos proyectos pequeños, inadecuada selección de modalidades y falta de recursos asignados a la operación y el mantenimiento han conllevado que entre los años 2000 al 2013 se hayan realizado un total de 103 adendas a los contratos de concesión; si bien la renegociaciones pueden ser un instrumento positivo cuando aborda aquellas circunstancias o vacíos no previstos por los contratantes; no obstante se presentan renegociaciones que no son eficientes y que son aplicadas por el comportamiento oportunista de las partes contrayentes, lo cual socaba la eficiencia de los proyectos y por ende con el bienestar social.(p. 19-20)

Al respecto, el titular del Ministro de Economía y Finanzas, Thorne, A. (2017) refiriéndose a la nueva modificatoria del Reglamento de las Asociaciones Pública Privadas, señaló dirigiéndose a la opinión pública: Se han introducido candados institucionales a la celebración indiscriminada de adendas, hoy existe un nuevo Sistema de APP, más técnico, por lo que refiere que ya no se asignarán "proyectos a dedo".

En ese sentido, es meritoria la opinión de Augusto de la Torre, economista jefe para América Latina y el Caribe del Banco Mundial, quien sostiene que

Respecto a las renegociaciones que a veces solicita el privado, refirió que es importante que el Estado cuente con sistemas de solución de controversias. "Muchas de estas (renegociaciones) surgen porque son contratos de 15 a 20 años en los que el sector privado se queja, llora y renegocia. Uno de los problemas más típicos de las APP es que una vez que se adjudicaron, en los siguientes años la empresa que ha ganado renegocia y renegocia, pide adendas. (Elegir con cuidado la modalidad con que se adjudican las concesiones evita que el privado pida adendas, 06 de noviembre de 2015, Gestión, párr. $8)$. 
Es por ello, que mediante la dación del Decreto Supremo N. ${ }^{\circ}$ 068-2017-EF ${ }^{5}$, que modifica el Decreto Supremo N. ${ }^{\circ} 410-2015-E F$ Reglamento del Decreto Legislativo ${ }^{\circ}$ 1224, Ley Marco de Promoción de la Inversión Privada mediante Asociaciones Público Privadas y Proyectos en Activos; se ha incorporado un nuevo supuesto por "hechos sobrevinientes a la adjudicación de 1 buena pro que generen modificaciones imprescindibles para la ejecución del proyecto" dejándose sin efecto la anterior posibilidad de adendas por temas de bancabilidad. (por requerimiento de los acreedores permitidos).

Sin perjuicio de lo expuesto, es importante tener en cuenta los proyectos en ejecución principalmente del sector transportes; que es el sector que más ha sido beneficiado con la implementación contractual de las APP, proyectos que se detallan a continuación:

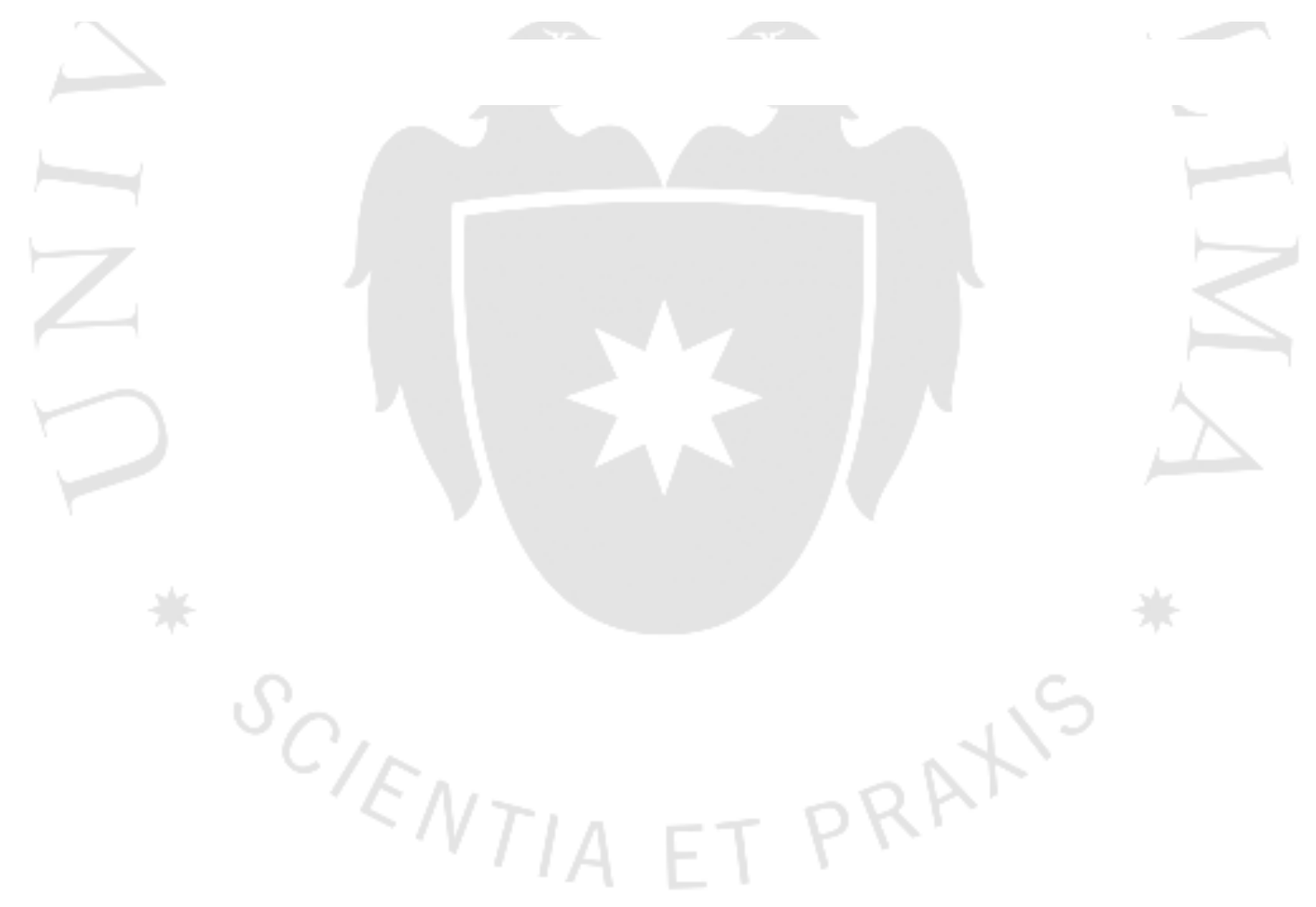

5 Cabe precisar que el Artículo 54 del Decreto Supremo N. ${ }^{\circ}$ 068-2017-EF, establece:

Límite temporal para la suscripción de adendas:

Durante los tres (03) primeros años contados desde la fecha de suscripción del contrato, no pueden suscribirse adendas a los contratos de Asociación Público Privada, salvo que se trate:

a. La corrección de errores materiales.

b. Hechos sobrevinientes a la adjudicación de la buena pro que generan medicaciones imprescindibles para la ejecución del proyecto.

c. La precisión de aspectos operativos que impidan la ejecución del contrato. 
Tabla 1.6.

Lista de proyectos en ejecución bajo la modalidad de APP, sector Transportes y Comunicaciones

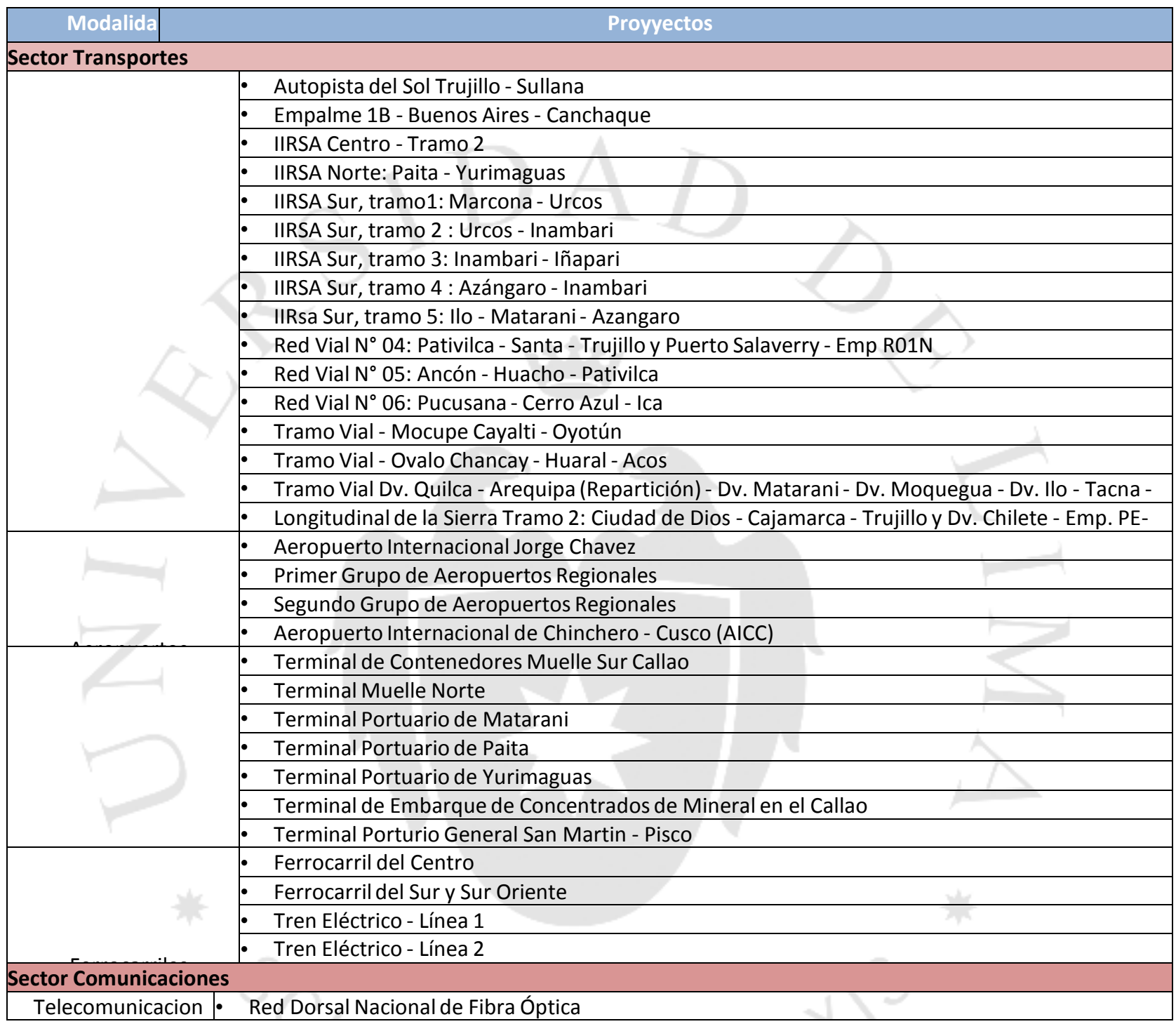

Fuente: Ministerio de Transportes y Comunicaciones. Informe Multianual de Inversiones 2016

No obstante ello, se observa que pese a las bondades que otorga la implementación de las APP en los proyectos de inversión existen pocos proyectos adjudicados del 2006 al 2016; siendo que para este último período (2016) solo contamos con uno, , conforme se grafica a continuación: 
Figura 1.4.

Proyectos APP adjudicados, $2006-2016^{1 /}$

(US\$ millones, incluye IGV)

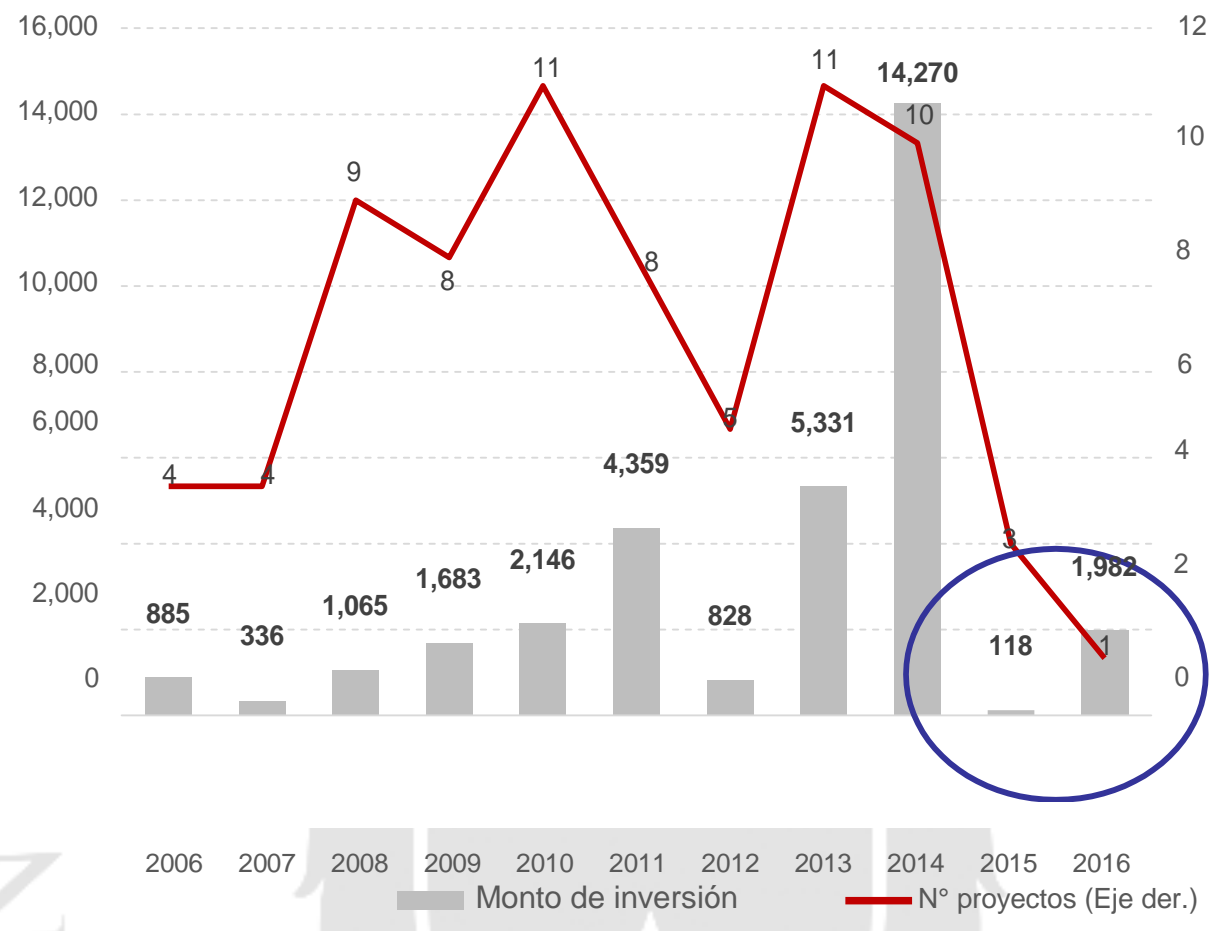

1/ Se agregó el IGV asumiendo que todo el monto de inversión están afectos al mismo. La inversión total incluye todos los montos que se gatillan por factores de demanda.

Fuente: PROINVERSIÓN y Escuela de Postgrado de la Universidad Pontifica Católica del Perú (2017). Programa de Especialización en Asociación Público Privadas

Asimismo, entre los períodos de enero 2008 a mayo 2017 solo se han adjudicado 13 proyectos de APP cofinanciadas, revisar anexo $\mathbf{N}^{\circ} \mathbf{0 1}$ del presente Trabajo.

\subsubsection{Resultados adversos en casos de coyuntura.}

En los últimos años se observan resultados adversos en casos de renegociaciones, en servicios públicos de coyuntura social, pese a los candados institucionales que se han considerado en el nuevo marco normativo de APP, pese a ello, las entidades públicas involucradas en el Sistema Nacional de Promoción de la Inversión Privada no vienen 
cumpliendo con sus funciones, conllevando retrasos y en otros casos parálisis de los resultados esperados por la población, casos que detallamos a continuación:

\section{Caso Aeropuerto Internacional Jorge Chávez:}

La modernización del Aeropuerto Jorge Chávez, proyecto de más de US\$ 1,200 millones, es una de las tantas mega obras paralizadas por la ineficiencia del Estado. Las Obras contemplan la construcción de una segunda pista de aterrizaje y un terminal adicional que permitirá atender la creciente demanda que en este momento recibe el Aeropuerto y que ya lo han llevado a un punto de colapso. (Laguna, M. 2016. Gestión, párr. 2). Sin embargo, a la fecha aún no se han retirado las interferencias de los terrenos sobre los cuales se llevará a cabo la construcción.

$\mathrm{Al}$ respecto, se cuestiona la suscripción de la adenda n. ${ }^{\circ} 07$ que es sumamente controversial pues estaría modificando la forma de remuneración del concesionario. Al respecto es el Ositran, la entidad que definirá si se modifica o no la fórmula de cálculo del factor de productividad que permitirá fijar las tarifas después del 2019, como parte de las renegociaciones. LAP ha expresado su necesidad de garantizar un flujo de ingresos que le permita facilitar su obtención del financiamiento necesario para ejecutar la ampliación del Aeropuerto; sin embargo, para Ositran es claro que los usuarios del aeropuerto solo deben pagar las tarifas que técnicamente se determine que corresponden a la prestación de los servicios; y no, asumir los costos generados por el retraso del Estado en la entrega de terrenos al concesionario. Las consecuencias de eso debe asumirlas el Estado, no los usuarios. Adicionalmente, el MTC viene negociando para que LAP cumpla con los plazos planteados por el MTC con lo cual se le extendería la concesión hasta el 2041; quedando en el MTC el compromiso de terminar de sanear los 7 millones de m2 necesarios para las obras eliminando las interferencias en el 2017 , garantizando de esta forma que no habrá más demoras. Las dudas giran, nuevamente, en torno a la capacidad del concesionario para obtener los US\$1.200 millones necesarios para financiar los trabajos. (Hurtado, C. 2016, El Comercio, Gestión, párr. 1-6) 
Figura 1.5.

Línea de tiempo del Contrato de Concesión del Aeropuerto Internacional Jorge Chávez y modificaciones contractuales
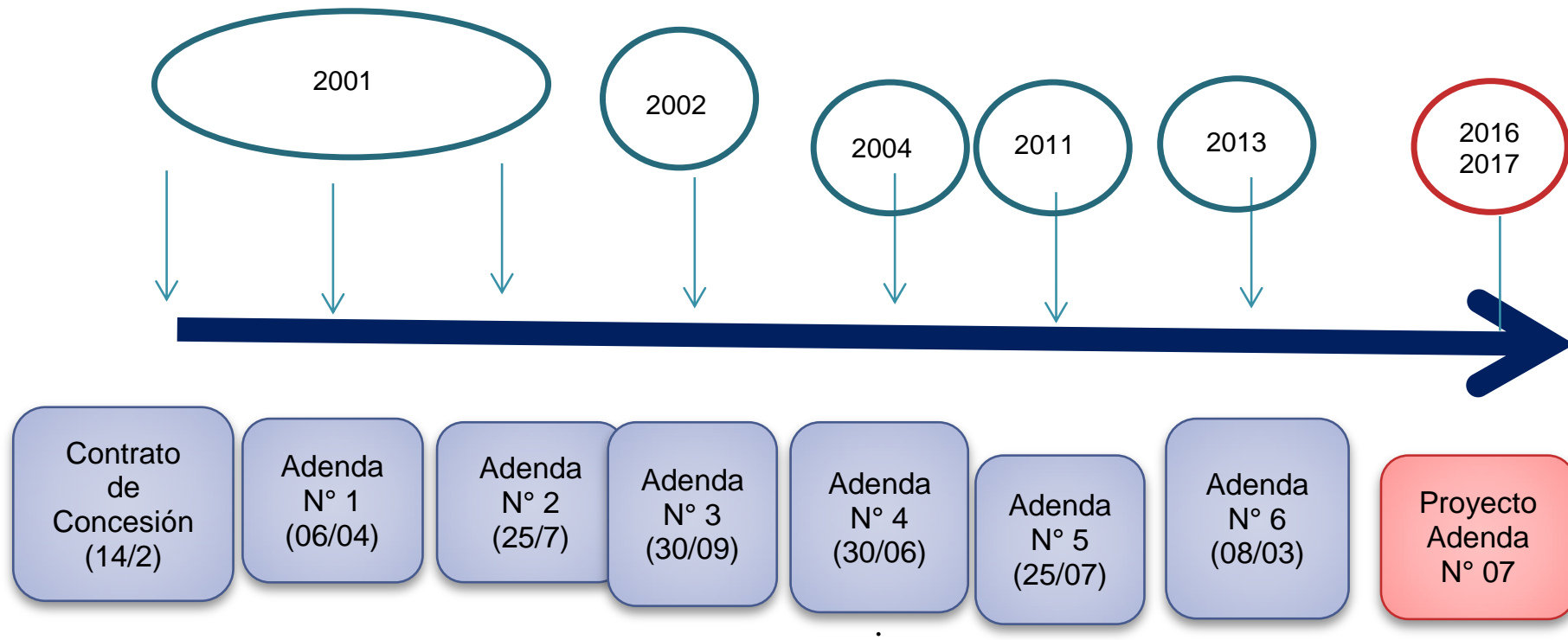

Proyecto
Adenda
$\mathrm{N}^{\circ} 07$

Fuente: RPP Noticias. Cuánto se invirtió en el Aeropuerto Jorge Chávez? (17 de febrero de 2017)

Tabla 1.7.

Principales conceptos de las modificaciones contractuales efectuadas con el Concesionario del Aeropuerto Jorge Chávez

\begin{tabular}{|c|c|}
\hline ADENDA & CONCEPTO \\
\hline Adenda $N^{\circ} 01$ & $\begin{array}{l}\text { - Modificación de la cláusula de solución de controversias (razones } \\
\text { no técnicas). } \\
\text { - Ampliación de las causales de modificación contractual } \\
\text { - Afectación del equilibrio económico financiero del contrato } \\
\text { (modificación porcentaje) }\end{array}$ \\
\hline Adenda $\mathrm{N}^{\circ} 02$ & $\begin{array}{l}\text { - Modificación acreedores permitidos. } \\
\text { - Modificación de garantías permitidos. }\end{array}$ \\
\hline Adenda $\mathrm{N}^{\circ} 03$ & - Modificación del concepto de ingresos brutos y procedimiento de \\
\hline
\end{tabular}




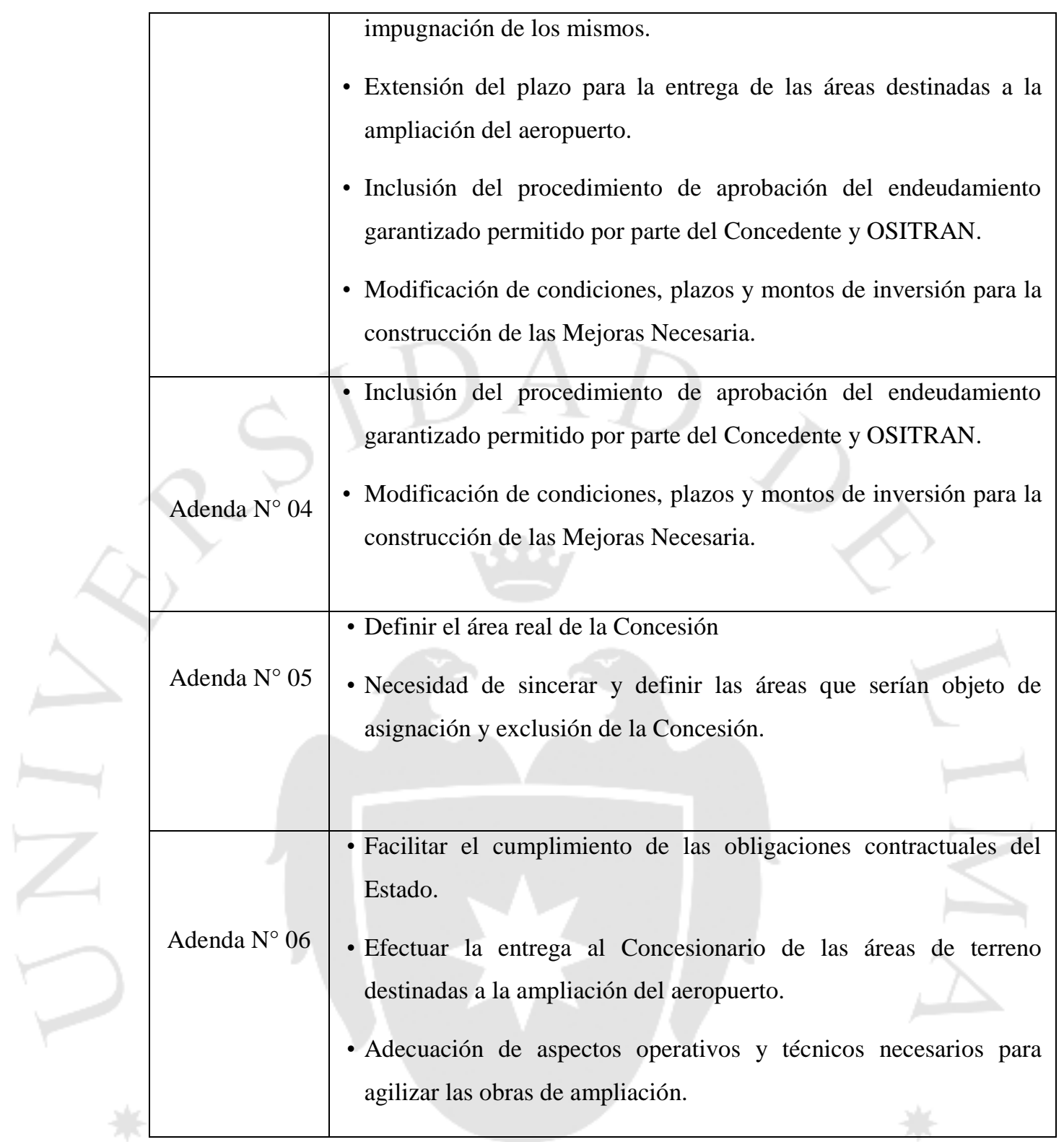

Fuente: Radio Programas del Perú Noticias. Cuánto se invirtió en el Aeropuerto Jorge Chávez? (17 de febrero de 2017)

Como observamos, la ineficiencia del Estado peruano en la entrega de los terrenos necesarios para la ampliación del aeropuerto, viene motivando sendas modificaciones contractuales y por ende obliga al Estado a pagar una compensación.

\section{Caso proyecto "Línea 2 y ramal Av. Faucett - Av. Gambetta de la red básica del} Metro de Lima y Callao": 
La Línea 2 del Metro de Lima está conformada por Av. Víctor Raúl Haya de la Torre (Carretera Central), Av. Nicolás Ayllón, Av. 28 de Julio, Av. Guzmán Blanco, Av. Arica, Av. Venezuela, Av. Germán Amézaga, Av. Oscar R. Benavides (Colonial) y Av. Guardia Chalaca. La construcción de la Línea 2 del Metro de Lima y Callao, a la fecha presenta un avance de sólo el $15.71 \%$, cuando -de acuerdo al cronograma- debería estar en un 41.85\%; precisar que en junio del 2016, los avances estaban al 9\%, es decir, solo se ejecutó 6\% en un año. En agosto del 2016 las obras debieron estar al 40\%, para poder concluirse en su totalidad hacia el 2021. Los retrasos responden a diversos problemas: a) Expropiación que debe realizarse en los predios todavía no cuenta con fecha ciertas ni acuerdos; b) la concesionaria y el MTC no llegan a ponerse de acuerdo dado que en el Perú no existe una norma sísmica de edificaciones para construcciones subterráneas; situación que ha conllevado que en plena ejecución de la línea 2, se decida continuar las obras con una norma sísmica extranjera, lo cual implica construir muros con más espesor y más material; por lo cual la Concesionaria ha exigido un monto mayor de dinero para compensar el acero y el concreto adicionales que se requerirán, requerimiento que el gobierno habría rechazado. El consenso entre ambas partes no tiene fecha; c) Temor frente al efecto Odebrecht. Si bien la línea 2 del metro no es un proyecto ejecutado por la investigada, la vinculación de este proyecto estaría con la línea 1, que sí fue encargada a esta firma brasileña; con lo cual para la Línea 2 existe temor en el ámbito político frente a cualquier firma de contrato o adenda; d) existen problemas operacionales; e) De los 108 estudios de ingeniería (EDI) que necesita el proyecto, se han aprobado menos de 30; y e) Las tuneladoras llegaron al Perú en marzo del 2016 y que debían comenzar a excavar los 35 kilómetros este año, aún no pueden operar. (León Almenara, J. P., 2017, El Comercio, párr. 3-10)

En general los motivos del retraso se deben nuevamente a factores de ineficiencia del estado peruano, principalmente porque no se cumplió con la entrega de los terrenos de la obra en el plazo, respondiendo a problema de expropiaciones, con lo cual se ha generado un perjuicio económico a la Concesionaria de aproximadamente US\$ 263 millones. Aunado a ello, se advierten problemas sociales: alto caos vehicular y problemas de negocios cerrados por la implementación y demora del proyecto. Siendo que a inicios de febrero del 2007, la empresa concesionaria de la Línea 2 del Metro de 
Lima, presentó a inicios de febrero de 2017 una demanda indemnizatoria contra el estado peruano ante el centro internacional de arreglo de Diferencias relativas a Inversiones (CIADI), para lo cual el Estado ha contratado un estudio Foley Hoag (Bostosn) para que lo defienda en el arbitraje; sin embargo, no se advierte acciones conciliatorias del Estado peruano en aras de no seguir sacrificando los beneficios esperados que tiene el proyecto para la ciudadanía pese a que el origen del conflicto se sustenta en su ineficiencia y falta de gestión.

\section{Caso Gasoducto Sur Peruano:}

El ingreso del gaseoducto no solo originará una considerable alza en las tarifas eléctricas sino que unido a otras intervenciones del Estado en el sector, están generando una serie de distorsiones y deficiencias en la asignación de recursos; los consumidores eléctricos tendremos que entregar más de 11,000 millones de dólares en subsidios por el Gasoducto Sur Peruano (GSP). (Gobierno debería renegociar contrato del Gasoducto al sur, 11 de agosto de 2016, Gestión, párr. 1-2).

El Gobierno resolvió terminar la concesión del Gasoducto Sur Peruano debido a que el consorcio no cumplió con demostrar que tiene el financiamiento necesario para la realización de la obra; dado que ese financiamiento tenía que ser obtenido de la comunidad financiera internacional. El consorcio a cargo del proyecto está formado por la brasileña Odebrecht, la española Enagás y la peruana Graña y Montero. La presencia de Odebrecht, que ha admitido haber pagado sobornos en varios países de América Latina, ha sido la causa por la cual las entidades financieras no quisieron prestar dinero al consorcio. (Gobierno pone fin a la Concesión del Gasoducto Sur Peruano, 23 de enero de 2017, El Comercio, párr. 1-5).

Dicha situación conlleva que al haberse dejado sin efecto la Concesión, el Estado peruano deba volver a concesionar el proyecto, teniendo cautela de no incurrir en las mismas falencias.

\section{Caso aeropuerto Chinchero del Cuzco:}


El proyecto fue concesionado en el 2014 al consorcio Kuntur Wasi, conformado por Andino Investmen Holding (AIH) y Corporación América, vía una asociación públicoprivada. Existe una controversia entre el Estado y la empresa concesionaria en relación a la tasa de interés que el Estado debe pagar por los US\$265 millones solicitados en el cofinanciamiento, según Alfonso Segura ex titular del MEF, el Estado había calculado una tasa alrededor del 9,5\% para pagarle al concesionario. La empresa asegura que, tal como estaba estipulado en el contrato, al Estado le correspondería pagar incalculables intereses durante el período de gracia (5años) lo cual asciende a 22.5\%; con lo cual se advierte que la modificación solicitada implicaría un traslado del riesgo de financiamiento del concesionario al Estado. Con ello, se genera controversia sobre lo que se conoce como una evaluación del valor por dinero; por cuanto si se da la modificación del contrato tal como se propone, el Estado estaría perdiendo el valor por dinero, con lo cual se pone en duda si realmente resultaba más eficiente la opción de APP en comparación a la ejecución vía obra pública. (Gálvez Córdova, V., 18 de enero 2017, El Comercio, párr. 2-27).

Finalmente el MTC suscribió la adenda con el Consorcio Kuntur Wasi, la cual fue cuestionada no solo por el Congreso sino también por parte de la Contraloría General, la cual emitió dos opiniones previas, que advertían los riesgos que podría generarse. Finalmente en el marco del control posterior la Contraloría General emitió Informe de control determinando presuntos indicios de delito así como inicio de procedimiento administrativo sancionador contra 10 funcionarios que participaron durante el proceso de suscripción de la adenda. Dicha situación ha motivado la renuncia del Ministro del MTC y serias reacciones del pueblo de Cusco que ven truncadas otra vez por ineficiencias del gobierno central sus sueños y beneficios de desarrollo que iba a otorgar el proyecto.

En los casos de coyuntura social expuestos, se advierte una muestra de la problemática que viene suscitándose en el Estado peruano desde la planificación de los proyectos, que como producto de renegociaciones no solo se han generado perjuicios económicos sino afectación a la institucionalidad de las APP y un pésimo mensaje a la inversión extranjera de problemas de corrupción y favorecimiento a concesionarios. 
Este aspecto será también ampliado en el capítulo II del presente trabajo de investigación.

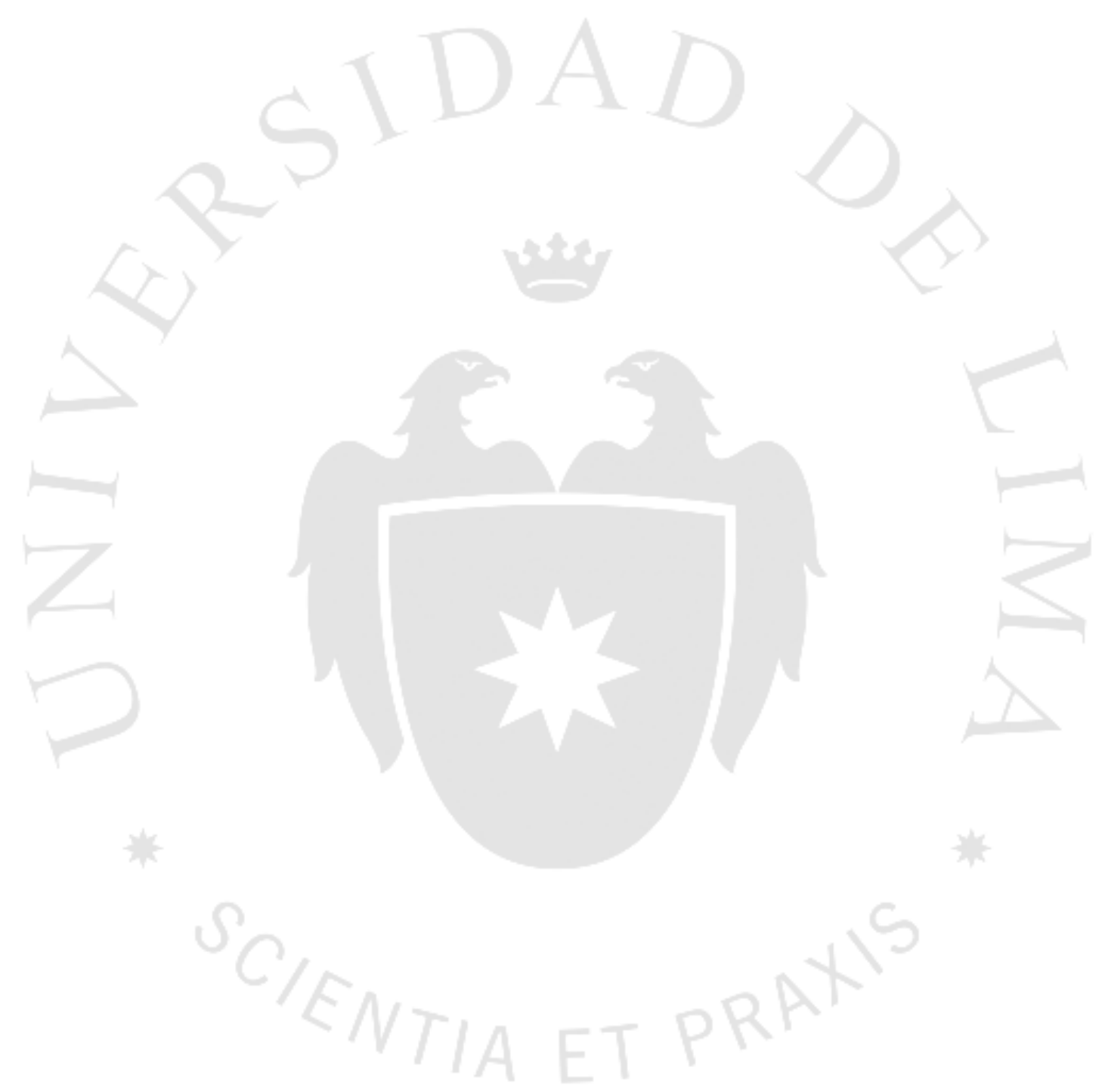




\section{CAPÍTULO II: ROL DE LA CONTRALORÍA GENERAL DE LA REPÚBLICA EN PROYECTOS DE INVERSIÓN A TRAVÉS DE APP}

Este segundo capítulo, en la línea de lo que hemos venido revisando en el capítulo anterior, busca enfatizar que sí es posible lograr eficacia del Estado en los proyectos de inversión mediante la implementación de APP, ello principalmente si vamos de la mano con un socio estratégico, que es la Contraloría General de la República - Entidad descentralizada de Derecho Público, constitucionalmente autónoma - permitiéndole contribuir desde un enfoque integral y preventivo orientado a una gestión por resultados. Para lo cual se analizará el rol de la Contraloría General de la República, sus diferentes formas de intervención pero apostando por el control previo como un facilitador en los procesos de promoción de la inversión pública. Asimismo, se tendrá en cuenta la normativa que ha emitido la Contraloría General en los últimos años respecto a la implementación de proyectos de inversión mediante APP buscando optimizar su labor de fiscalización; así como se tomará en cuenta las buenas prácticas internacionales en torno a lineamientos y directrices que existen en las Entidades Fiscalizadoras Superiores (EFS) o Contralorías Generales del mundo; los cuales constituyen una fuente de orientación, traslado de conocimientos y experiencias en la implementación de proyectos de APP en sus países; ello permitirá que las intervenciones de control se optimicen, de tal forma que permitan que el control gubernamental pueda generar valor en la mejora de la gestión de los proyectos de APP, así como mayor rentabilidad e impacto positivo en el bienestar del ciudadano.

\subsection{El Control Gubernamental y el rol de la Contraloría General de la República}

El control gubernamental, consiste en la supervisión, vigilancia y verificación de los actos y resultados de la gestión pública, en atención al grado de eficiencia, eficacia, transparencia y economía en el uso y destino de los recursos y bienes del Estado; así 
como del cumplimiento de las normas legales y de los lineamientos de política y planes de acción, evaluando los sistemas de administración, gerencia y control, con fines de su mejoramiento a través de la adopción de acciones preventivas y correctivas pertinentes. (Ley $\left.\mathrm{N}^{\circ} 27785,2002\right)$

Dicho control gubernamental es ejercido por la Contraloría General de la República (CGR), entidad descentralizada de Derecho Público, que goza constitucionalmente de autonomía acorde con su ley Orgánica; constituyéndose en el Órgano Superior del Sistema Nacional de Control $^{6}$, quien supervisa la legalidad de la ejecución del Presupuesto del Estado, de las operaciones de la deuda pública y de los actos de las Instituciones sujetas a control. (Constitución Política del Perú, 1993) (El subrayado es nuestro)

Esta labor del control gubernamental que ejerce la Contraloría General de la República (CGR) constituye un proceso integral y permanente, que tiene como finalidad contribuir a la mejora continua en la gestión de las entidades; así como el uso de los bienes y recursos del Estado. (Normas Generales de Control, 2014). Por lo que este Organismo Superior de Control, puede ejercer su labor de manera transversal e independiente a diferencia de cualquier Entidad Pública, pudiendo fiscalizar simultáneamente en diversas entidades de distintos sectores y niveles de gobierno con autonomía.

Esta situación, permite, como se verá más adelante, no solo determinar responsabilidades frente a incumplimientos administrativos funcionales sino también constituirse como una orientación preventiva que busca alertar al Titular de la entidad en aras de que pueda evaluar y sustente la decisión que implemente su sector. Las entidades sujetas al sistema Nacional de Control, tenemos:

Tabla 2.1.

Entidades sujetas al control gubernamental de CGR

6 Estableciéndose como Sistema Nacional de Control al conjunto de Órganos de Control, normas, métodos y procedimientos, estructurados e integrados funcionalmente, destinados a conducir y desarrollar el ejercicio del control gubernamental en forma descentralizada 


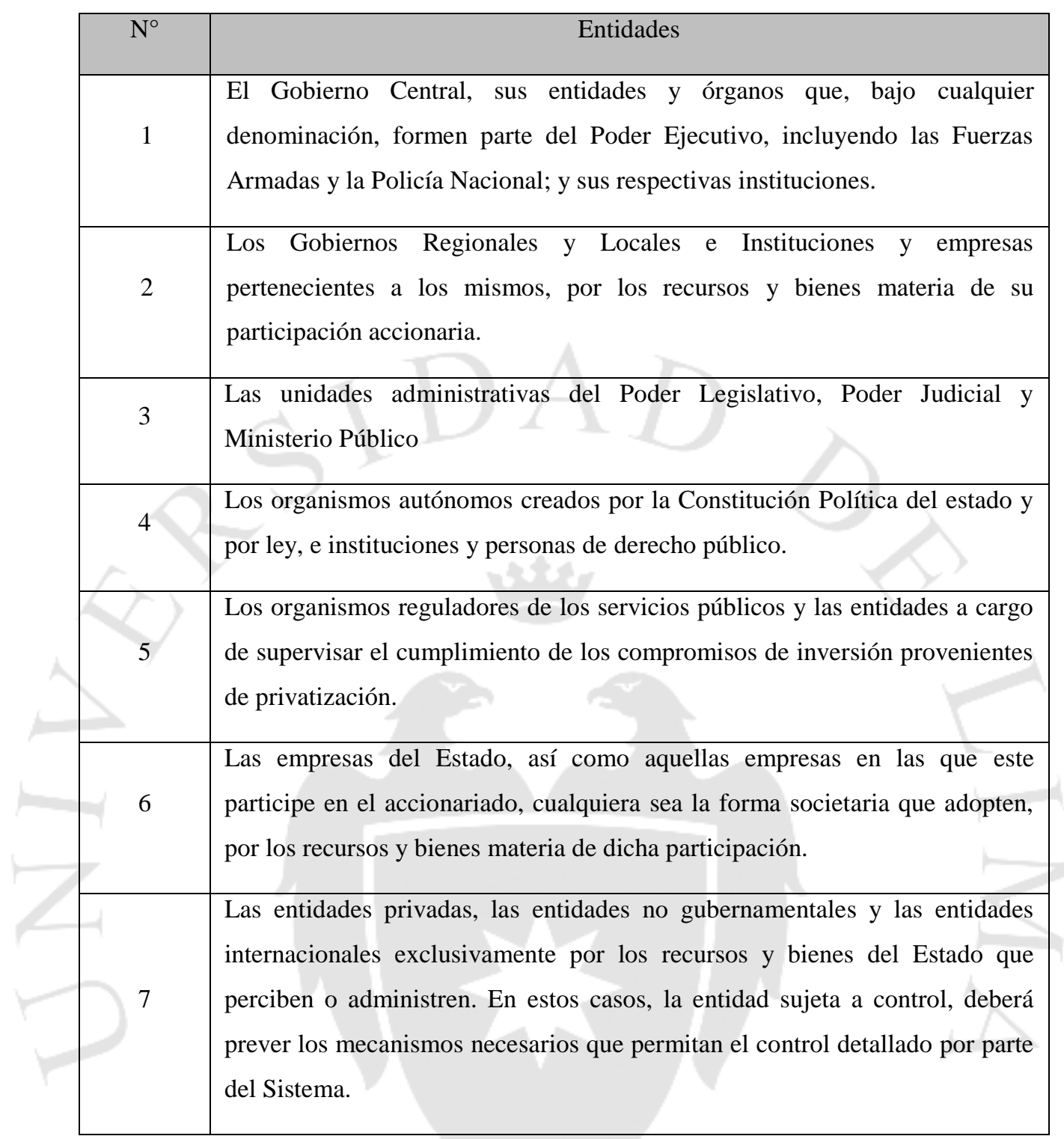

Fuente: $\quad$ Ley $\mathrm{N}^{\circ} 27785$ - Ley Orgánica del Sistema Nacional de Control y de la Contraloría General de la República y Normas Generales de Control Gubernamental.

Es importante tener en cuenta, que el control gubernamental, se clasifica de la siguiente manera:

- En función de quien lo ejerce: control interno y externo.

- En función al momento de su ejercicio: control previo, simultáneo y posterior. (Normas Generales de Control, 2014)

Estableciéndose que el ejercicio del control gubernamental impone obligaciones funcionales a quienes lo efectúan. Esta labor se realiza principalmente a través de servicios de control por los Órganos del Sistema, conformado por: i) La Contraloría 
General de la República, como ente rector del sistema; ii) los Órganos de Control Institucional de las entidades sujetas a control; y iii) Las Sociedades de Auditoría Externa independientes, cuando son designadas por la CGR y por un período determinado.

Es así que dentro de los tipos de servicio de control, como se ha señalado tenemos: el control previo, simultáneo y posterior que son prestados por la CGR y los Órganos del Sistema Nacional de Control, conforme a sus competencias legales y funciones descentralizadas; pudiendo incluso el servicio de control posterior ser ejercido por las Sociedades de Auditoría cuando son designadas y contratadas conforme a la normativa sobre la materia. Lo comentado se detalla a continuación:

Tabla 2.2.

Tipos de servicios de control gubernamental

\begin{tabular}{|c|c|c|}
\hline $\begin{array}{c}\text { Servicio de } \\
\text { control }\end{array}$ & Concepto & Modalidades \\
\hline Previo & $\begin{array}{l}\text { Son aquellos que } \\
\text { efectúa exclusivamente } \\
\text { la CGR }\end{array}$ & $\begin{array}{l}\text { - Autorizar presupuestos adicionales de } \\
\text { obra y mayores servicios de } \\
\text { supervisión. } \\
\text { - Informar sobre las operaciones que en } \\
\text { cualquier forma comprometan el crédito } \\
\text { o capacidad financiera del Estado. } \\
\text { - Opinar sobre las contrataciones con } \\
\text { carácter de secreto militar o de orden } \\
\text { interno } \\
\text { Otros establecidos por normativa } \\
\text { expresa }\end{array}$ \\
\hline Simultáneo & 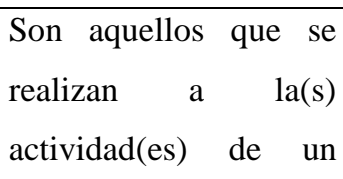 & $\begin{array}{l}\text { - Acción Simultánea: Evalúa el } \\
\text { desarrollo de una o más actividades en } \\
\text { ejecución de un proceso en curso, }\end{array}$ \\
\hline
\end{tabular}




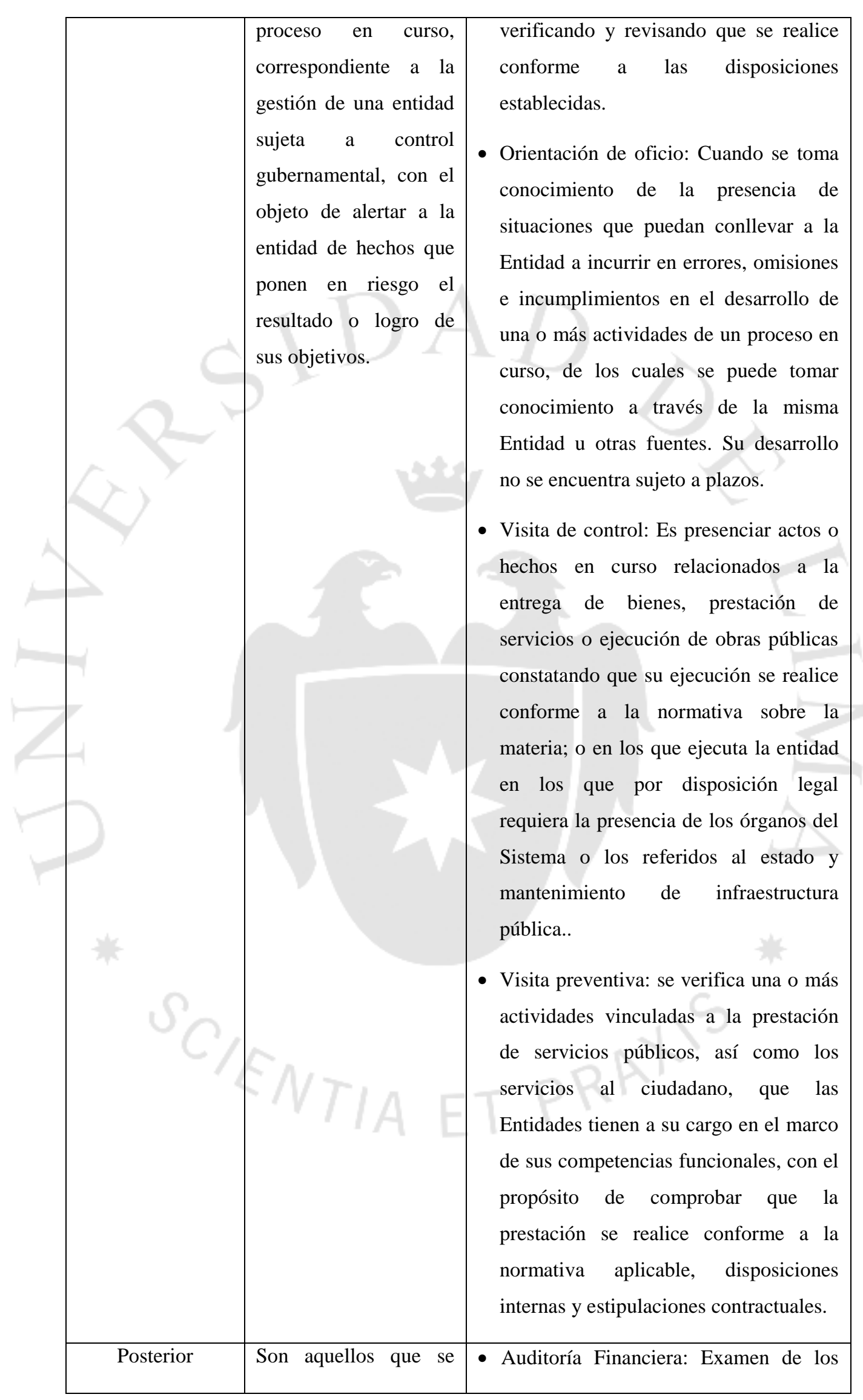




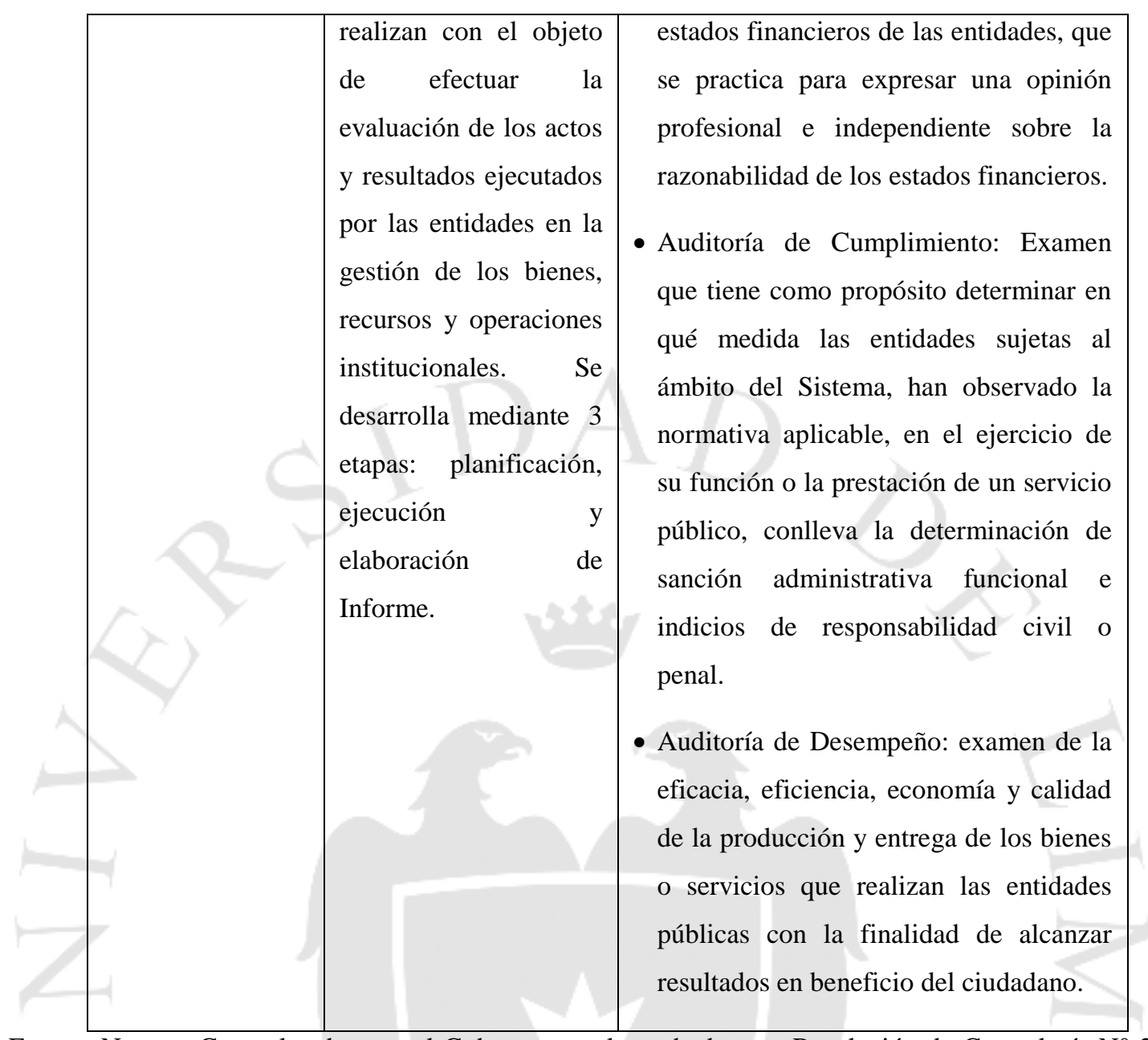

Fuente: Normas Generales de control Gubernamental aprobadas por Resolución de Contraloría $\mathrm{N}^{\circ} 273$ 2014-CG; y Directiva n. ${ }^{\circ}$ o17-2016-CG/DPROCAL aprobada por Resolución de Contraloría n. ${ }^{\circ}$ 4322016-CG.

Como advertimos, el control gubernamental, constituye una herramienta efectiva para la gestión pública; y a su vez, el rol que ejerce la CGR resulta fundamental, debiendo ser visto como un socio estratégico para que el Estado logre sus objetivos con el resultado e impacto esperado en el ciudadano; sin embargo, hay que tener en cuenta que constituye una labor dinámica y técnica, que debe ser continuamente mejorada según los cambios y riesgos que la Entidad enfrente y no solo segmentarse a una evaluación de cumplimiento normativo; así como el personal auditor debe estar en constantes capacitaciones, con el objeto de asegurar que lo que se recomiende en los Informes de 
Control producto del cierre del servicio de control ${ }^{7}$ estén de acuerdo con los objetivos de política nacional, entorno, y resultados esperados por el sector.

\subsubsection{El Control previo como un facilitador en los procesos de promoción de la inversión pública.}

Al respecto, para este trabajo de investigación se ha considerado importante solo abordar el control previo, entendido como una atribución que efectúa exclusivamente la Contraloría General de La República (CGR) con anterioridad a la ejecución de un acto u operación de una Entidad, de acuerdo a lo establecido por norma legal, a fin de emitir un resultado de acuerdo a la materia del requerimiento que realice la entidad solicitante. Al respecto, podemos advertir dos modalidades en las cuáles aplica el control previo, al: a) Otorgar autorización previa respecto de la ejecución y pago de los presupuestos adicionales de obra pública (PAO), y de las mayores prestaciones de supervisión de Obra (PAS) en los casos previstos en la normativa de la materia; y b) Informar previamente de las operaciones que comprometan el crédito o capacidad financiera del Estado sea que se trate de negociaciones en el país o en el exterior. (Contraloría General de la República, 2016)

Es en ese entendido que la Contraloría general de la República de acuerdo a su Ley Orgánica del Sistema Nacional de Control y de la Contraloría general de la República, en adelante Ley Orgánica, ejerce control previo de las operaciones, fianzas, avales y otras garantías que otorgue el Estado, inclusive los proyectos de contrato, que en cualquier forma comprometa su crédito o capacidad financiera, sea que se trate de negociaciones en el país o en el exterior" (Ley N²7785, 2002)

Como resultado de la labor, se emite un Informe previo que constituye un documento técnico, resultado del proceso de verificación y análisis de la documentación sustentatoria presentada por la Entidad y adecuada al marco aplicable a las operaciones materia del informe; no constituye en sí mismo una autorización o aprobación de la operación; así como no exceptúa el ejercicio del control posterior de la operación materia

\footnotetext{
7 Los servicios de control constituyen el conjunto de procesos cuyos productos tienen el propósito dar una respuesta satisfactoria a las necesidades de control gubernamental que corresponde atender a los Órganos del sistema.
} 
de Informe ni el ejercicio de control simultáneo cuando dicha operación se encuentre en curso. Siendo que el plazo estipulado para pronunciarse en de 15 días hábiles de no haberse requerido documentación complementaria u adicional y 05 días hábiles adicionales si se requirió documentación adicional. (Resolución de Contraloría $\mathrm{N}^{\circ} 148$ 2016-CG, 2016)

\section{Tabla 2.3.}

Cuándo se debe presentar la solicitud para la emisión de un Informe previo?

Se deberá presentar previo a que se concreten las siguientes situaciones ${ }^{8}$ :

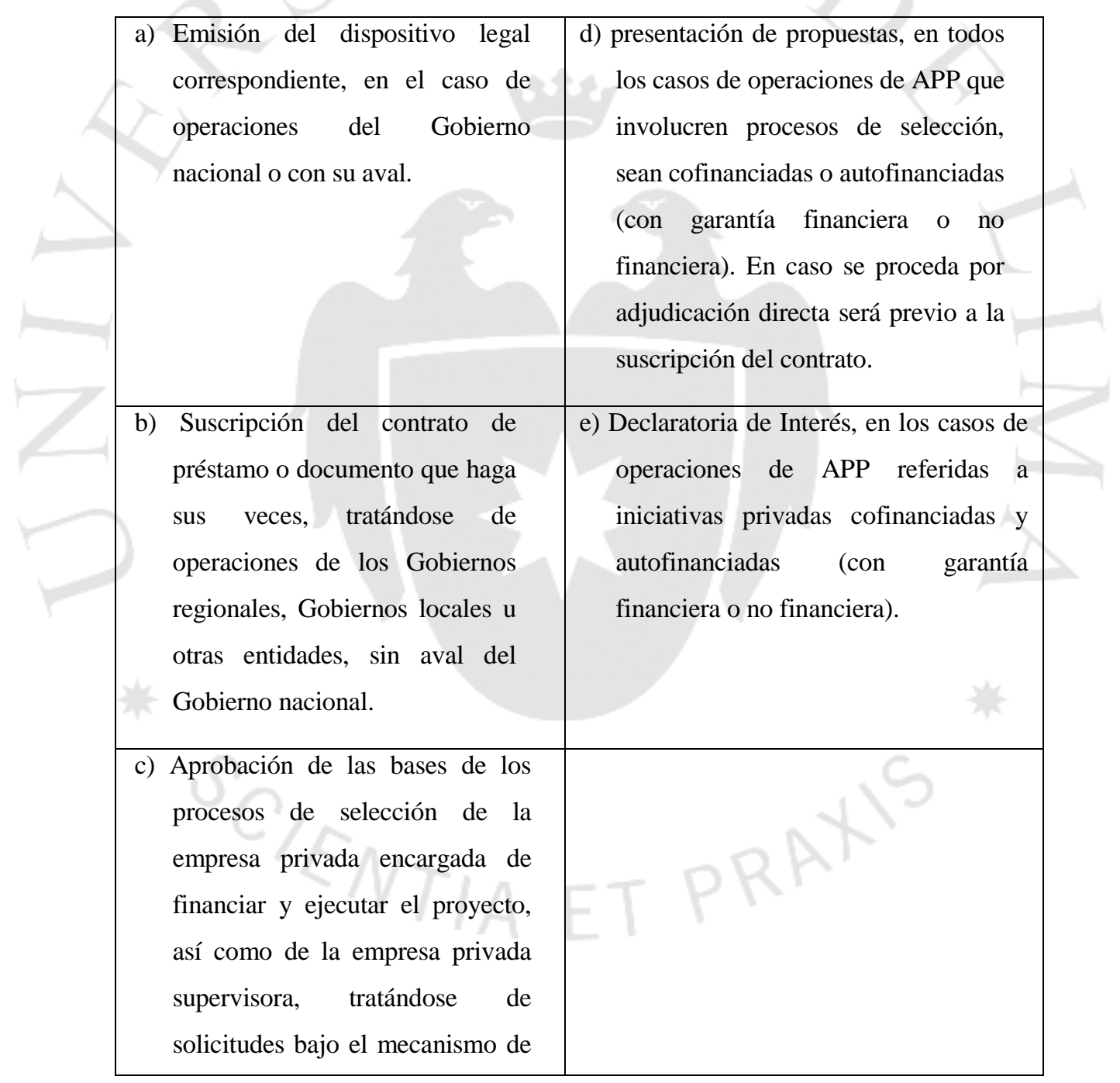

8 Es responsabilidad del Titular de la Entidad solicitar la emisión del Informe previo para las operaciones ya señaladas; el incumplimiento de la presente disposición constituye infracción sujeta a la potestad sancionadora (RIS) de la Contraloría General prevista en el literal g) del artículo 42 de la Ley $\mathrm{N}^{\circ} 27785$, sin perjuicio de la responsabilidad, civil o penal que corresponda. 
Fuente: Resolución de Contraloría N. ${ }^{\circ}$ 148-2016-CG de 13 de mayo de 2016 que aprueba la Directiva $n .^{\circ}$ 012-2016-CG/CPROD “Emisión de Informe previo establecido por el literal 1) del artículo $22^{\circ}$ de la Ley $\mathrm{N}^{\circ} 27785^{\prime}$.

Importante concluir, que la intervención que realiza la Contraloría General para que pueda ser control previo, exige que sea con anterioridad a la ejecución de un acto u operación de una Entidad, y siempre y cuando se trate de operaciones que comprometan el crédito o la capacidad financiera del Estado peruano; caso contrario no procede emitir Informe de control previo.

\subsection{Normas que regulan la intervención de la Contraloría General de la República en el proceso de promoción de la inversión privada}

Al respecto, el inciso 1) del Art. $22^{\circ}$ de la Ley Orgánica, señala como atribución de la CGR el informar previamente sobre las operaciones, fianzas, avales y otras garantías que otorgue el Estado, inclusive los proyectos de contrato, que en cualquier forma comprometa su crédito o capacidad financiera, sea que se trate de negociaciones en el país o en el exterior. (Ley $\left.N^{\circ} 27785,2002\right)$ (El Subrayado es nuestro)

Aunado a ello, la Contraloría General de la República ha definido qué debe entenderse por "operaciones que comprometan el crédito o la capacidad financiera" como aquellas operaciones financieras o no financieras que derivan en el incremento del stock y el servicio de deuda pública o generan pasivos o compromisos firmes o contingentes para el Estado, según sea el caso. (Resolución de Contraloría $\mathrm{N}^{\circ}{ }_{148 \text { - }}$ 2016-CG, 2016)

Concordante con ello, en la normativa de APP se precisa que el Informe Previo de la Contraloría General de la República respecto de la versión final del contrato de Asociaciones Público Privadas únicamente puede referirse a aquellos aspectos que comprometan el crédito o la capacidad financiera del Estado, de conformidad con el inciso i) del artículo 22 de la Ley $\mathrm{N}^{\circ}$ 27785, Ley Orgánica del Sistema Nacional de Control y de la Contraloría General de la República. Dicho Informe Previo no es vinculante sin perjuicio del control posterior. (Decreto Legislativo N. ${ }^{\circ} 1251,2016$ ) 
Es importante entender, que las opiniones que se otorgan en el marco del control previo, se dan con anterioridad a la ejecución de un acto u operación y se encuentran en la esfera preventiva, donde lo que se busca es alertar a través de la emisión del Informe Previo al Titular de la Entidad (Concedente) en torno a la versión final del contrato previo a la adjudicación; no se busca determinar responsabilidad frente a errores, omisiones o incumplimientos que se puedan advertir, como resultado de la opinión previa otorgada; por lo tanto, no constituye en sí mismo una autorización o aprobación de la operación. Caso contrario, restringiría la posibilidad de una revisión más exhaustiva a través del control posterior; aquí los auditores - frente a hechos concluidos - buscarán determinar en donde, en qué o quiénes estuvo la causa que conllevó el perjuicio económico al Estado o grave afectación al servicio público como producto de la implementación de APP en proyectos de inversión, buscando determinar responsabilidades administrativas funcionales, civiles o penales

Adicionalmente, como parte del control simultáneo se ha aprobado regular la actuación de los grupos de control de inversiones ${ }^{9}$ a cargo de la Contraloría General de la República, con el propósito de fortalecer el control efectivo, oportuno y adecuado en el uso y gestión de los recursos y bienes del Estado en los proyectos o programas de inversión de las entidades sujetas al ámbito del Sistema Nacional de Control. (Resolución de Contraloría N³89-2016-CG, 2016)

En igual sentido, se ha emitido una guía de Auditoría de Cumplimiento a las asociaciones Público Privadas, que es un control posterior de cumplimiento de legalidad, que busca orientar el desarrollo de las auditorías de cumplimiento mediante la revisión y evaluación de los procesos que se llevan a cabo para la implementación de una APP; con lo cual no se limita sino complementa los procedimientos de auditoría que apliquen en el marco de una auditorías de cumplimiento a una APP; y que para efecto de ello, el "macro proceso de implementación de una APP" fue divido en 04 procesos: a) De sección del proyecto; b) De promoción; c) De ejecución pre operativa; y, d) De operación. (Guía de Auditoría de Cumplimiento a las APP, 2015)

\footnotetext{
9 Es el equipo técnico conformado por profesionales especializados en control gubernamental, acreditados en la entidad o entidades a cargo del proyecto o programa de inversión, responsable del seguimiento a su ejecución,, realiza en coordinación con la unidad orgánica de la cual depende, los servicios de control que correspondan.
} 
Esta guía es de uso interno para la CGR y los Órganos de Control Institucional que tienen bajo su ámbito entidades que participan en el proceso de implementación de una APP; sin embargo, dicho documento contribuye a complementar los procedimientos de auditoría que se aplicarán en el marco de la auditoría de cumplimiento.

Por lo expuesto, advertimos que la intervención de la Contraloría General de la República, se da no solo a nivel de control previo en caso de operaciones que comprometan el crédito o la capacidad financiera del Estado sino también a través del control simultáneo y control posterior, mediante principalmente auditorías de cumplimiento; sin embargo, hoy por hoy han venido generándose alertas en torno a las "renegociaciones" en contratos de proyectos de APP que han venido conllevando pérdidas económicas importantes al Estado y que de acuerdo a estudios que se han venido realizando, se motivaron en hechos que pudieron ser previsibles desde el planeamiento y programación del proyecto. Este aspecto se analizará en el capítulo III del presente Trabajo de investigación.

\subsubsection{Algunas alertas de normativa de carácter internacional}

La Organización Internacional de Entidades Fiscalizadoras Superiores - INTOSAI es un organismo autónomo, independiente y apolítico. Al ser una organización no gubernamental con un estatus especial con el Consejo Económico y Social de las Naciones Unidas (ECOSOC), cuenta con 192 Entidades Fiscalizadoras Superiores (EFS) o Contralorías Generales a nivel mundial como miembros de pleno derecho y 5 miembros asociados; recogiendo las mejores prácticas aplicables sobre auditoría gubernamental de diversas EFS con la finalidad de mejorar los procesos, técnicas de las mismas y superar falencias, así como compartir los conocimientos entre las EFS miembros. (INTOSAI, 2017)

En el caso específico de las auditorías a la implementación de proyecto a través de APP, se tiene entre las principales normas Internacionales de las Entidades Fiscalizadoras Superiores - ISSAI, las siguientes: 
- ISSAI 5220 "Lineamientos para la mejor práctica en la Auditoría de Financiamiento Público/ Privado y Concesiones", estos lineamientos tienen como objetivo orientar a las EFS que vayan a auditar una APP buscando evaluar si el sector público ha obtenido el mejor acuerdo posible (valor público) para el ciudadano; y será aplicable teniendo en cuenta el grado de madurez de cada APP en cada país.(INTOSAI, 2007)

Se advirtió que este enfoque de prestación de servicios puede ofrecer la perspectiva de una mejor relación calidad - precio que los métodos tradicionales de financiamiento público, lo cual requiere de nuevas habilidades por parte del sector público. Estos lineamientos se encuentran divididos en 6 secciones que se detallan a continuación:

Tabla 2.4 .

Lineamientos internacionales para la mejor práctica en la auditoría de una APP

\begin{tabular}{|c|c|c|}
\hline ISSAI 5220 & Directrices & Comprende \\
\hline $\begin{array}{c}\text { Sección } 1 \text { - } \\
\text { "El enfoque general de la } \\
\text { EFS" }\end{array}$ & $\begin{array}{l}\text { 1. Responsabilidad de la EFS } \\
\text { 2. Adquisición de las } \\
\text { habilidades necesarias. } \\
\text { 3. Participación de la EFS. } \\
\text { 4. Planificación de la } \\
\text { Auditoría. }\end{array}$ & $\begin{array}{l}\text { Si quiere realizar auditorías } \\
\text { de gestión bien concebidas, } \\
\text { necesita determinar sus } \\
\text { competencias para examinar } \\
\text { los contratos de } \\
\text { financiamiento, planificar } \\
\text { sus auditorías y evaluar } \\
\text { habilidades especializadas. }\end{array}$ \\
\hline $\begin{array}{l}\text { Sección } 2 \text { - "Definición del } \\
\text { alcance del proyecto" }\end{array}$ & $\begin{array}{l}\text { 5. Selección del proyecto } \\
\text { 6. Definición de los } \\
\text { requisitos del proyecto. } \\
\text { 7. Capacidades del sector } \\
\text { privado. } \\
\text { 8. Evaluación de beneficios } \\
\text { potenciales. } \\
\text { 9. Objetivos de política más } \\
\text { amplios } \\
\text { 10. Selección de la forma } \\
\text { más conveniente de } \\
\text { asociación. } \\
\text { 11. Innovación. } \\
\text { 12. Evaluación del riesgo. } \\
\text { 13. Capacidad dinanciamiento } \\
\text { potencial relación }\end{array}$ & $\begin{array}{l}\text { Se busca evaluar cómo se } \\
\text { decidió el alcance, la EFS } \\
\text { deberá entender cómo la } \\
\text { organización eligió este } \\
\text { proyecto antes que otros } \\
\text { posibles usos de sus recursos } \\
\text { y cuáles fueron sus objetivos } \\
\text { al decidirlo. Asimismo, } \\
\text { cómo estructuró el proyecto } \\
\text { para satisfacer sus } \\
\text { necesidades y el rol de las } \\
\text { capacidades del sector } \\
\text { privado. }\end{array}$ \\
\hline
\end{tabular}




\begin{tabular}{|c|c|c|}
\hline & $\begin{array}{l}\text { calidad - precio. } \\
\text { 14. Perfil del estudio de caso }\end{array}$ & \\
\hline $\begin{array}{c}\text { Sección } 3 \text { - "Gestión del } \\
\text { Proyecto". }\end{array}$ & $\begin{array}{l}\text { 15. Equipo de proyecto. } \\
\text { 16. Estudio de mercado. } \\
\text { 17. Temas contractuales } \\
\text { 18. Estrategia de licitación. } \\
\text { 19. Calendario del proyecto } \\
\text { 20. Comparación de costes y } \\
\text { beneficios } \\
\text { 21. Lista de ofertas } \\
\text { 22. Especificación de los } \\
\text { requisitos } \\
\text { 23. Mantenimiento de la } \\
\text { competencia } \\
\text { 24. Revisiones regulares } \\
\text { 25. Presupuesto para los } \\
\text { costes del proyecto } \\
\text { 26. Designación } \\
\text { consultores. de } \\
\text { 27. Administración de } \\
\text { costes. }\end{array}$ & $\begin{array}{l}\text { Cubre la evaluación de la } \\
\text { EFS acerca de la manera } \\
\text { cómo gestiona el proceso de } \\
\text { otorgamiento de un contrato; } \\
\text { evaluará si la organización } \\
\text { contó con un equipo con } \\
\text { experiencia y habilidades } \\
\text { necesarias, con } \\
\text { responsabilidad; asimismo si } \\
\text { hubo un correcto sistema de } \\
\text { control de costes. }\end{array}$ \\
\hline Sección 4 - "Licitación" & $\begin{array}{l}\text { 28. Propuestas del oferente. } \\
\text { 29. Evaluación del oferente. } \\
\text { 30. Elección del oferente. }\end{array}$ & $\begin{array}{l}\text { Es evaluar cómo una } \\
\text { organización seleccionó un } \\
\text { socio del sector privado y } \\
\text { luego negoció el contrato } \\
\text { final con él, se necesita } \\
\text { examinar si la organización } \\
\text { ha evaluado bien todas las } \\
\text { ofertas recibidas, la } \\
\text { asignación de riesgos, el } \\
\text { precio establecido y luego el } \\
\text { oferente preferido al ofrecer } \\
\text { el mejor valor. }\end{array}$ \\
\hline $\begin{array}{c}\text { Sección } 5- \\
\text { "El contrato adecuado" }\end{array}$ & $\begin{array}{l}\text { 31. Cambios durante las } \\
\text { negociaciones con el } \\
\text { oferente seleccionado. } \\
\text { 32. Logro de los objetivos. } \\
\text { 33. Evaluación } \\
\text { alternativas. } \\
\text { 34. Asegurar la prestación } \\
\text { del servicio. } \\
\text { 35. Confirmación de la } \\
\text { capacidad } \\
\text { financiación. }\end{array}$ & $\begin{array}{l}\text { Se cubre la evaluación de la } \\
\text { EFS acerca de la manera } \\
\text { como una organización antes } \\
\text { de comprometerse mediante } \\
\text { la firma del contrato, revisó } \\
\text { que el acuerdo era el } \\
\text { adecuado, así como las } \\
\text { negociaciones que se } \\
\text { hicieron para identificar los } \\
\text { efectos que causaron los } \\
\text { cambios acordados; } \\
\text { asimismo, se comprobará } \\
\text { que el acuerdo cumpliese } \\
\text { con los objetivos. }\end{array}$ \\
\hline
\end{tabular}




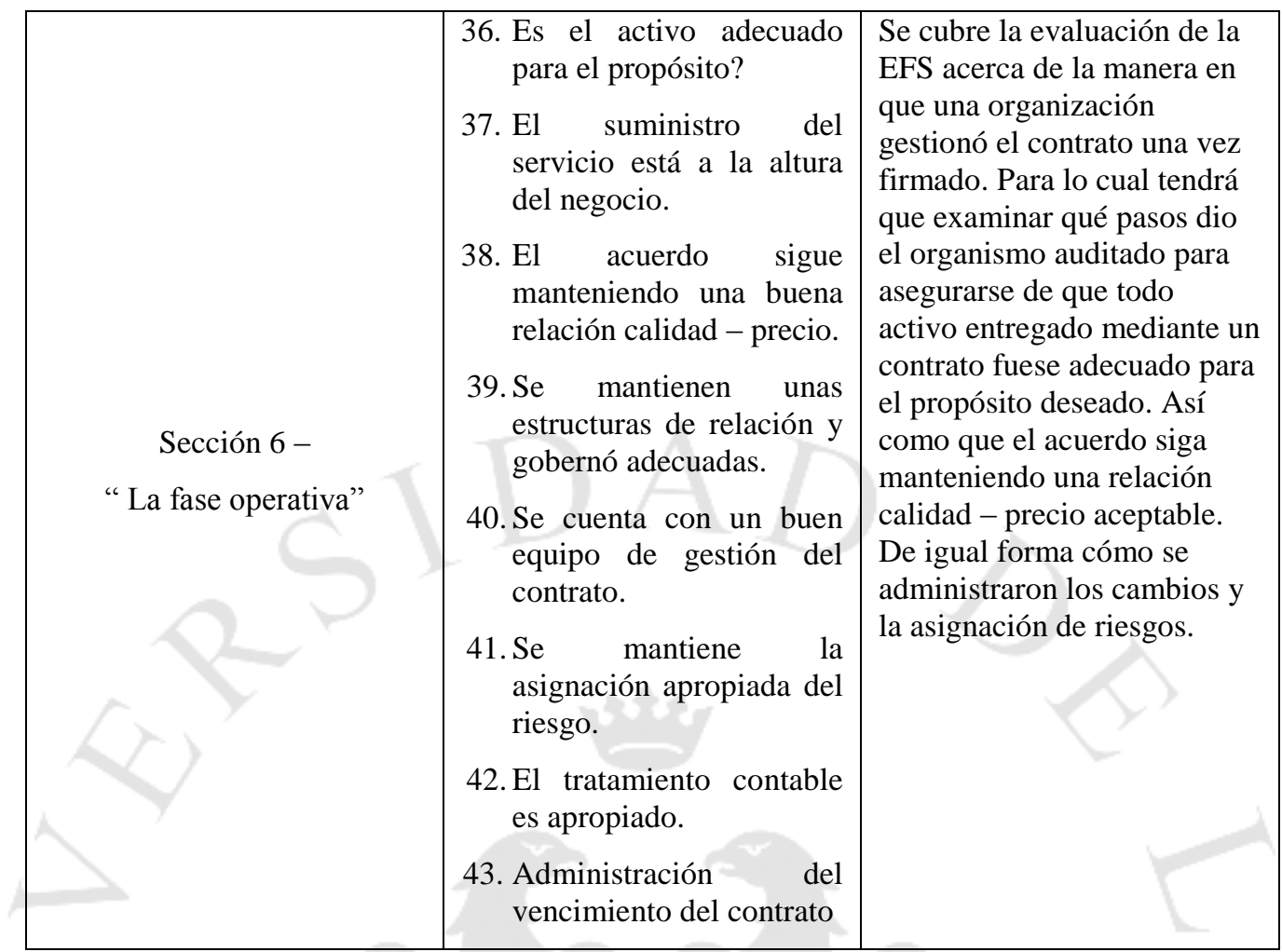

Fuente: ISSAI 5220 "Lineamientos para la mejor práctica en la Auditoría de Financiamiento Público/ Privado y Concesiones", emitida por la INTOSAI.

- ISSAI 5240 "Directrices sobre las mejores prácticas para la auditoría del riesgo en los Partenariados Público/ Privado (PPP)"

Aquí "partenariado" es el término que se utiliza para referirse a APP. Estas Directrices identifican riesgos claves, no es una metodología de auditoría propiamente dicha, son directrices que han sido estructuradas en dos partes. La primera de ellas relacionada con los "Riesgos a los que hace frente el Estado" a fin de lograr beneficios para la sociedad; y la segunda parte, precisa "los riesgos a los que hace frente las EFS" al realizar la auditorías a las APP; y a su vez, involucra un examen del proceso y de los resultados, identificando lecciones que merezcan la pena y seguimiento a las EFS a su propio trabajo. (INTOSAI, 2004)

Los lineamientos ponen de relieve riesgos importantes en la auditoría de los PPP que pueden surgir tanto desde el punto de vista del sector público como de la EFS. Se presentan al respecto recomendaciones de cómo enfrentar estos riesgos de la mejor forma posible. Los lineamientos presentan 
además experiencias de las EFS que forman parte del Grupo del Trabajo; sin embargo, no se busca que estas Directrices hagan frente a cada entorno de cambios que vivimos pero sin embargo constituye un beneficio de orientación práctica para las EFS. (INTOSAI, 2004)

Como podemos evidenciar, las normas internacionales a nivel de EFS nos otorgan pautas de orientación en función a las buenas prácticas y experiencias ya ganadas. Ello contribuye a generar conectividad y traslada el conocimiento en busca mejores auditorías. Lo cual permitirá que el control gubernamental pueda generar valor en la mejora de la gestión de los proyectos de APP, mayor rentabilidad e impacto positivo en el bienestar del nivel de vida del ciudadano. 


\section{CAPÍTULO III: PROPUESTA NORMATIVA DE PARTICIPACIÓN DE LA CONTRALORÍA GENERAL DE LA REPÚBLICA A TRAVÉS DEL CONTROL PREVIO EN LAS MODIFICACIONES CONTRACTUALES EN LOS PROYECTOS APP}

Este capítulo quiere dar a conocer una propuesta de solución frente a la problemática de falta de eficacia en la ejecución de los proyectos de inversión mediante APP. Es por ello, que se busca otorgar una propuesta normativa en donde se considerada vital "fortalecer el control previo que ejerce la Contraloría General de la República en el marco del Sistema Nacional de la Promoción de la Inversión Privada” dado que existe la necesidad de disponer de una herramienta de control previo que nos permita detectar de manera oportuna los posibles riesgos que involucren las modificaciones que se deriven de la adenda de los contratos de APP. Esta detección no es el fin en sí mismo, lo que se quiere lograr como resultado final de la intervención de la CGR es que la administración pública pueda adoptar oportunamente medidas preventivas o implementar medidas correctivas en salvaguarda de los intereses del Estado, con lo cual no solo se beneficiarán los intereses del estado sino también contribuirá así a garantizar la confianza de los inversionistas y de la ciudadanía en general; para lo cual se adoptó un caso práctico real del Aeropuerto de Chinchero en donde la participación técnica de la CGR desde un enfoque de control previo fue importante para el alertar al Poder Ejecutivo de hechos irregulares.

3.1 Problemas en la conclusión de proyectos de inversión por renegociaciones contractuales producto de la implementación del modelo de APP o por una mala gestión? 
Hoy por hoy, advierte la Contraloría General de la República (CGR, 2015) que si bien la participación del sector privado en las APP tiene la particularidad de evitar o reducir la exposición de los limitados recursos fiscales, trasladando al privado el costo total o parcial de la provisión del servicio de infraestructura y sus riesgos; los diferentes estudios han señalado que en determinados casos ello no ha venido ocurriendo. En la experiencia peruana, ha sido un hecho recurrente que gran parte de los contratos de concesión celebrados bajo la modalidad de APP han sufrido "renegociaciones", las cuales han modificado las condiciones bajo las cuáles esas concesiones fueron adjudicadas, generando efectos sobre las obligaciones, contraídas por las partes, los montos de inversión y los plazos de ejecución del proyecto. (p. 12)

Es en ese contexto, que en estudio recientemente realizado, la CGR (2015) evidenció problemas en la implementación:

Siendo uno de los más importantes, la alta incidencia de renegociaciones de los contratos al poco tiempo de ser adjudicados; así como deficiencias de los estudios técnicos y financieros de los proyectos que fueron previsibles desde el diseño del contrato; así como problemas por incumplimiento del plazo como de las obligaciones del estado (concedente) del saneamiento legal de terrenos. Si bien es cierto en algunos casos las adendas firmadas son justificables por la aparición de variables exógenas no previstas, también es cierto que en muchos casos se debe al incumplimiento de las obligaciones contractuales de las partes y principalmente del Estado peruano, lo cual reduce la eficiencia de los proyectos y por ende el bienestar social que estos deben generar. (pp. $11-18$ )

Es frente a esta problemática, que nuestra normativa sobre APP ha venido regulando y estableciendo candados institucionales al tema de las "modificaciones contractuales" (adendas) pese a que es una potestad válida entre las partes, máxime si se trata de contratos a largo plazo. Ello siempre y cuando se mantenga el equilibrio económico financiero y las condiciones de competencia del proceso de promoción, no debiendo alterar las adendas la asignación de riesgos y la naturaleza del proyecto.

Hoy por hoy, y como se ha señalado en el capítulo I del presente trabajo de investigación, la normativa de APP habla de “... procurando no alterar la asignación de riesgos y la naturaleza del proyecto". (Decreto Supremo Nº68-2017-EF, 2017); 
redacción normativa que resulta subjetiva e interpretativa, ya que tanto el Concedente como el Concesionario podrían interpretar que si ello se da, sería permisible legalmente pudiendo generar distorsiones en la implementación de proyectos mediante APP. Aunado a ello, respecto a la temporalidad, se ha venido regulando que "Durante los 03 primeros años contados desde la fecha de la suscripción del contrato, no pueden suscribirse adendas a los contratos de APP “(Decreto Supremo N 068-2017-EF, 2017) solo en 03 casos es factible; habiéndose recientemente incorporado un nuevo supuesto por "hechos sobrevinientes a la adjudicación de la buena pro que generen modificaciones imprescindibles para la ejecución del proyecto" dejándose sin efecto la anterior posibilidad de adendas por temas de bancabilidad. (por requerimiento de los acreedores permitidos).

Sin embargo, dichas medidas no han logrado aplacar los resultados adversos que se viene dando en los proyectos de inversión en nuestro país, que impide que concluyan satisfactoriamente lo cual no necesariamente responde a problemas en la implementación del modelo de APP sino a la mala gestión que se viene evidenciando en el sector público.

\subsubsection{Propuesta normativa que busca el fortalecimiento del control previo para que intervenga en las modificaciones contractuales, como un facilitador.}

En atención a lo expuesto, y como propuesta de solución se ha considerado vital "fortalecer el control previo que ejerce la Contraloría General de la República en el marco del Sistema Nacional de la Promoción de la Inversión Privada", para lo cual la propuesta normativa debe regular lo siguiente:

- Contraloría General de la República no solo intervendrá otorgando opinión previa respecto a la versión final del contrato sino también en torno a las modificaciones contractuales al Contrato de APP sea autofinanciada o cofinanciada (con garantía financiera o no financiera o ambas).

- La competencia para emitir opinión previa respecto a las modificaciones contractuales, será únicamente de aquellas operaciones que comprometen 
el crédito o la capacidad financiera del Estado; en concordancia con sus atribuciones reguladas en el literal 1) del artículo $22^{\circ}$ de la Ley $\mathrm{N}^{\circ} 27785$.

Entiéndase por "operaciones que comprometen el crédito o la capacidad financiera" lo regulado por el numeral 5.2 de la Directiva N. ${ }^{\circ} 012-2016$ CG/GPROD "Emisión del Informe Previo establecido por el literal 1) del artículo 22 de la Ley N. ${ }^{\circ} 27785$ ” aprobada por Resolución de Contraloría $\mathrm{N}^{\circ}$ 148-2016-CG, lo siguiente: “... aquellas operaciones financieras o no financieras que deriven en el incremento del stock y el servicio de la deuda externa o generen pasivos o compromisos firmes o contingentes para el estado, según sea el caso “ (p. 4)

Esta opinión previa sería no vinculante; sin perjuicio del control posterior que se pueda ejecutar; toda vez, que el "Control previo" como se ha señalado está entendido como una atribución que realiza CGR con anterioridad a la ejecución de un acto u operación por parte de una Entidad, a fin de emitir un resultado de acuerdo a la materia del requerimiento que realice la entidad solicitante. Este resultado u opinión nunca puede ser sobre hechos concluidos (control posterior) ni en ejecución (control simultáneo) siempre su atribución debe ser sobre proyectos ("proyecto de contrato", "proyecto de adenda").

- $\quad$ El plazo en que emitirá su opinión previa, consideramos que debe ser el que actualmente se rige para las otras entidades públicas en el artículo $57^{\circ}$ del Decreto Supremo N. ${ }^{\circ}$ 068-2017-EF que también participan, cada uno en el marco de sus competencias, es decir (10) días hábiles, buscando no generar una barrera burocrática sino cumplir su rol y ajustarse al plazo legal otorgado.

Sin embargo, de requerirse información adicional, consideramos que se debe darse un plazo adicional de cinco (05) días hábiles tan igual como se regula en la Directiva N. 012-2016-CG/GPROD "Emisión del Informe Previo establecido por el literal 1) del artículo 22 de la Ley N. ${ }^{\circ} 27785$ " aprobada por Resolución de Contraloría N 148-2016-CG, para el caso de opinión previa a la versión final del contrato. 
- Debe considerarse también que el incumplimiento del plazo otorgado para emitir opinión, conlleva que se entienda que ésta es favorable.

- La opinión previa a las modificaciones contractuales se dará una vez, que las entidades públicas participantes hayan concluido con la evaluación conjunta sobre la versión final del proyecto de addenda;

- Delimitar el rol de competencia que tiene el Ministerio de Economía y Finanzas, con las atribuciones que tiene Contraloría General de la República por cuanto en el artículo $57.2^{\circ}$ del Decreto Supremo N. ${ }^{\circ} 410$ 2015-EF se precisa que “... la entidad pública solicita la opinión previa favorable del Ministerio de Economía y Finanzas en caso de las modificaciones alteren el cofinanciamiento, las garantías así como ante cambios en los parámetros económicos y financieros del contrato, y aquellos cambios que puedan generar modificaciones al equilibrio económico financiero del contrato de Asociación Público Privada o puedan generar contingencias fiscales al Estado" (Decreto Supremo N. ${ }^{\circ}$ 410-2015-EF, 2015), resultando importante que no se confunda su rol netamente presupuestal con el análisis técnico - legal que realiza la Contraloría, en donde toma en cuenta todo el marco regulatorio existente al caso concreto; y solicita información adicional si el caso lo amerita .

Al respecto, recordemos el trámite que se realiza actualmente para la emisión del Informe previo a la revisión de la versión final de Contrato, el cual se grafica a continuación:

Figura 3.6

Emisión del informe previo de la Contraloría sobre operaciones, fianzas o avales que comprometan al Estado 


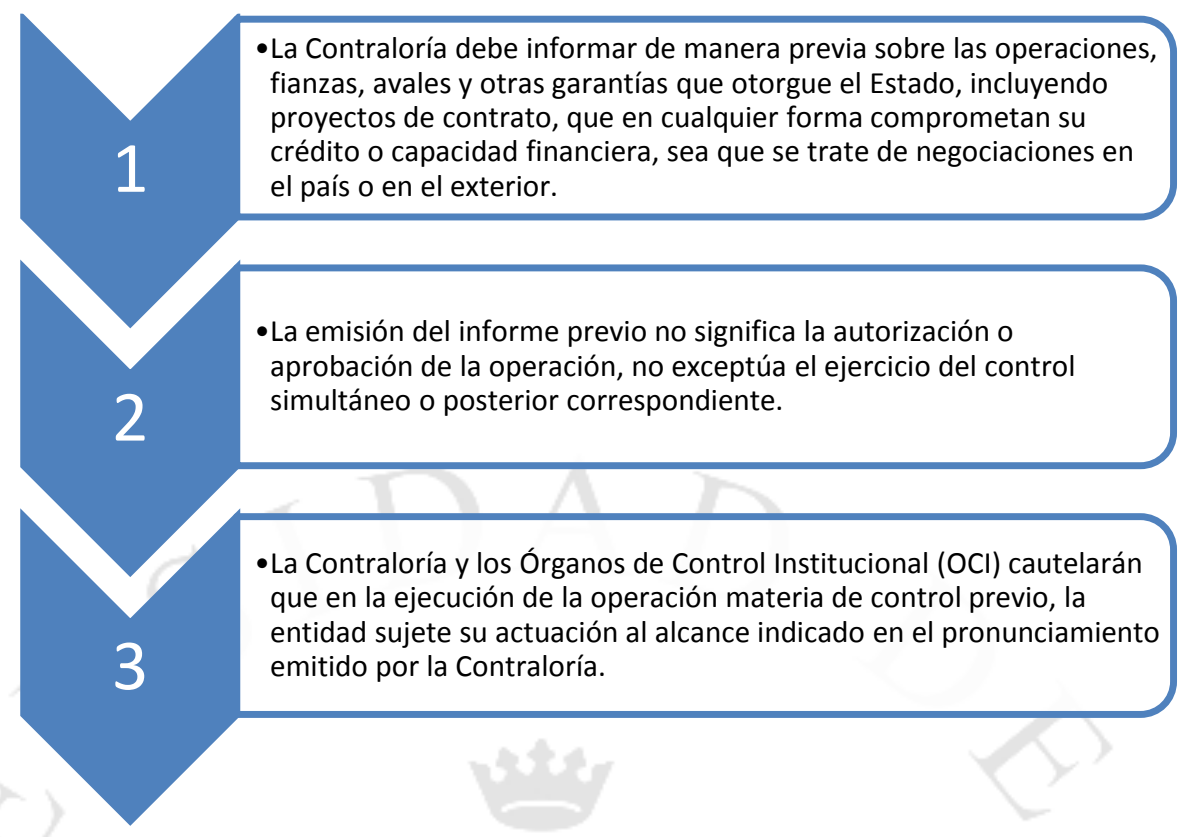

Fuente: Contraloría General de la República. (2015). Causas y efectos de las renegociaciones contractuales de las Asociaciones Público - Privadas en el Perú.

Este trámite sería el mismo que se seguiría para emitir opinión previa a la versión final de la adenda (proyecto de adenda) .

Respecto a la justificación del proyecto normativo - de fortalecer el control previo que ejerce la Contraloría General de la República en el Sistema Nacional de la Promoción de la Inversión Privada -, se debe señalar que existe un proyecto de Ley presentado por la Contraloría General de la República al Congreso de la República, del cual se han extraído algunos argumentos de sustento que se van a citarse a continuación:

- Existe la necesidad de disponer de una herramienta de control previo que nos permita detectar de manera oportuna los posibles riesgos que involucren las modificaciones que se deriven de la adenda de los contratos de APP.

- La detección no es el fin en sí mismo, lo que se busca como resultado final de la intervención de la CGR es que la administración pública pueda adoptar oportunamente medidas preventivas o implementar medidas correctivas en salvaguarda de los intereses del estado. Lo cual no solo se beneficia el estado sino también contribuye así a garantizar la confianza de los inversionistas y de la ciudadanía en general. 
- El control es una parte imprescindible en la administración dado que instala un mecanismo regulador que debe señalar oportunamente las desviaciones normativas para su corrección; así como las infracciones que podrían conllevarse. De tal forma, que independientemente de la implementación de las alertas también se convierte en un disuasivo frente a reiteración de dichos comportamientos sin sustento.

- Se busca que sea una herramienta que permita ejercer el control gubernamental de manera oportuna, contribuyendo como un facilitador a la disminución de los riesgos que involucren las operaciones de renegociación, en salvaguarda de la seguridad jurídica y de las inversiones privadas. Así como de posibles perjuicios económicos en detrimento del Estado.

- Contraloría no busca ser un obstaculizador sino un facilitador que tiene una experiencia técnica ganada, profesionales capacitados y una unidad orgánica multidisciplinaria atenta al reto que va a conllevar esta propuesta normativa.

- Esta propuesta nace ante la impotencia de CGR de ver que las principales actuaciones de corrupción se vienen dando en la etapa de ejecución contractual; sin embargo su marco legal no le permite ingresar mediante control previo a alertar o prevenir para que los proyectos no se paralicen o caduquen, cautelando los intereses del Estado.

\subsubsection{Proyecto de ley de propuesta normativa en el Congreso de la República.}

Existe el Proyecto de Ley N. ${ }^{\circ}$ 27/2016-CG presentado el 12 de agosto de 2016 por la Contraloría General al Congreso de la República; el mismo que ha sido derivado a la Comisión de Fiscalización y Contraloría del Congreso de la República como primera Comisión Dictaminadora y la Comisión de Economía, Banca, Finanzas e Inteligencia Financiera como segunda Comisión Dictaminadora. Luego de la exposición y debates en la Octava Sesión Ordinaria de fecha 26 de octubre de 2016 se acordó por unanimidad la aprobación del texto sustitutorio del proyecto de ley. 
Se plantea modificar el artículo $16^{\circ}$ y el artículo $22^{\circ}$ del Decreto Legislativo 1224, Decreto Legislativo del Marco de Promoción de la Inversión Privada mediante APP y proyectos en activos, proponiendo el siguiente texto:

Artículo $16^{\circ}$. Opiniones previas

\section{$(\ldots)$}

16.2 El Informe previo de la Contraloría General de la República respecto de la versión final del contrato de Asociación Público Privada, así como de las modificaciones contractuales que correspondan, únicamente podrá referirse sobre aquéllos aspectos que comprometan el crédito o la capacidad financiera del Estado de conformidad con el inciso i) del artículo 22 de la Ley $\mathrm{N}^{\circ} 27785$, Ley Orgánica del sistema Nacional de Control y de la Contraloría General de la República. Dicho Informe Previo no es vinculante, sin perjuicio de control posterior.

Como advertimos solo se incorpora el texto " así como las modificaciones contractuales que correspondan "a la propuesta legal existente; precisándose que esta propuesta normativa tiene como objeto fortalecer el control gubernamental en la emisión del Informe previo establecido en el literal i) del artículo $22^{\circ}$ de la Ley N. ${ }^{\circ} 22785$, Ley Orgánica del Sistema Nacional de Control y de la Contraloría General de la República, respecto a las modificaciones de los contratos de asociaciones Público Privadas suscritos en el marco del Decreto Legislativo N. ${ }^{\circ}$ 1224, decreto legislativo del Marco de Promoción de la Inversión Privada mediante APP y proyectos en activos. Encontrándose pendiente su aprobación hasta la fecha.

Esta propuesta normativa, posteriormente a la sustentación de Tesis, fue aprobada mediante Ley $\mathrm{N}^{\circ} 30594$ - "Ley que modifica el Decreto Legislativo $\mathrm{N}^{\circ} 1251$, Decreto Legislativo que modifica el Decreto Legislativo $N^{\circ} 1224$, Ley Marco de Promoción de la Inversión Privada mediante Asociación Público Privadas y Proyectos en Activos" publicada en el diario oficial El Peruano el 24 de junio de 2017. Este hecho valida y ratifica el presente trabajo de investigación efectuado.

\subsection{Caso de Estudio: Contrato de Concesión para el nuevo Aeropuerto de Chinchero - Cusco.}


Este caso de estudio del contrato de Concesión para el Aeropuerto Internacional de Chinchero en Cusco, se ha considerado por cuanto aquí la participación técnica de la Contraloría General fue determinante desde un enfoque principalmente de control previo más que de control posterior (determinación de responsabilidades).

Ello principalmente porque existió un informe Previo n. ${ }^{\circ}$ 00027-2014-CG/PRE que fue determinante. Asimismo, una orientación de Oficio $\mathrm{N}^{\circ}$ 1882-2016-CG/DC de 12 de octubre de 2016 (control simultáneo ante la imposibilidad de poder ejercer el control previo) respecto al trámite de autorización del endeudamiento Garantizado Permitido del Contrato de Concesión; y finalmente otra Orientación de Oficio N. ${ }^{\circ}$ 00331-2017-CG/DC de 22 de febrero de 2017 respecto al pago de adelanto previsto en la Adenda n. ${ }^{\circ} 01$ del Contrato de Concesión; que si se hubieran implementado correctamente en su oportunidad no estaríamos hablando de los efectos adversos que ha tenido la suscripción de la adenda; debiendo el Poder ejecutivo actuar en el marco de su competencia exigiendo al consorcio Kuntur Wasi el debido cierre financiero, caso contrario proceder a la caducidad.

Resulta vital, tener en cuenta brevemente la siguiente descripción del proyecto:

- 11 de octubre de 2011, mediante Ley 27529, se creó el Proyecto Especial Aeropuerto Internacional de Chinchero - Cusco (NAICC), declarado de necesidad y utilidad pública y alta prioridad para el Estado.

- El proyecto comprende: Diseño, financiamiento, construcción, operación y mantenimiento del NAICC.

- PROINVERSIÓN canalizó el proyecto como una APP cofinanciada.

- Plazo de concesión: 40 años.

- Factor de competencia: FPAO y \% de reintegro.

- Concedente: MTC

- Entidad supervisora: OSITRAN

Asimismo, respecto a sus principales características tenemos: 
- Modalidad bajo la cual se otorga la Concesión fue Cofinanciada por el Estado. El proceso estuvo a cargo de PROINVERSIÓN por encargo del MTC. Siendo que la convocatoria se dio en Agosto 2010

- Valor de Fondo de Pagos consignado en el anexo 7, apéndice 1 de las bases del concurso: Monto de US\$ 457,489,504.00 como tope máximo.

- Acto de recepción de propuestas: 22ABR2014

- $\quad$ Acto de apertura de sobres: 25ABR2014

- Buena pro: Consorcio Kuntur Wasi, conformado por las empresas Corporación América S.A. y Andino Investment Holding S.A.

Principales comentarios en torno, a lo acontecido en el Contrato de Concesión

\section{$\underline{\text { Respecto al Contrato: }}$}

- Existieron alertas a la versión final del Contrato (Informe Previo N. ${ }^{\circ}$ 0272014-CG/PRE de CGR a PROINVERSIÖN, MTC, OSITRAN y CORPAC) que no fueron consideradas.

- No se fijó un plazo de presentación del cierre financiero solicitándole a PROINVERSION que se realice antes de la adjudicación de la buena pro.

- No se fijó una Tasa máxima de Endeudamiento para el cálculo del PAO.

- Los estudios de Perfil y Factibilidad desarrollados en el marco SNIP no analizaron otras alternativas para la ubicación del aeropuerto. (Estudio de Macro localización del Proyecto)

- No se ha acreditado en el caso del acreedor permitido cuente con la autorización del Concedente para acreditar dicha condición, cuya intervención debe estar aprobada por el Concedente, previa opinión del OSITRAN en el marco del endeudamiento garantizado.

\section{$\underline{\text { Respecto al Endeudamiento Garantizado Permitido }}$}


- Existió orientación de Oficio mediante Oficio n. ${ }^{\circ}$ 1882-2016-CG/DC de 12 de octubre de 2016 de CGR en aras de que se verifique la opinión de Ositran de enero de 2014 (en la cual se detalla el esquema de aplicación de los intereses para calcular la tasa de endeudamiento) que fue de conocimiento y por tanto exigible a los postores.

- No se ha advertido que Goldman Sachs \& Co. tenía la autorización del MTC (Concedente) para ser Acreedor Permitido, según lo establecido en el Contrato.

- No se verificó la razonabilidad de no haber considerado el Cierre Financiero para la Sub etapa 1 y para la Sub etapa 2, siendo que en ambos casos el Concesionario debe conseguir recursos para su ejecución.

Con lo cual se plantea un esquema de contrato original de esta forma:

Figura 3.7.

Esquema del Contrato original de Chinchero
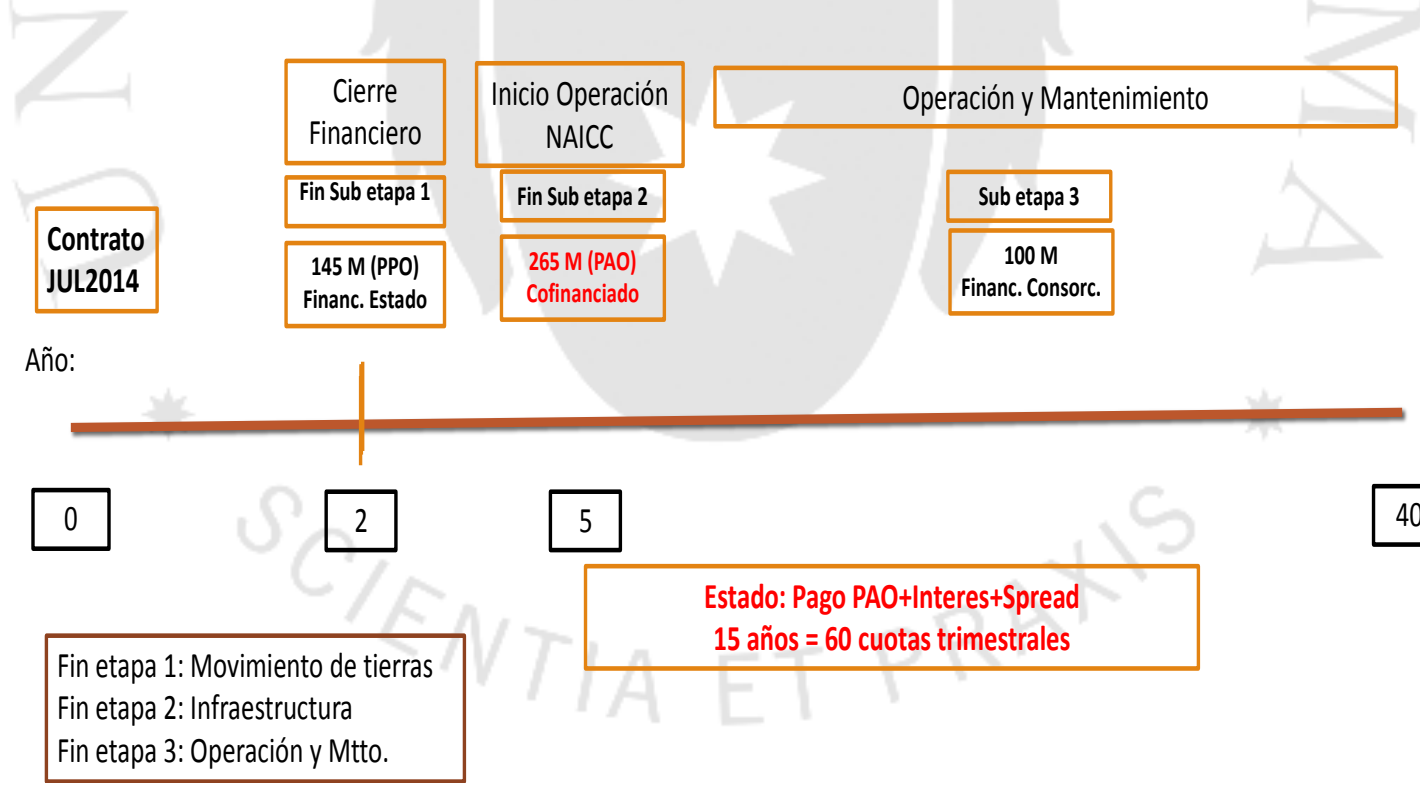

Fuente: Bases y Contrato de Concesión del nuevo Aeropuerto Internacional Jorge Chávez.

\section{Respecto a la suscripción de la Adenda:}


- No queda claro si la causal invocada (b) Requerimientos sustentados de los Acreedores Permitidos vinculados a la etapa de Cierre Financiero del Contrato) para el trámite de la adenda, se respetó para definir el texto final de la Adenda $\mathrm{N}^{\circ} 1$.

- Asimismo, si se verificó que todas las cláusulas hayan dado estricto cumplimiento a la citada causal (b) para las modificaciones contractuales antes de los 3 primeros años.

- No se advierte una evaluación cuantitativa de los efectos que las modificaciones en el esquema de pagos tendrían en el modelo del Equilibrio Económico - Financiero, debido a que los informes que sustentan la Adenda $\mathrm{N}^{\circ} 1$ señalan solamente de manera enunciativa que dicho equilibrio se mantiene.

- No queda claro porqué se estableció el monto para el Adelanto; así como la pertinencia de haber considerado su entrega al Concesionario 30 días antes de la ejecución de la Sub Etapa 1 cuando lo que se está discutiendo es la Sub Etapa 2.

- Se advierte que se realizó un análisis de "Beneficios Sociales" del proyecto, cuando para el caso de las APP corresponde realizar una evaluación del Valor por Dinero.

- No se entiende la razonabilidad de haber mantenido la denominación de FPAO, si se eliminaron todas las referencias al PAO. ¿Su eliminación habría modificado las condiciones de competencia del proceso de promoción?.

- Evaluar las consecuencias de haber modificado los siguientes parámetros o condiciones de competencia del proceso de promoción: Variación del esquema de pago, otorgamiento de adelanto al Concesionario, modificación de la fecha del Cierre Financiero, y aceptación de Cartas Fianza otorgada por empresas aseguradoras.

- Al no establecerse una Tasa máxima de endeudamiento el Concesionario interpretó que no incluía intereses intercalares sumando una tasa de $22 \%$ que hacía que el proyecto se incremente a US\$ 500 millones. 
- Lo cual debió ser utilizado por el Estado por cuanto al no poder hacer su cierre el Concesionario debió alegar Caducidad, máxime si era de conocimiento de las partes lo señalado como Tasa por Ositran $9.5 \%$ que ya incluía los intereses intercalares.

- No debió aceptarse la causal invocada (b) Requerimientos sustentados de los Acreedores Permitidos vinculados a la etapa de Cierre Financiero del Contrato) para el trámite de la adenda.

- Existen opiniones contradictorias (MTC - Proinversión - Ositran) durante la sustentación del trámite de Endeudamiento Garantizado Permitido y de la evaluación del proyecto de Adenda; que hace generar duda de niveles de corrupción. Siendo que la CGR en uso de sus atribuciones, ha considerado conveniente y oportuno programar de manera inmediata un servicio de control posterior con alcance desde el inicio del proceso de promoción hasta la suscripción de la Adenda $\mathrm{N}^{\circ} 1$.

Lo expuesto conllevó que el esquema del contrato original cambiara por un contrato de adenda que se grafica a continuación:

Figura 3.8.

Esquema del Contrato con la Adenda N. ${ }^{\circ} 01$ 


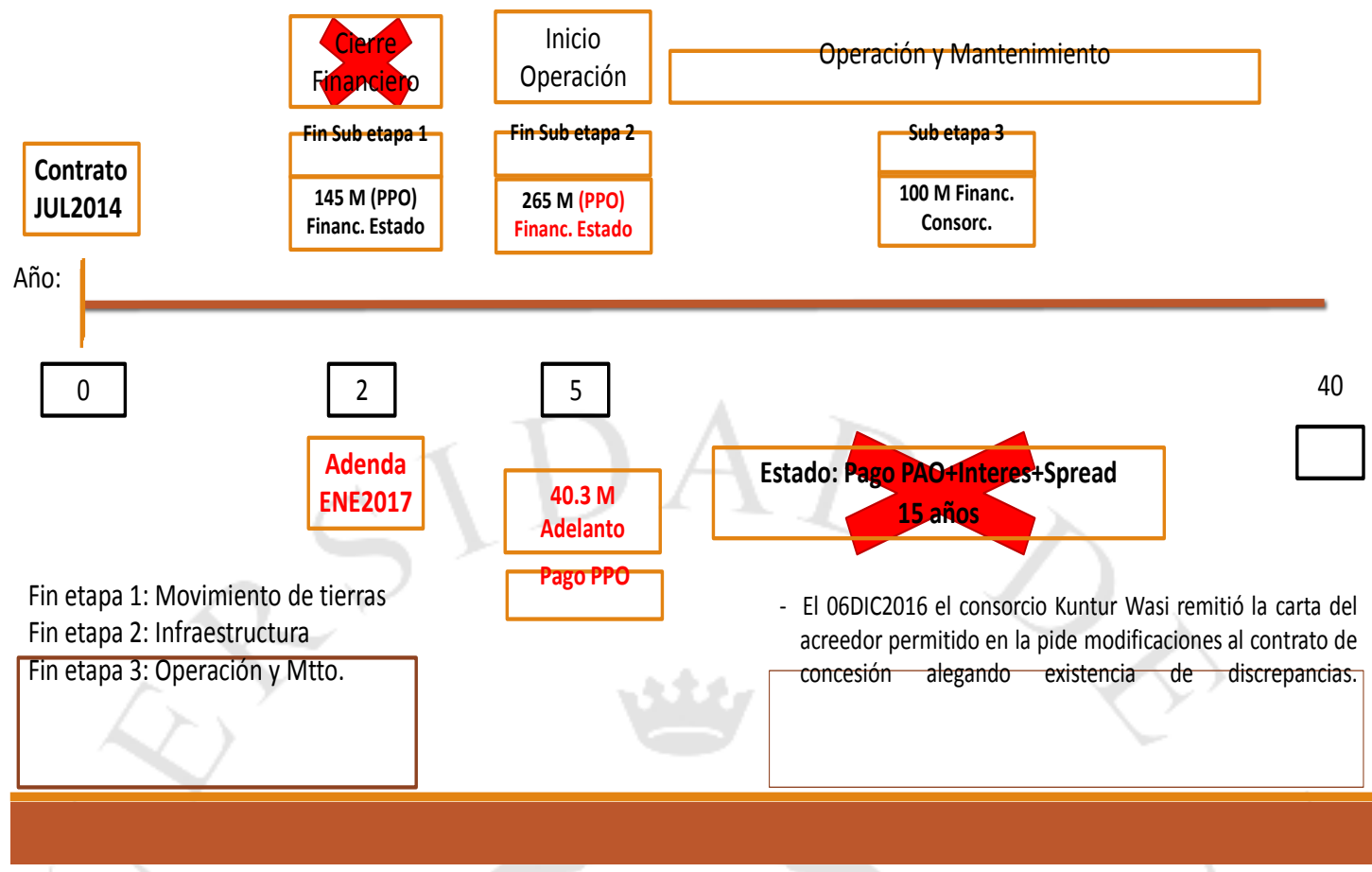

Fuente: Adenda del Contrato de Concesión del nuevo Aeropuerto Internacional Jorge Chávez 


\section{CONCLUSIONES}

A continuación detallamos las conclusiones a las que hemos llegado a partir de nuestra investigación:

- Conclusión 1: El modelo económico británico comenzó a difundirse a finales de los años noventa teniendo mayor auge en los últimos años, conocido como asociaciones público privadas o alianzas público privadas (APP) en donde su principal característica es la distribución y mitigación de riesgos entre las partes público (a nivel de los tres niveles de gobierno) y privado intervinientes en función a la mejor capacidad que tengan cada una de ellas para administrarlo. El escenario de globalización mundial ha influenciado notablemente el desarrollo económico social de los países que la han adoptado, frente a restricciones presupuestarias y de inversión pública que siguen existiendo.

- Conclusión 2: Con las APP se busca no solo mejorar la prestación de servicios públicos y proveer de la infraestructura que exige el país, sino también elevar los niveles de vida y bienestar de los ciudadanos a largo plazo; más si tenemos en cuenta que ello se agudiza en determinados sectores más que otros, por cuanto como es de conocimiento - a inicios del 2017 los desastres naturales (lluvias y huaycos) azotaron a nuestro país, afectaron a diversas regiones principalmente a la zona norte, que tuvieron que ser declaradas en emergencia; con lo cual el proceso de reconstrucción viene a agravar el déficit de infraestructura y mejora de los servicios públicos que ya existía.

- Conclusión 3: El Perú ofrece un marco legal para las asociaciones público-privada que busca motivar la inversión extranjera, en aras de que se constituya en un mecanismo que permita al Estado evitar o diferir el gasto que existe por el déficit en infraestructura y mejora de servicios públicos pero sin renunciar a los beneficios o bondades que conlleva su implementación.

- Conclusión 4: Existe la necesidad de contar con políticas de Estado claras y públicas; que puedan definir cuáles son las prioridades de gobierno - en un Estado peruano lleno de necesidades - para que sobre ello los proyectos de promoción de 
la inversión privada mediante APP pueda contribuir con el Estado en atender las demandas y necesidades esenciales de la población; caso contrario, no se advierte si la necesidad de incorporar experiencia, conocimientos, equipos especializados, y tecnología del sector privado está logrando resultados que impacten positivamente en el bienestar del ciudadano.

- Conclusión 5: Lamentablemente, hoy por hoy al planeamiento estratégico el Estado peruano le resta importancia, cada sector puede manejar el propio pero éstos no son construidos sobre la base de uno integrado como país; con lo cual se desconoce cuál es el propósito a ser alcanzado, no se tiene un norte claro y que a su vez, perdure en el tiempo como política de Estado y no de gobierno. Dicha situación conlleva que la ciudadanía no pueda sentir o advertir el beneficio que se está generando con la implementación de una política y cómo vamos avanzando en el cumplimiento de nuestros objetivos como país.

- Conclusión 6: En la práctica, no se logra utilizar el planeamiento como una herramienta efectiva de gestión y no se articula el planeamiento con el presupuesto; es decir, sin un norte claro el Estado peruano no puede saber si lo que viene implementando o disponiendo como política de Estado - a través de la promoción de la inversión privada mediante APP - está contribuyendo a reducir las brechas sociales y económicas; así como de infraestructura que exige el país.

- Conclusión 7: La reforma PpR exige cambios drásticos a la administración pública, la cual no estuvo acostumbrada a estructurarse y a operar en función a resultados que impacten positivamente en beneficio del ciudadano. Este cambio plantea un desafío significativo para ella, induciéndola a repensar sus objetivos, estrategias, intervenciones, sistemas administrativos, y alianzas estratégicas con el sector privado en términos del ciudadano.

- Conclusión 8: Lo que busca en una cadena de valor es procurar generar el mayor valor posible en cada una de las actividades desagregadas, y al mismo tiempo procurar minimizar los costos sin lesionar calidad en cada una de éstas; con lo cual se logra obtener el mayor margen de utilidad posible (value for money). De lo que se trata es de generar valor público, diferente de lo que se busca en el sector privado, cuyo valor es generar mayores utilidades (valor privado). 
- Conclusión 9: El desarrollo de un proyecto implica todo un proceso productivo que nace desde una necesidad priorizada que atender diseñada en una política pública (escasos recursos y múltiples requerimientos) para lo cual teniendo clara la planificación y su resultado se asigna el presupuesto y los insumos; ello para que permita se realice actividades ya definidas, lo cual dará lugar a bienes o servicios (producto). Estos productos al ser recibidos por la población beneficiaria generan un resultado a mediano y largo plazo; sin embargo, el Estado espera que sean la solución al problema o que generen la eliminación de la necesidad que le dio origen. Para el logro de dicho resultado resulta vital el seguimiento y evaluación que me permitirá contar con alertas tempranas durante todo el ciclo del servicio o bien a fin de tomar decisiones o medidas correctivas informadas; y a su vez, los indicadores permitirán evaluar si se viene cumpliendo con lo planificado, en aras de lograr el impacto positivo en el bienestar del ciudadano.

- Conclusión 10: Se debe estar alertas al rol de competencias que viene teniendo Proinversión y el Ministerio de Economía y Finanzas (MEF). Si bien se ha logrado definir sus funciones; el MEF como ente rector de la política Nacional en temas de APP desarrolla aspectos de planificación estratégica que sobrepasan sus competencias presupuestales y en los que principalmente deban participar los sectores. Aunado a ello, consideramos que el haber otorgado mayor responsabilidad en Proinversión al Director Ejecutivo que al Consejo Directivo, genera un cuello de botella y un alto nivel de responsabilidad para un solo funcionario que difícilmente puede advertir temas técnicos a detalle en los procesos de promoción de la inversión privada en APP, previamente a aprobarlos.

- Conclusión 11: En los casos de coyuntura social expuestos, se advierte una muestra de la problemática que viene suscitándose en el Estado peruano desde la planificación de los proyectos, que como producto de renegociaciones no solo se han generado perjuicios económicos sino afectación a la institucionalidad de las APP y un pésimo mensaje a la inversión extranjera de problemas de corrupción y favorecimiento a concesionarios. Este aspecto será también ampliado en el capítulo II del presente trabajo de investigación. 
- Conclusión 12: El control gubernamental constituye una herramienta efectiva para la gestión pública; y a su vez, el rol que ejerce la CGR resulta fundamental, debiendo ser visto como un socio estratégico para que el Estado logre sus objetivos con el resultado e impacto esperado en el ciudadano; sin embargo, hay que tener en cuenta que constituye una labor dinámica y técnica, que debe ser continuamente mejorada según los cambios y riesgos que la Entidad enfrente y no solo segmentarse a una evaluación de cumplimiento normativo; así como el personal auditor debe estar en constantes capacitaciones, con el objeto de asegurar que lo que se recomiende en los Informes de Control producto del cierre del servicio de control estén de acuerdo con los objetivos de política nacional, entorno, y resultados esperados por el sector.

- Conclusión 13: Es frente a esta problemática, que nuestra normativa sobre APP ha venido regulando y estableciendo candados institucionales al tema de las "modificaciones contractuales" (adendas) pese a que es una potestad válida entre las partes, máxime si se trata de contratos a largo plazo. Ello siempre y cuando se mantenga el equilibrio económico financiero y las condiciones de competencia del proceso de promoción, no debiendo alterar las adendas la asignación de riesgos y la naturaleza del proyecto.

- Conclusión 14: Como propuesta de solución se ha considerado vital "fortalecer el control previo que ejerce la Contraloría General de la República en el marco del Sistema Nacional de la Promoción de la Inversión Privada dado que existe la necesidad de disponer de una herramienta de control previo que nos permita detectar de manera oportuna los posibles riesgos que involucren las modificaciones que se deriven de la adenda de los contratos de APP. Siendo que la detección no es el fin en sí mismo, lo que se busca como resultado final de la intervención de la CGR es que la administración pública pueda adoptar oportunamente medidas preventivas o implementar medidas correctivas en salvaguarda de los intereses del estado. Lo cual no solo se beneficia el estado sino también contribuye así a garantizar la confianza de los inversionistas y de la ciudadanía en general. 


\section{RECOMENDACIONES}

Entre nuestras principales recomendaciones tenemos:

- Recomendación 1: Impulsar la aprobación de la propuesta normativa desde mi centro de labores dado que urge la necesidad de disponer de una herramienta de control previo que nos permita detectar de manera oportuna los posibles riesgos que involucren las modificaciones que se deriven de la adenda de los contratos de APP. (Lo cual posteriormente a la sustentación de Tesis, se aprobó mediante Ley $\mathrm{N}^{\circ}$ 30594 publicada en el diario oficial El Peruano el 24 de junio de 2017 ratificando el trabajo de investigación efectuado).

- Recomendación 2: Fomentar la implementación de Asociaciones Público Privadas en los tres niveles de gobierno, pero principalmente focalizar a nivel regional y local para el mejoramiento de los diseños de los proyectos de APP, aprovechando algunas experiencias internacionales y locales.

- Recomendación 3: Exigir en el diseño y estructura de los proyectos, un mayor análisis e identificación de todos los riesgos, con apoyo entre otros de expertos financieros, ingenieros, técnicos y especialistas en administración pública; de tal forma que se pueda determinar la utilidad social del mismo y si es viable ir por APP, así como estándares de calidad y niveles de servicio; lo que permitiría la asignación y distribución adecuada de los riesgos; con lo cual se evitaría futuras renegociaciones ineficientes, un incremento en los costos del proyecto y el descontento social ante el retraso en la entrega de los mismos.

- Recomendación 4: Incentivar la participación de la iniciativa privada a través de la formulación de propuestas de inversión acordes a los estudios de las necesidades de la realidad nacional, es importante tener un "Banco de Proyectos de Inversión", y de los cuales el Estado pueda seleccionar los que proponen soluciones a los problemas de política nacional. 
- Recomendación 5: La APP es una herramienta que no va a solucionar nuestra problemática si es que paralelamente el Estado no fortalece sus capacidades internas que le permitan gestionar los diferentes contratos de APP; así como soluciona los problemas que surgen con la expropiaciones. Ello en aras de lograr un crecimiento sostenible y equitativo que promueva la inversión orientada a mejorar la calidad de vida de los ciudadanos.

- Recomendación 6: Establecer indicadores de impacto, que midan los efectos del proyecto en los bienes y calidad de vida de los usuarios, buscando cambiar la visión de las APP que no solo se concentraría en la inversión sino también en niveles de servicio; así como el impacto que el acceso a la infraestructura o al servicio público generaría en el ciudadano.

- Recomendación 7: Con la finalidad de generar transparencia y un control social, las entidades públicas de los tres niveles de gobiernos deben publicar de oficio en sus respectivas páginas web institucionales la relación de proyectos de APP que se encuentran bajo su responsabilidad, así como su estado situacional. Esta rendición de cuentas por resultados busca que la ciudadanía y demás entidades público o privadas puedan tener conocimiento del avance y gestión de los proyectos. 


\section{REFERENCIAS}

Alborta, G., Stevenson, C. y Triana, S. (2011). Asociaciones público-privadas para la prestaciones de servicios. Una visión hacia el futuro.[Versión PDF].

Recuperado de

http://services.iadb.org/wmsfiles/products/Publications/36514441.pdf

Acuña, R., Huaita, F. y Mesinas. J. (2012). En camino de un Presupuesto por Resultados (PpR). Una Nota sobre los Avances recientes en la programación Presupuestaria. Documento de Gestión Presupuestaria DGP 02/2012, 1-21. Recuperado de https://www.mef.gob.pe/contenidos/presu_publ/estudios/En_camino_de_un_Pp $\underline{\text { R.pdf }}$

Banco Interamericano de Desarrollo - BID. (2009). Asociaciones público Privadas para el Desarrollo de Infraestructura y provisión de servicios públicos [Versión PDF]. Recuperado de https://publications.iadb.org/bitstream/handle/11319/3663/Experiencia\%20brit\% C3\%A1nica\%20en\%20el\%20desarrollo\%20de\%20proyectos\%20de\%20APP.pd f? sequence $=1$.

Bessombes, C. (Edición impresa el 24 de junio de 2013). La apuesta por la Asociación Público Privada en el Perú. La República. Recuperado de http://larepublica.pe/24-06-2013/la-apuesta-por-la-asociacion-publico-privadaen-el-peru

Casado Cañeque, F. (2007). Alianzas público privadas para el desarrollo. Documento de Trabajo N. 9 (1. ${ }^{\mathrm{a}}$ ed.). Madrid: Fundación Carolina- CeALCI [Versión PDF]. Recuperado de https://www.fundacioncarolina.es/wpcontent/uploads/2014/08/DT9.

Centro Nacional de Planeamiento Estratégico - Ceplan (eds.). (2015). Directiva General del Proceso de Planeamiento Estratégico - Sistema Nacional de Planeamiento Estratégico. Lima. 
Contraloría General de la República. (2015). Causas y efectos de las renegociaciones contractuales de las Asociaciones Público - Privadas en el Perú. Perú- Lima [Versión PDF]. Recuperado de http://doc.contraloria.gob.pe/estudiosespeciales/estudio/2015/Estudio_renegociaciones_contractuales_APP

Contraloría General de la República. (2016). Control Previo .Perú- Lima pp. 1-8. Recuperado de http://doc.contraloria.gob.pe/PACK_anticorrupcion/documentos/4_CONTROL_ PREVIO_2016.pdf

Contraloría General de la República. (2015). Guía de Auditoría de Cumplimiento. PerúLima pp. 1-123. Recuperado de http://doc.contraloria.gob.pe/libros/2/pdf/Guia_Auditoria_Cumplimiento_Asoc Publ_Privadas.pdf

Decreto Legislativo N. ${ }^{\circ}$ 674, Ley de Promoción de la Inversión Privada en las Empresas del Estado. (1991). Recuperado del sitio de internet del Congreso de la

República: http://www.leyes.congreso.gob.pe/Documentos/DecretosLegislativos/00674.pdf

Decreto Supremo $\mathrm{N}^{\circ}$ 127-2014-EF, 2014.Aprueban Reglamento del Decreto Legislativo No 1012 que aprueba la Ley Marco de Asociaciones Público Privadas para la Generación del Empleo Productivo y dicta Normas para la agilización de los Procesos de Promoción de la Inversión Privada. (2014). Recuperado del sitio de internet del Ministerio de Economía y Finanzas:

https://www.mef.gob.pe/contenidos/inv_publica/docs/normas/normasv/privada/ 2014/Reglamento_de_la_Ley_de_APP_(31-05-2014).pdf

Decreto Legislativo N. ${ }^{\circ}$ 1012. Decreto Legislativo que aprueba la Ley Marco de Asociaciones Público Privadas para la generación de empleo productivo y dicta normas para la agilización de los procesos de promoción de la inversión privada (2008). Recuperado del sitio de internet del Ministerio de Economía y Finanzas: https://www.mef.gob.pe/contenidos/inv_publica/docs/normas/normasv/privada/ 2014/DL-1012-actualizado-al-02-03-2014j.pdf 
Decreto Legislativo N. ${ }^{\circ}$ 1224. Del Marco de Promoción de la Inversión Privada mediante Asociaciones Público Privadas y Proyectos en Activos (2015). Recuperado del sitio de internet del Diario El Peruano: http://www.elperuano.com.pe/NormasElperuano/2015/09/25/1292138-3.html

Decreto Legislativo n. ${ }^{\circ}$ 1251. Modifica el Decreto Legislativo N. ${ }^{\circ} 1224$ Ley Marco de Promoción de la Inversión Privada mediante Asociaciones Público privadas y Proyectos en Activos. (2016). Recuperado del sitio de internet del Diario El Peruano: http://busquedas.elperuano.com.pe/normaslegales/decreto-legislativoque-modifica-el-decreto-legislativo-n-1-decreto-legislativo-n-1251-1458990-2/

Decreto Supremo N. ${ }^{\circ}$ 109-2012-PCM, Aprueban la Estrategia para la modernización de la gestión Pública. ((31 de octubre de 2012) Recuperado de Normas Legales del Diario Oficial El Peruano. http://www.pcm.gob.pe/normaslegales/2012/DS1092012-PCM.pdf

Decreto Supremo N. ${ }^{\circ}$ 004-2013-PCM, Aprueba la política Nacional de Modernización de la gestión Pública. ((08 de enero de 2013). Recuperado de Normas Legales del Diario Oficial El Peruano.

http://busquedas.elperuano.com.pe/normaslegales/aprueba-la-politica-nacionalde-modernizacion-de-la-gestion-decreto-supremo-n-004-2013-pcm-886510-1/

Decreto Supremo N. ${ }^{\circ} 410-2015-E F$. Aprueban Reglamento del Decreto Legislativo N. ${ }^{\circ}$ 1224, Decreto Legislativo del Marco de Promoción de la Inversión Privada mediante Asociaciones Público Privadas y Proyectos en Activos (2015). Recuperado del sitio de internet del Diario El Peruano: http://busquedas.elperuano.com.pe/normaslegales/aprueban-reglamento-deldecreto-legislativo-n-1224-decreto-decreto-supremo-n-410-2015-ef-1327567-5/

Decreto Supremo N. ${ }^{\circ}$ 068-2017-EF. Modifican el Decreto Supremo N. ${ }^{\circ}$ 410-2015-EF, Reglamento del Decreto Legislativo N. ${ }^{\circ}$ 1224, Ley Marco de Promoción de la Inversión Privada mediante Asociaciones Público Privadas y Proyectos en Activos (2017). Recuperado del sitio de internet del Diario El Peruano: http://busquedas.elperuano.com.pe/normaslegales/modifican-el-decreto- 
supremo-n-410-2015-ef-reglamento-del-decreto-supremo-n-068-2017-ef$\underline{1502195-2 /}$

EY Building a better working world. (2016).Cómo las APPs pueden ayudar a los Gobiernos a cerrar la "brecha" a pesar de las limitaciones financieras. En EY Perú Library (Eds.), Las Asociaciones Público - Privadas y el desafío global en infraestructura. (pp 1-13). Perú. Recuperado de http://www.ey.com/Publication/vwLUAssets/Apps_desaf\%C3\%ADo_global_infr aestructura/\$FILE/EY-apps-desaf\%C3\%ADo-global-infraestructura.pdf

Elegir con cuidado la modalidad con que se adjudican las concesiones evita que el privado pida adendas. (06 de noviembre de 2015). Gestión. Recuperado de http://gestion.pe/economia/elegir-cuidado-modalidad-que-se-adjudicanconcesiones-evita-que-privado-pida-adendas-2147676

Gálvez Córdova, V. (18 de enero 2017). ¿Chinchero porque se discute tanto la adenda del proyecto?. El Comercio. Recuperado de http://elcomercio.pe/economia/peru/chinchero-discute-adenda-proyecto-232474

García, R. y García, M.(2010). La gestión para Resultados en el Desarrollo. En Banco Interamericano de Desarrollo (Eds.), La Gestión para Resultados en el desarrollo: Avances y desafíos en América Latina y el Caribe (pp. 5-8).

Gobierno debería renegociar contrato del Gasoducto al sur (11 de agosto de 2016). Gestión. Recuperado de http://gestion.pe/opinion/gobierno-deberia-renegociarcontrato-gasoducto-al-sur-2167505

Gobierno pone fin a la Concesión del Gasoducto Sur Peruano,, (23 de enero de 2017). El Comercio. Recuperado de: http://elcomercio.pe/economia/negocios/gobiernopone-concesion-gasoducto-sur-peruano-160547

Hurtado de Mendoza, C. LAP podría administrar el Aeropuerto Jorge Chávez hasta el 204. (13 de setiembre de 2016). El Comercio. Recuperado de : http://elcomercio.pe/economia/dia-1/lap-administrar-aeropuerto-jorge-chavez$\underline{2041-257740 ? \mathrm{ref}=\mathrm{ecr}}$ 
Organización Internacional de Entidades Fiscalizadoras Superiores -INTOSAI. A cerca de nosotros. Recuperado de sitio internet http://www.intosai.org/es/acerca-de-nosotros.html

Organización Internacional de Entidades Fiscalizadoras Superiores -INTOSAI. ISSAI 5225. Lineamiento para mejor práctica en la Auditoría de Financiamiento Público/ Privado y Concesiones. Recuperado del sitio internet:

http://www.intosai.org/es/issai-executive-summaries/detail/article/issai-5220guidelines-on-best-practice-for-the-audit-of-publicprivate-finance-and$\underline{\text { concessions.html }}$

Organización Internacional de Entidades Fiscalizadoras Superiores -INTOSAI. ISSAI 5240.. Directrices sobre las mejores prácticas para la auditoría de riesgo en los partenariados público/privados (PPP). Recuperado del sitio internet http://www.intosai.org/es/issai-executive-summaries/detail/article/issai-5240guideline-on-best-practice-for-the-audit-of-risk-in-publicprivate-partnershipppp.html

Ley $N^{\circ} 27785$, Ley orgánica del Sistema Nacional de Control y de la Contraloría General de la República. (22 de julio de 2002).Recuperado del sitio internet del Diario El Peruano: http://www.oas.org/juridico/PDFs/mesicic5_per_24_ley_27785.pdf

Ley $\mathrm{N}^{\circ}$ 27658, Ley Marco de Modernización de la Gestión Pública. (17 de enero de 2002). Recuperado del sitio de internet del Congreso de la República del Perú http://www2.congreso.gob.pe/sicr/cendocbib/con4_uibd.nsf/BCE7AB2E6434B5 5305257B890053B271/\$FILE/02A08.pdf

Ley $\mathrm{N}^{\circ}$ 30335. Ley que delega en el Poder Ejecutivo la facultad de legislar en materia Administrativa, Económica y Financiera. (2015). Recuperado del sitio de internet del Diario $\quad$ El http://www.elperuano.com.pe/NormasElperuano/2015/07/01/1257199-1.html

Ley N. ${ }^{\circ}$ 30167. Ley que modifica el Decreto Legislativo N. ${ }^{\circ} 1012$, que aprueba la Ley Marco de Asociaciones Público Privadas para la generación de empleo 
productivo y dicta normas para la agilización de los procesos de promoción de la inversión privada (2014). Recuperado del sitio de internet del Diario El Peruano: http://diariooficial.elperuano.pe/normas.

León Almenara, J. P. La línea 2 del metro de Lima avanzó solo el 6\% en un año. (14 de abril de 2017). El Comercio. Recuperado de http://elcomercio.pe/lima/linea-2$\underline{\text { metro-lima-avanzo-6-ano-414411 }}$

Mariluz Laguna, O., Concesionario del aeropuerto Jorge Chávez llevaría a Perú a arbitraje internacional. (13 de junio de 2016). Gestión. Recuperado de http://gestion.pe/economia/concesionario-aeropuerto-jorge-chavez-llevaria-peruarbitraje-internacional-2163055

Resolución de Contraloría N. ${ }^{\circ}$ 273-2014-CG aprueba las Normas Generales de Control. (12 de mayo de 2014). Recuperado de http://foncodes.gob.pe/portal/phocadownload/2014/NGcontrol_gubernamental/R C-273-2014-CG.pdf

Resolución de Contraloría N. ${ }^{\circ}$ 148-2016-CG aprueba la Directiva N. ${ }^{\circ}$ 012-2016CG/GPROD. Emisión del Informe Previo establecido por el literal 1) del artículo $22^{\circ}$ de la Ley $N^{\circ} 27785$. (13 de mayo de 2016). Recuperado del Diario Oficial El Peruano. http://busquedas.elperuano.com.pe/normaslegales/aprueban-ladirectiva-n-012-2016-cggprod-emision-del-info-resolucion-no-148-2016-cg-ydirectiva-no-012-2016-cggprod-1380287-1/

Resolución de Contraloría N. ${ }^{\circ}$ 432-2016-CG aprueba la Directiva N. ${ }^{\circ}$ 017-2016CG/DPROCAL. Control Simultaneo. (03 de octubre de 2016). Recuperado del Diario Oficial El Peruano.

http://www.culturacusco.gob.pe/portal/descargar/directiva017-2016controlsimultneo.pdf

Resolución de Contraloría N. ${ }^{\circ}$ 389-2016-CG aprueba la Directiva N. ${ }^{\circ} 016-2016-$ CG/DPROCAL “Grupo de Control de Inversiones”. (02 de agosto de 2016). Recuperado del Diario Oficial El Peruano. http://busquedas.elperuano.com.pe/normaslegales/aprueban-directiva-n-0162016-cgdprocal-grupo-de-control-resolucion-n-389-2016-cg-1411267-1/ 
Radio Programas del Perú Noticias. Cuánto se invirtió en el Aeropuerto Jorge Chávez? (17 de febrero de 2017). Recuperado de https://www.youtube.com/watch?v=yj7PG76meNw\&feature=youtu.be

Thorne Vetter, A. Thorne (07 de marzo de 2017). Candados a celebración indiscriminada de adendas" con nueva Ley de APP. Gestión. Recuperado de http://gestion.pe/economia/thorne-sobre-nueva-ley-app-se-pondran-candadoscelebracion-indiscriminada-adendas-2183966

Thorne Vetter, A. (29 de marzo 2017). Modifican Reglamento de las Asociaciones Pública Privadas. Perú 21. Recuperado de http:// http://peru21.pe/economia/modifica-reglamento-ley-asociaciones-publicoprivadas- 2275745

Vilcanqui Velásquez, P (2012). Las iniciativas privadas en proyectos de inversión: creatividad, ¿Cuándo limitar y cuándo no?. Revista de Derecho Administrativo, 291- 294.

World Bank Group. (Wed, 2017-02-01). ¿Qué son las asociaciones público privadas? Recuperado de http://ppp.worldbank.org/public-privatepartnership/es/asociaciones-publico-privadas/definicion 


\section{BIBLIOGRAFÍA}

Maraví, M, Harman, D., Huapaya, M., Maraví M., Mendoza, Milagros, y Ruíz A. (2012). Aspectos teóricos y prácticos de las Asociaciones público privadas en el Perú. . Ecb Editores (Eds.) (pp. 1-37). Lima.

Banco Interamericano de Desarrollo. (2015) Asociaciones Público privadas : Implementando soluciones en Latinoamérica y el Caribe (pp 1-15) 


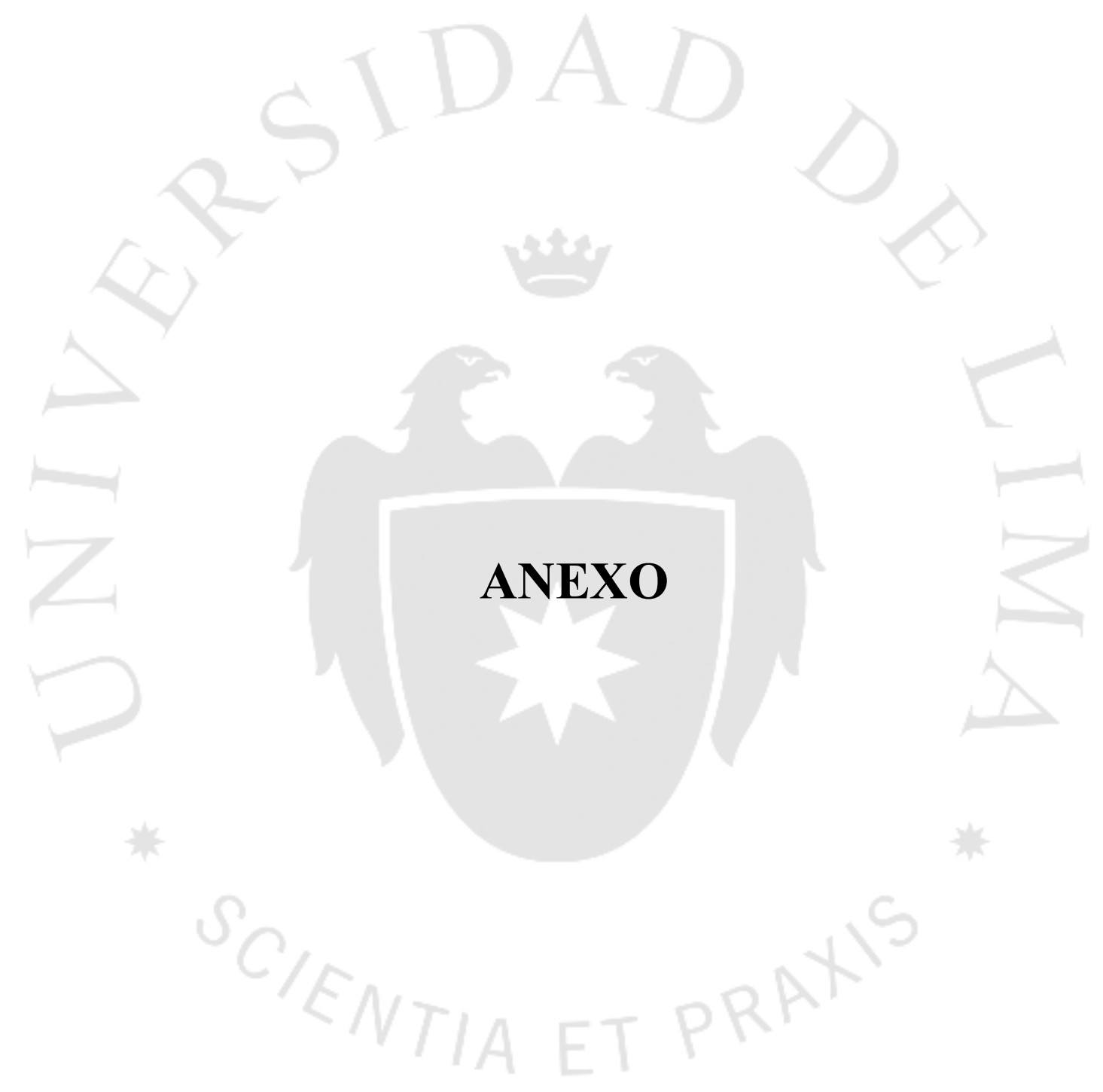


Anexo 1. Procesos Adjudicados en el Período Enero 2008 - MARZO 2017(*) (en millones de dólares)

\begin{tabular}{|c|c|c|c|c|c|c|c|c|}
\hline AÑO ("x) & MES $(* *+1-$ & PROYECTO & SECTOR & ADJUDICATARIO & $\begin{array}{l}\text { PAIS DE ORIGEN DE } \\
\text { ADJUDICATARIO }\end{array}$ & $\begin{array}{l}\text { MONTO DE } \\
\text { TRANSACCIÓI] }\end{array}$ & $\begin{array}{l}\text { INVERSIÓN } \\
\text { ESTIMADA }\end{array}$ & MODALIDAD $F$ \\
\hline 2014 & Jul & $\begin{array}{l}\text { Gestión del Instituto Nacional de Salud del Niño - San } \\
\text { Borja }\end{array}$ & SALUD & $\begin{array}{l}\text { Consorcio Gestora Peruana de Hospitales integrado por Ibérica de Mantenimiento S.A. } \\
\text { sucursal del pera, DokESIM S.LL, Mediterránea de Catering S.L, Sociedad Uni personal y } \\
\text { MedLab Cantellia Colichón S.A.A.C. }\end{array}$ & ESPAÑA-PERÚ & 0 & $\circ$ & COFINANCIADO \\
\hline 2014 & May & Sistema de Telecabinas de Kuélap & TURISMO & $\begin{array}{l}\text { Consorcio Telecabinas Kuélap conformado por las empresas POMAGALSKI S.A.S. e } \\
\text { Ingenieros Civiles y Contratis tas Generales S.A. }\end{array}$ & FRANCIA-PERÚ & o & 18 & COFINANCIADO \\
\hline 2014 & Abr & Aeropuerto Internacional Chinchero - Cusco & TRANSPORTE & $\begin{array}{l}\text { Consorcio Kuntur Wasi, integrado por las empresas Corporación América S.A. y Andino } \\
\text { Investment Holding S.A. }\end{array}$ & ARGENTINA - PERÚ & 0 & 537 & COFINANCIADO \\
\hline 2014 & Mar & $\begin{array}{l}\text { LINEA } 2 \text { Y RAMAL AV. FAUCETT - AV. GAMBETTA DE LA RED } \\
\text { BASICA DEL METRO DE LIMA Y CALLOO }\end{array}$ & TRANSPORTE & 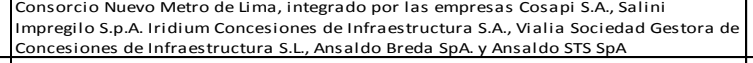 & ESPAÑA - ITALIA - PERÚ & 0 & 5,075 & COFINANCIADO \\
\hline 2013 & Dic & $\begin{array}{l}\text { RED DORSAL NACIONAL DE FIBRA ÓPTICA: COBERTURA } \\
\text { UNIVRSAL NORE, COBERTUR UNIVERSAL SUR Y } \\
\text { COBERTURA UNIVERSAL CENTRO }\end{array}$ & TELECOMUNICACIONES & CONSORCIO TV AZTECA - TENDAI & MÉXICO-COLOMBIA & 0 & 276 & COFINANCIADO \\
\hline 2013 & Dic & $\begin{array}{l}\text { LONGITUDINAL DE LA SIERRA TRAMO 2: CIUDAD DE DIOS- } \\
\text { CAAAAARCA-CHIIE, CAAMMARA-TRUILO Y DV. CHILTEE- } \\
\text { EMPALME PE-3N }\end{array}$ & TRANSPORTE & $\begin{array}{l}\text { Consorcio CONSIERRA TRAMO II conformado por SACYR CONCESIONES SLY } \\
\text { CONSTRUCTORA MALAGA HNOS S.A }\end{array}$ & ESPAÑA-PERÚ & 0 & 552 & COFINANCIADO \\
\hline 2013 & Dic & PROYECTO CHAVIMOCHIC - TERCERA ETAPA & IRRIGACIÓN & $\begin{array}{l}\text { Consorcio Rio Santa - Chavimochic integrado por Odebrecht Participacoes } \mathrm{e} \\
\text { Investimentos S.A., Construtora Norberto Odebrecht S.A. y Graña y Montero S.A.A. }\end{array}$ & PERÚ-BRASIL & 0 & 574 & COFINANCIADO \\
\hline 2011 & abr & $\begin{array}{l}\text { TERMINAL PORTUARIO DE YURIMAGUAS - NUEVA } \\
\text { REFORMA }\end{array}$ & PUERTOS & CONSORCIO PORTUARIO YURIMAGUAS & COLOMBIA-CHILE & 0 & 37 & COFINANCIADO \\
\hline 2011 & feb & 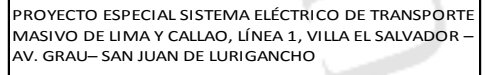 & TRANSPORTE & $\begin{array}{l}\text { CONSORCIO TREN LMA, LINEA } 1 \text { INTEGRADO POR: GRAÑA Y MONTERO S.A. Y FERROVIASS } \\
\text { S.A. }\end{array}$ & PERÚ-ARGENTINA & 0 & 208 & COFINANCIADO \\
\hline 2010 & sep & MAES - SIGUAS II & AGRICULTURA & CONSORCIO ANGOSTURA - SIGUAS: COBRA INSTALACIONES Y SERVICIOS; Y COSAPI & COLOMBIA & $\circ$ & 344 & COFINANCIADO \\
\hline 2010 & sep & SEGUNDO GRUPO DE AEROPUERTOS REGIONALES & TRANSPORTE & CONSORCIO AEROPUERTOS ANDINOS DEL PERÚ & ESPAÑA - PERÚ & 0 & 216 & COFINANCIADO \\
\hline 2009 & ene & $\begin{array}{l}\text { PROGRAMA COSTA SIERRA: NUEVO MOCUPE - CAYALTÍ- } \\
\text { OYOTÚN }\end{array}$ & TRANSPORTE & OBRAINSA (OBRAS DE INGENIERIA S.A.) & PORTUGAL - PERÚ & o & ${ }_{15}$ & COFINANCIADO \\
\hline 2008 & nov & $\begin{array}{l}\text { PROGRAMA COSTA - SIERRA: OVALO CHANCAY - DESVIO } \\
\text { VARIANTE PASAMAYO - HUARAL-ACOS }\end{array}$ & TRANSPORTE & CONALVIAS S.A./INFRACON S.A. & COLOMBIA & $\circ$ & 29 & COFINANCIADO \\
\hline
\end{tabular}

(*) No incluye Venta de Acciones y Activos

(**) Ordenado por fecha de otorgamiento de buena pro.

Fuente y elaboración: Dirección de Promoción de Inversiones - PROINVERSIÓN 